UNIVERSIDADE DE SÃO PAULO

FACULDADE DE ZOOTECNIA E ENGENHARIA DE ALIMENTOS

Danilo Brito Bambil

USO DE PREBIÓTICOS NO DESEMPENHO, NOS PARÂMETROS SANGUÍNEOS E NAS CARACTERÍSTICAS DE CARCAÇA DE BOVINOS NELORE SOB ESTRESSE PELO TRANSPORTE 
Danilo Brito Bambil

\section{USO DE PREBIÓTICOS NO DESEMPENHO, NOS PARÂMETROS SANGUÍNEOS E NAS CARACTERÍSTICAS DE CARCAÇA DE BOVINOS NELORE SOB ESTRESSE PELO TRANSPORTE}

(Versão corrigida)

Defesa de título de mestrado apresentado à Faculdade de Zootecnia e Engenharia de Alimentos da Universidade de São Paulo, como parte dos requisitos para a obtenção do título de Mestre em Ciências do Programa de Pósgraduação em Zootecnia.

Área de Concentração: Qualidade e Produtividade Animal.

Orientador: Prof. Dr. Rodrigo Silva Goulart. 


\section{USO DE PREBIÓTICOS NO DESEMPENHO, NOS PARÂMETROS SANGUÍNEOS E NAS CARACTERÍSTICAS DE CARCAÇA DE BOVINOS NELORE SOB ESTRESSE PELO TRANSPORTE}

Dissertação apresentada à Faculdade de Zootecnia e Engenharia de Alimentos da Universidade de São Paulo, como parte dos Requisitos para obtenção do título de mestre em Ciências.

Área de concentração: Produtividade e Qualidade Animal.

Data da Aprovação:

Banca Examinadora:

Prof. Dr.

Instituição:

Presidente da Banca Examinadora

Prof.(a) Dr.(a):

Instituição:

Prof.(a) Dr.(a):

Instituição:

Prof.(a) Dr.(a):

Instituição: 
Ficha catalográfica elaborada pelo

Serviço de Biblioteca e Informação, FZEA/USP, com os dados fornecidos pelo(a) autor(a)

\section{Bambil, Danilo}

Uso de prebioticos no desempenho, nos parâmetros

B199u sanguíneos e nas daracterísticas de carcaça de bovinos nelore sob estresse pelo transporte. / Danilo Bambil ; orientador Rodrigo Goulart. -Pirassununga, 2021.

$80 \mathrm{f}$.

Dissertação (Mestrado - Programa de Pós-Graduação em Zootecnia) -- Faculdade de Zootecnia e Engenharia de Alimentos, Universidade de São Paulo.

1. Prebióticos. 2. Estresse. 3. Transporte. 4. Desempenho. 5. Nelore. I. Goulart, Rodrigo, orient. II. Título.

Permitida a cópia total ou parcial deste documento, desde que citada a fonte - o autor 


\section{DEDICATÓRIA}

A Deus em primeiro lugar, somente ele sabe o que, quando, onde e como será cada grão em nossa vida.

A minha mãe (in memorian) Haidê Ap. de Mattos Brito e a meu pai Sebastião Bambil, por toda educação.

A meus irmãos Diego Augusto Brito Villalon e Daniel Brito Villalon que desde minha adolescência são meus pilares.

A minha namorada Eduarda Buck Bernardes Guimarães pela dedicação, apoio, confiança, compreensão e amor depositados a mim.

A todos meus amigos que se fizeram presente de alguma forma nessa fase da minha vida. 


\section{AGRADECIMENTOS}

Agradeço primeiramente a Deus por tudo que tem feito em minha vida.

A minha namorada Eduarda Buck Bernardes Guimarães, que sempre esteve ao meu lado, incentivando, mostrando os caminhos e me amparando, independente se o momento era de felicidade ou não. Você foi e é fundamental ao meu lado.

A minha família, Diego, Daniel, Tia Li, Tio Tute, Vó Ni e Neto, que sempre foram minha segunda família.

À Faculdade de Zootecnia e Engenharia de Alimentos da Universidade de São Paulo, pela oportunidade de realização do curso de Mestrado.

O presente trabalho foi realizado com apoio da Coordenação de Aperfeiçoamento de Pessoal de Nível Superior - Brasil (CAPES) - Código de Financiamento 001.

A todos os profissionais que me auxiliaram nessa etapa, Prof. Dr. Saulo da Luz e Silva e Prof.

Dr Eduardo Birgel, em especial a meu orientador Dr. Rodrigo Silva Goulart, pelo conhecimento, paciência, dedicação e profissionalismo o qual me guiou e me ensinou muito para que a cada dia me torne uma pessoa melhor, seja no profissional ou pessoal.

Aos funcionários da FZEA dos setores: fábrica de ração, gado de corte, gado de leite e abatedouro e demais laboratórios. Em especial agradeço aos colaboradores Dione e Ricardinho, sem vocês exatamente nada sairia como o planejado, vocês são mais do que importantes para nós, para os animais e para o setor.

Aos meus amigos de longa e curta data, Henrique, Fábio, Juan, Daniel, Mariane, Bruna, Camylla, Kumeama, Igor, Tales, Douglas e demais da Rep Caipira.

A equipe fantástica de estagiários que tive o prazer de contar, todos sem exceção, vocês foram

formidáveis ao comprometimento com o trabalho. Creio que meu agradecimento seja eterno a cada um de vocês.

A empresa YesSinergy do Brasil pela parceria profissional e a busca em novas tecnologias para melhorar da produção animal. 


\section{RESUMO}

BAMBIL, D. B. Uso de prebióticos no desempenho, nos parâmetros sanguíneos e nas características de carcaça de bovinos nelore sob estresse pelo transporte. 2021. Dissertação de (Mestrado) Faculdade de Zootecnia e Engenharia de Alimentos, Universidade de São Paulo, Pirassununga, 2021.

Bovinos recém-desembarcados no confinamento comumente apresentam elevado nível de estresse, desencadeando alterações comportamentais e fisiológicas, o que gera impacto negativo na saúde e por consequência no desempenho produtivo. Objetivou-se avaliar o efeito da suplementação de diferentes prebióticos sobre a saúde animal, desempenho, parâmetros sanguíneos e nas características de carcaça de bovinos Nelore sob estresse do transporte. Quarenta e oito bovinos Nelore não castrados com peso médio de $380 \mathrm{~kg} \pm 15 \mathrm{~kg}$ foram distribuídos em delineamento inteiramente casualizados contendo 4 tratamentos: TC, dieta sem adição de aditivo; TMON, 25ppm de monensina/dia; TMON Pb1, 25ppm de monensina/dia + 25 gramas de prebióticos/animal/dia: betaglucanas, $300 \mathrm{~g} / \mathrm{kg}$, mananoligossacarídeos, $120 \mathrm{~g} / \mathrm{kg}$ e glucomananos, $420 \mathrm{~g} / \mathrm{kg}$; TMON Pb2, 25ppm de monensina/dia + 25 gramas de prebióticos/animal/dia: 1,3 e 1,6 $\beta$-glucanos fosforilados, 150 $\mathrm{g} / \mathrm{kg}, \quad$ mananoligossacarídeos, $\quad 60 \mathrm{~g} / \mathrm{kg}$, frutooligossacarídeos, $120 \mathrm{~g} / \mathrm{kg}$, galactooligossacarídeos, $72 \mathrm{~g} / \mathrm{kg}$, glucomananos, $210 \mathrm{~g} / \mathrm{kg}$. No dia D0 os quarenta e oito animais foram embarcados em 3 caminhões boiadeiros e transportados por aproximadamente 12 horas, posteriormente os animais ficaram em curral sem acesso a água e alimento até a manhã seguinte. Não foi notado efeito significativo dos tratamentos para as caraterísticas de desempenho, comportamento ingestivo e características de carcaça dos animais no presente estudo. Foi notado efeito para diversas características hematológicas (hemograma e bioquímica) dos animais ao longo do confinamento, principalmente no que se refere ao dia anterior e posterior ao transporte. Ocorreu interação da ureia no sangue dos animais em relação ao tratamento e tempo, sendo notado elevação dessa característica ao final do período experimental. Nas condições do presente estudo, conclui-se que o fornecimento de prebiótico e monensina não alteram as características de desempenho e carcaça, o comportamento ingestivo e os parâmetros sanguíneos dos animais sob efeito de transporte, privação de água e alimento.

Palavras-chave: bem-estar, sangue, transporte, Nelore. 


\begin{abstract}
BAMBIL, D.B. Use of prebiotics on performance, blood parameters, and carcass characteristics of Nellore cattle under transport stress. 2021. (Master's Dissertation) Faculty of Animal Science and Food Engineering, University of São Paulo, Pirassununga, 2021.

Newly disembarked cattle in feedlot facilities commonly have high-stress levels, triggering behavioral and physiological changes, which have a negative impact on health and, consequently, on productive performance. This study aimed to evaluate the effect of supplementation of different prebiotics on animal health, performance, blood parameters, and carcass characteristics of Nellore cattle under transport stress. Forty-eight non-castrated Nellore cattle, with an average body weight of $380 \mathrm{~kg} \pm 15 \mathrm{~kg}$, were distributed in a completely randomized design containing 4 treatments: TC, diet without addition of additive; TMON, 25ppm monensin/day; TMON Pb1, 25ppm monensin/day +25 grams of prebiotics/animal/day: beta-glucans, $300 \mathrm{~g} / \mathrm{kg}$, mannan oligosaccharides, $120 \mathrm{~g} / \mathrm{kg}$ and glucomannans, $420 \mathrm{~g} / \mathrm{kg}$; TMON Pb2, 25ppm monensin/day +25 grams of prebiotics/animal/day: 1.3 and 1.6 phosphorylated $\beta$-glucans, $150 \mathrm{~g} / \mathrm{kg}$, mannan oligosaccharides, $60 \mathrm{~g} / \mathrm{kg}$, fructooligosaccharides, $120 \mathrm{~g} / \mathrm{kg}$, galactooligosaccharides , $72 \mathrm{~g} / \mathrm{kg}$, glucomannans, $210 \mathrm{~g} / \mathrm{kg}$. On day D0, animals were loaded onto 3 cattle trucks and were transported for approximately 12 hours. Later, the animals were kept in a pen without access to water and food until the next morning. There was no significant effect of treatments for ingestive behavior, performance, and carcass traits in the present study. An effect was observed for several hematological characteristics (blood count and biochemistry) of the animals throughout the feedlot, especially with regard to the day before and after transport. There was an interaction for urea in the animals' blood in relation to treatment and time, with an increase in this characteristic at the end of the experimental period. Under the study's condition, it is concluded that the supply of prebiotic and monensin does not alter the performance and carcass traits, ingestive behavior, and blood parameters of animals under the effect of transport, food, and water deprivation.
\end{abstract}

Keywords: blood, Nellore, transport, welfare. 
Lista de Ilustrações

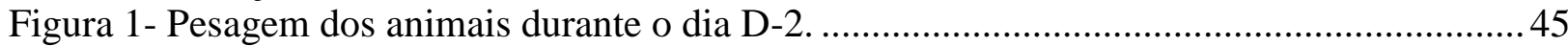

Figura 2- Animais após o desembarque no curral de espera. ............................................... 46

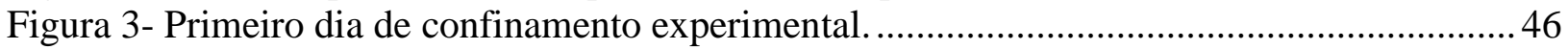

Figura 4- Inclusão de prebiótico por meio do manejo "top dress"........................................... 48

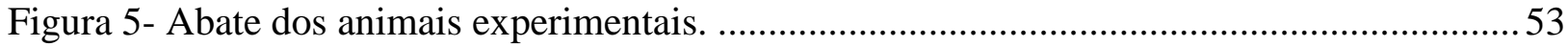

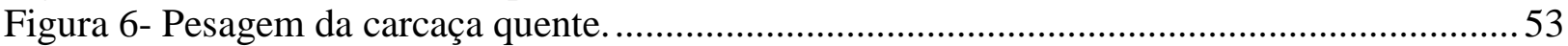

Figura 7- Método para cálculo da área de olho de lombo e espessura de gordura.....................54

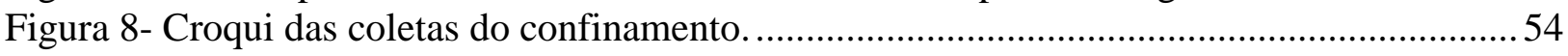

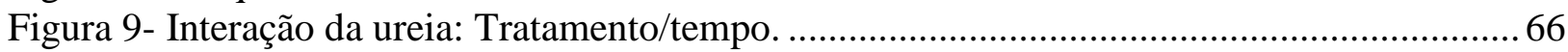


Lista de Tabelas

Tabela 1- Composição da dieta experimental estimada segundo formulação (com base na MS) 47

Tabela 2- Composição química (com base na matéria seca) das dietas de terminação.

Tabela 3 - Desempenho de bovinos Nelore sob estresse por transporte e alimentados sem aditivo, com monensina sódica ou monensina sódica e prébiotico em confinamento. .56

Tabela 4 - Características de carcaça de bovinos Nelore sob estresse por transporte e alimentados sem aditivo, com monensina sódica ou monensina sódica e prébiotico em confinamento. 60

Tabela 5- Comportamento ingestivo de bovinos Nelore sob estresse por transporte e alimentados sem aditivo, com monensina sódica ou monensina sódica e prébiotico em confinamento. 61 Tabela 6- Bioquímica do sangue de bovinos Nelore sob estresse por transporte e alimentados sem aditivos, com monensina sódica ou monensina sódica e prébiotico em confinamento. 62 Tabela 7- Bioquímica do sangue de bovinos Nelore sob estresse por transporte e alimentados sem aditivo, com monensina sódica ou monensina sódica e prébiotico em confinamento. 63 Tabela 8- Hemograma de bovinos Nelore sob estresse por transporte e alimentados sem aditivo, com monensina sódica ou monensina sódica e prébiotico em confinamento. 68 Tabela 9- Hemograma de bovinos Nelore sob estresse por transporte e alimentados sem aditivo, com monensina sódica ou monensina sódica e prébiotico em confinamento. 
Lista de Quadros

Quadro 1 - Valores médios em U/L para a atividade de enzimas hepáticas de bovinos segundo,

Kaneko et al. (1997c) e Morais et al. (2000); Modificado de De Oliveira Paes (2005).

Quadro 2 - Valores normais do leucograma de bovinos segundo Jain (1993); Modificado de De

Oliveira Paes (2005).

52

Quadro 3 - Valores médios de leucócitos em Bovinos da raça Nelore segundo Benesi et al. (2002) e Fagliari et al. (1998). 
1. INTRODUÇÃO GERAL

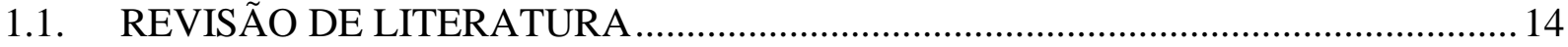

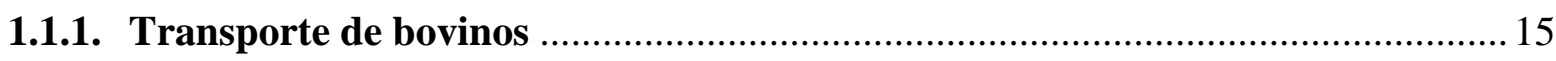

1.1.2. Importância da utilização de aditivos................................................................. 16

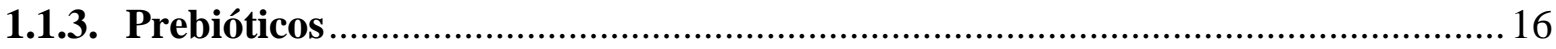

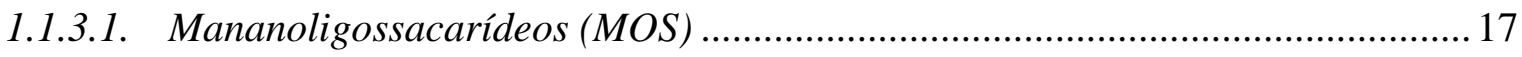

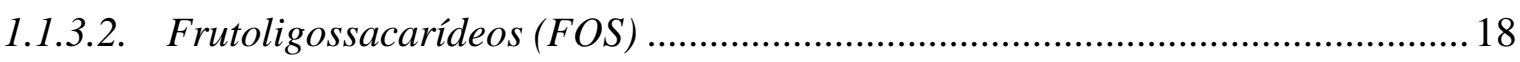

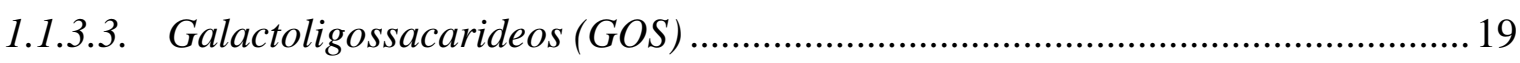

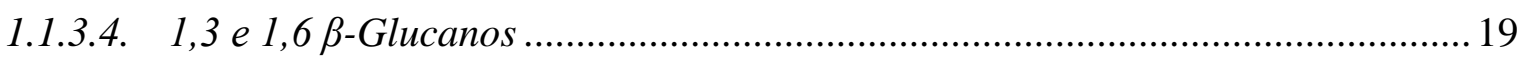

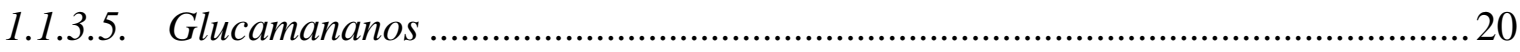

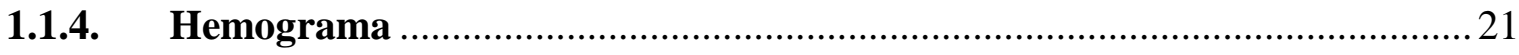

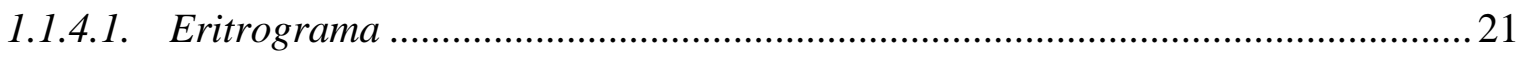



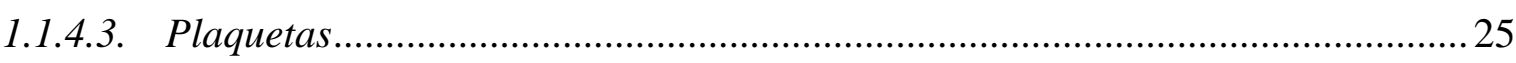

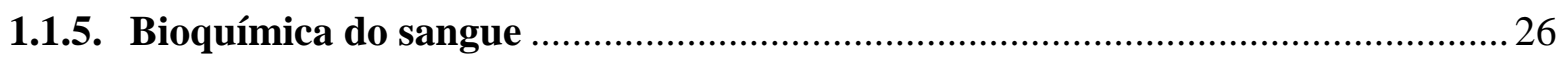

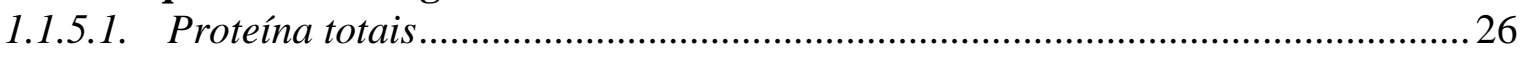

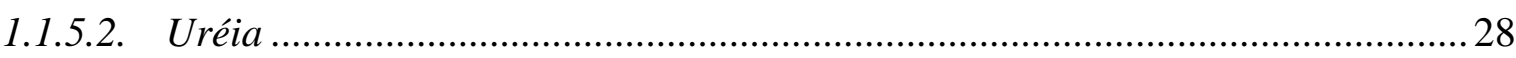

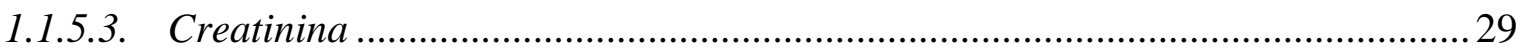



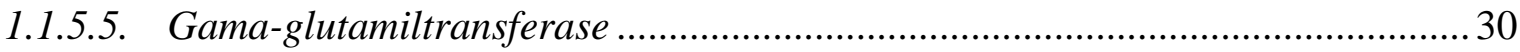

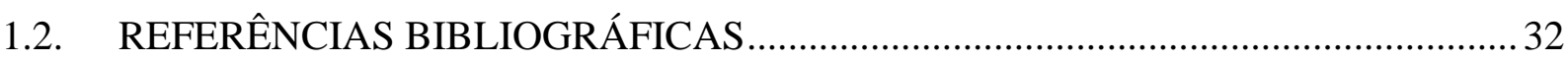

2. CARACTERISTICAS DE DESEMPENHO, CARCAÇA E PARAMETROS

SANGUINEOS DE BOVINOS NELORE SUBMETIDOS AO TRANSPORTE E SUPLEMENTADOS COM MONENSINA E/OU MONENSINA E PREBIÓTICO.......43

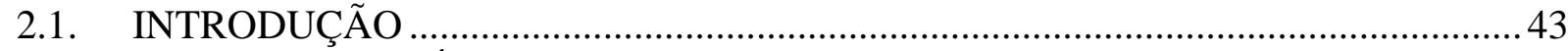



2.2.1. Animais, delineamento experimental e transporte .............................................. 44

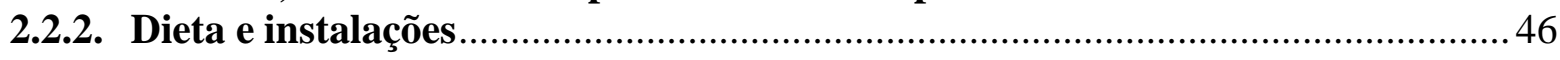

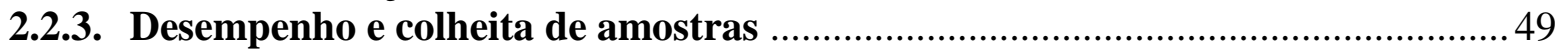

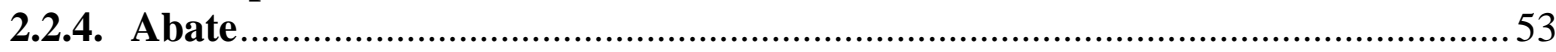

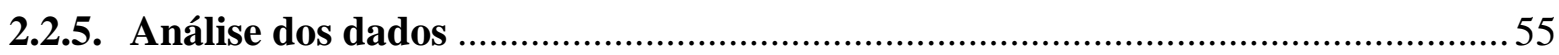

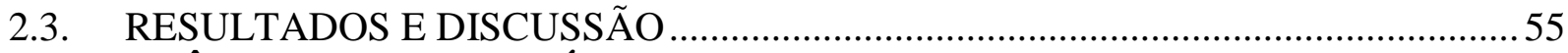

3. REFERÊNCIAS BIBLIOGRÁFICAS .......................................................................... 74 


\section{INTRODUÇÃO GERAL}

Avaliando a pecuária de corte ao redor do mundo, o manejo pré-embarque, o percurso da viagem e o manejo durante o desembarque no confinamento são identificados como um dos principais agentes estressores na vida dos bovinos, promovendo impacto negativo na saúde e consequentemente queda no desempenho desses animais durante o período de engorda (SWANSON E MORROW-TESCH, 2001; CARROLL E FORSBERG, 2007).

Períodos de estresse na vida dos bovinos resultam em aumentos significativos de cortisol provocando uma resposta imune temporária no animal, mais especificamente uma reação inflamatória não específica, que também determina o aumento da concentração de proteínas de fase aguda circulantes. Nesse sentido, os gastos biológicos em respostas pró-inflamatórias e variações nos níveis de proteínas de fase aguda culminam em menores recursos para mantença dos sistemas imunológicos inato e adaptativo (COOKE, 2017).

Melhorias no manejo nutricional durante o período de engorda em confinamento podem ser implementadas dentro da propriedade, visando reduzir perdas econômicas ao produtor (SMITH, 1998). Assim, estudos que visam assegurar a saúde animal e melhorar o desempenho de bovinos utilizando aditivos imunoestimulantes principalmente nas primeiras semanas de engorda em confinamento, tornam-se de extrema importância para a pecuária de corte. Assim, o uso de prebióticos na alimentação de bovinos confinados pode ser uma alternativa interessante no sistema de produção animal.

Prebióticos auxiliam na saúde intestinal dos animais, servindo de substrato para as bactérias benéficas contidas no intestino, excluindo por consequência a colonização de patógenos (GIBSON \& ROBERFROID, 1995). Embora tais produtos não sejam utilizados como substrato na fermentação microbiana intestinal, estes exercem efeito como promotor de crescimento pela melhoria da resistência animal a patógenos entéricos (CUMMINGS E MACFARLANE, 2002).

De acordo com a literatura científica, vários tipos de prebióticos estão disponíveis na indústria de produção animal, tendo em suas composições um único composto, ou vários compostos, em proporções distintas dos seguintes ingredientes: frutooligossacarídeos (FOS), galactooligossacarídeos (GOS), mananooligossacarídeos (MOS) e Beta-glucanos (GIBSON et al., 1995). Importante mencionar que cada prebiótico possui sua própria função e auxilia na melhoria da saúde e do desempenho de animais de produção.

Escassos são os trabalhos científicos no Brasil envolvendo a quantificação e/ou a redução do efeito deletério do transporte, bem como do uso alternativo de aditivos zootécnicos, como o uso de prebióticos, na saúde e no desempenho de bovinos Nelore recém-desembarcados em 
confinamento. Dessa forma, pesquisas dessa natureza poderão contribuir na adoção de novos aditivos zootécnicos, no intuito de melhorar a saúde e o desempenho de bovinos durante o período de engorda em confinamento. Assim, objetiva-se com este trabalho avaliar o efeito da suplementação de diferentes prebióticos sobre o desempenho, as características de carcaça e parâmetros sanguíneos de bovinos Nelore sob estresse pelo transporte.

\subsection{REVISÃO DE LITERATURA}

Mesmo com a grande melhoria feita nos últimos anos envolvendo os métodos de movimentação de bovinos de corte, o transporte é ainda considerado um dos agentes mais estressantes durante toda a vida do animal (GRANDIN et al., 1997; WHITE et al. 2009; CERNICCHIARO et al., 2012b).

De acordo com Swanson e Morrow-Tesh (2001), muitos são os fatores envolvidos durante o processo de transporte de bovinos e que acarretam estresse. Tais fatores envolvem o manejo de pré-transporte, barulho, vibração, o "medo do novo ou inusitado", inversão térmica, reagrupamento social, superlotação de animais, restrição hídrica e alimentar, carregamento e descarregamento, tempo de viagem, condições das estradas, etc.

Quanto maior a distância percorrida e mais diversificada a origem dos animais, maior a variabilidade no desempenho de bovinos durante o processo de engorda, como também, maior a probabilidade de elevar as taxas de morbidade e mortalidade durante as primeiras semanas de confinamento em virtude do desencadeamento de um processo de imunossupressão (RICHESON et al., 2009; CERNICCHIARO et al., 2012a; CERNICCHIARO et al., 2012b). Nesse cenário, são considerados grupos de alto risco, por exemplo, os animais de compra (oriundos de fazendas ou leilões) que viajaram longas distâncias até chegar ao confinamento.

Devido à redução da imunidade ocasionada pelo efeito do estresse da viagem e do longo período de restrição hídrica e alimentar, somado aos desafios enfrentados pelos animais durante o período de adaptação, as primeiras quatro semanas de confinamento torna-se o período mais crítico para a ocorrência de doenças e queda no desempenho do animal (HOLLAND et al., 2010; CERNICCHIARO et al., 2012a; BABCOCK, et al., 2009; CERNICCHIARO et al., 2012c).

Os efeitos do transporte de bovinos são relatados como fator relevante em se tratando de bem-estar animal. Tseimazides (2006) relatou que o transporte desses animais provoca estresse, perda de peso e contusões, podendo inclusive levar animais a óbito quando realizado em condições desfavoráveis. 
Agentes estressores, tais como o processo de embarque, transporte e desembarque em confinamento estimulam a resposta à fase aguda em bovinos, aumentando a concentração plasmática de cortisol, citocinas pró-inflamatórias (fator de necrose tumoral e interleucinas) e proteínas de fase aguda (ARTHINGTON et al., 2005). Esta resposta imune, mesmo sendo um importante componente do sistema inato do animal, tem sido negativamente associada com o desempenho em animais confinados, promovendo diminuição no consumo de matéria seca e consequentemente queda no ganho de peso, principalmente durante os primeiros dias de confinamento (ARAUJO et al., 2010; COOKE, 2017).

Por outro lado, estratégias nutricionais que reduzem à ativação da resposta a fase aguda frente a situações de estresse, principalmente nas primeiras semanas de confinamento, têm demonstrado benefícios na elevação do consumo de matéria seca e no ganho de peso diário, como também, na redução de problemas sanitários durante o período de engorda (ARTHINGTON et al., 2008, citado por COOKE et al., 2017).

Aditivos alimentares alternativos aos antibióticos comumente utilizados em confinamentos denominados de "prebióticos", "parabióticos" ou "substâncias naturais" (também conhecidos por aditivos sem resíduos) tem gerado expectativa no setor de produção animal com vistas a elevar o desempenho, como também, por ser considerados como imunoestimulantes (UYENO et al. 2015).

\subsubsection{Transporte de bovinos}

Nos dias de hoje muito tem se falado no termo estresse e suas consequências econômicas no que se diz respeito ao transporte deficiente dos animais (ROÇA \& SERRANO, 1996). Além disso, a preocupação de países que importam proteína animal e se preocupam com o sofrimento dos animais vem aumentando, como isso, melhores condições de produção, transporte e abates são exigidas (ZANELLA, 2007).

As alterações fisiológicas que ocorrem em bovinos quando em condições adversas, como alteração na temperatura corporal, pressão sanguínea e alterações do ritmo corporal e cardíaco são denominados fatores de respostas ao estresse (JUDJE et al. 1989). Esse processo em cadeia ou mesmo simultâneo é a forma de resposta do animal quando o ambiente se torna desfavorável a sua homeostase (WARRIS et al. 1994).

Os efeitos do transporte de bovinos são relatados como fator relevante em se tratando de bem-estar animal. Apesar da homeostase ser um mecanismo de defesa do próprio animal para com 
agentes estressores, as reações de estresse podem aumentar a susceptibilidade a doenças (BREAZILE, 1998).

\subsubsection{Importância da utilização de aditivos}

Aditivos alimentares são classificados com toda substância, microrganismo ou qualquer produto formulado destinado à alimentação e adicionado intencionalmente na ração como ingrediente, tendo ou não valores nutritivos, melhorando as características dos produtos destinados a alimentação animal e o seu desempenho produtivo (MAPA, 2004).

Segundo Oliveira (2005), apesar de comprovado o benefício do uso de aditivos alimentares, ainda há vários produtos da indústria a serem testados para melhorias do sistema produtivo. Além disso, aspecto econômico e segurança alimentar são fatores importantes na escolha de um aditivo. Antibióticos usados como aditivos zootécnicos muitas vezes apresentam valores economicamente viáveis para os sistemas de produção, entretanto, a segurança desses aditivos tem sido questionada devido ao seu uso rotineiro (ALBINO et. al., 2006).

Partindo do "Princípio da Precaução" a comunidade Europeia tem se posicionado contra o uso indiscriminado de antibióticos na alimentação de animais de produção (monogástricos e ruminantes), mesmo na ausência de dados científicos (LOYOLA et al., 2006). Estudo conduzido por Murarolli (2008) comprovou que a não utilização de antibióticos mostrou-se desvantajoso com relação à conversão alimentar e ganho de peso, demonstrando a importância do fornecimento de aditivos para animais de produção.

Segundo De Blas (1984), a influência sobre a microbiota intestinal causada pelo uso de antibióticos possui um efeito benéfico devido ao controle de infecções subclínicas e potencialização na absorção de nutrientes. Dentre as respostas esperadas de um aditivo alternativo como os prebióticos, quando utilizados para substituição ao antibiótico estão: favorecer o crescimento de organismos benéficos ou diminuir os patogênicos, priorizar a fermentação ácida, melhorar a absorção de nutrientes e a resposta imune humoral (MACARI \& MAIORKA, 2000; FERKET, 2002).

\subsubsection{Prebióticos}

A busca por novas tecnologias que possam aumentar os lucros na cadeia produtiva de alimentos cresce progressivamente nos últimos anos. Mesmo sendo um país de influência global, o Brasil ainda perde com relação a índices de produtividade e precocidade na bovinocultura de 
corte quando comparado a países como os Estados Unidos e a Europa (SALMAN et al., 2003). Dessa forma, novas alternativas que elevam a produtividade em fazendas de gado de corte se fazem necessárias e o uso de aditivos alimentares na dieta de bovinos apresenta-se como importante ferramenta (SALMAN et al., 2003).

Os prebióticos são considerados como compostos orgânicos que não são digeridos na porção anterior do trato gastrointestinal ou indisponíveis para o hospedeiro, como nos monogástricos de maneira geral, mas que estão disponíveis para uma determinada população específica de bactérias tanto intestinais quanto ruminais, sendo estes muitas vezes descritos como alimentos funcionais ou nutracêuticos (SCHREZENMEIR E DE VRESE, 2001). No intestino, os prebióticos, tratam-se de nutrientes limitantes da mucosa do intestino, servem de substrato para bactérias que fazem a fermentação intestinal melhorando assim, a produção de maneira geral (COLLINS E GIBSON, 1999; CRITTENDEN, 1999; BRANNER E ROTH-MAIER, 2006).

Mais especificamente, os prebióticos são conhecidos como ingredientes alimentares, constituídos basicamente por polissacarídeos e oligossacarídeos, que não são digeridos na porção proximal do trato gastrintestinal, principalmente de animais monogástricos (RAI et al., 2013). Nos ruminantes, os prebióticos estimulam o crescimento de diversas bactérias benéficas no rúmen e/ou no intestino cujos metabólitos atuam melhorando o aproveitamento e a digestibilidade dos alimentos (UYENO et al., 2015; ZHANG et al. 2018).

Os produtos da fermentação de prebióticos pelos microrganismos intestinais também atuam como imunomoduladores, elevando a eficiência energética e a digestibilidade da dieta, além de diminuir o pH intestinal ocasionando um efeito de redução de bactérias patogênicas (ROODPOSHTI E DABIRI, 2012).

\subsubsection{Mananoligossacarídeos (MOS)}

Os prebióticos, particularmente os mananoligossacarídeos (MOS) são capazes de produzir uma grande quantidade de respostas benéficas ao hospedeiro. Entre os principais benefícios mencionados na literatura dos prebióticos, destacam-se: melhoria na degradabilidade de nutrientes, tanto no rumem quanto no intestino (MOHAMMED et al., 2013); melhoria no desempenho, alterações no metabolismo e inibição de bactérias ruminais, principalmente as produtoras de lactato como Streptococcus bovis e Lactobacillus sp (SANCHES et al., 2006; KEZAR \&CHURCH, 1979b); maior estabilidade do pH ruminal (DIAZ et al., 2018a); ativação do sistema imune dos animais (LEI et al., 2013; PUKROP et al 2018; DIAZ et al., 2018a). 
Outro fator conhecido dos MOS é o de carrear moléculas tóxicas pelas fezes dos bovinos, ocasionando menor número de lesões da mucosa gastrointestinal e consequentemente, reduzindo a incidência de processos inflamatórios, tendo efeitos benéficos na imunologia. Os MOS estão presentes na superfície externa da parede celular de leveduras (Saccharomyces cerevisiae) e são responsáveis por ativar as respostas de defesas locais e sistêmicas dos animais (VYAS et al., 2014; BROADWAY et al., 2015).

Os MOS são constituídos de uma estrutura complexa de manose fosforilada, beta-glucanos e proteínas, sendo todas substâncias biológicas naturais atuantes como imunoestimulantes, capazes de ativar mecanismos não específicos relacionados à defesa dos animais (KLIS et al., 2002; LI et al, 2011). Segundo Heinrichs et al. (2003) os MOS possuem a capacidade de se ligar de forma competitiva às bactérias Gram-negativas como Escherichia coli e Salmonella spp., impedindo que estas colonizem a trato gastrointestinal dos animais. Ainda, estes autores reportaram efeitos benéficos com a suplementação dos MOS em bezerros, elevando o desempenho, diminuindo o desenvolvimento de bactérias maléficas na parede intestinal de animais e elevando a produção de proteínas séricas ligadas a imunidade, promovendo melhor imunocompetência contra doenças infecciosas (HEINRICHS et al., 2003).

A capacidade ligante do MOS às toxinas foi relatada por Johnson et al. (1997) alegando que essas substâncias ao serem aderidas as moléculas dos MOS passam por todo o trato gastrointestinal sem serem absorvidas pelo hospedeiro. Lei et al. (2013) reportaram que a competência dos MOS de se ligar as toxinas está correlacionada a sua carga positiva presente em sua estrutura, uma vez que as endotoxinas e as micotoxinas apresentam cargas negativas que são atraídas pela força eletrostáticas presente na molécula dos MOS.

Mesmo não estando completamente claro o modo de ação dos MOS, acredita-se que as mananoproteinas possuem grande afinidade de ligação com as lecitinas presentes nas Fimbrias Tipo 1 que se localizam nas superfícies de bactérias patogênicas. Dessa forma, é válida a capacidade do MOS em se ligar a uma grande variedade de microrganismos de forma competitiva evitando a povoação destes no trato digestório (HEINRICHS et al., 2003).

\subsubsection{Frutoligossacarídeos (FOS)}

Os (FOS) e os (MOS) estão entre os compostos mais usados como prebióticos para ruminantes, sendo o segundo encontrado em parede celular de levedura conforme já mencionado e o primeiro, encontrado em plantas como a cebola, o aspargos, a alcachofra, a banana, o alho e a cana-de-açúcar (LI et al. 2011). 
Os FOS são compostos de origem vegetal, sendo comumente chamados de açúcares não convencionais (HARTEMINK et al. 1997). Possuem grande impacto na indústria do açúcar por proporcionarem elevadas características funcionais benéficas ao hospedeiro, como por exemplo, queda no $\mathrm{pH}$ do intestino e redução da contagem de bactérias anaeróbias totais nas fezes, favorecendo a colonização de bifidobactérias (SPIEGEL et al., 1994). Dentre todos os produtos que hoje são utilizados como prebióticos, o que mais tem chamado à atenção são os FOS proveniente da fermentação da sacarose (YUN et al.,1996).

Alguns autores como Lei et al. (2013) e Diaz et al. (2018ab) reforçaram a importância de se conhecer mais a fundo esses mecanismos os quais melhoram a saúde dos ruminantes a partir da nutrição, como por exemplo, a diminuição de efeitos negativos (acidose ruminal) a partir do fornecimento de FOS, que normalmente são oriundas de dietas contendo alta concentração de grãos.

\subsubsection{Galactoligossacarideos (GOS)}

A transgalactosilação da lactose pela ação $\beta$-galactosidase gera os transgalactooligossacarideos (TGOs), essa enzima também apresenta como produto de outra reação (realizada também pela hidrólise da lactose) o produto final na forma de GOS (RABIU et al., 2001; TZORTZIS et al., 2005). A adição de GOS ao substituto do leite anteriormente demonstrado por Quickley et al., (1997) mostrou ter efeitos benéficos no crescimento e na saúde de bezerros leiteiros.

A suplementação de FOS, MOS e GOS podem ser uma alternativa para melhorar o desempenho de crescimento de bezerros no estágio pré ou pós-desmame (CASTRO et al., 2016). Contudo, modificações nas atividades de fermentação microbiana por esses açúcares ainda não foram examinados em detalhes. Além disso, semelhante ao caso dos probióticos, os benefícios do uso de prebióticos se dá em maior quantidade em animais que não estejam saudáveis (HEINRICHS et al., 2009).

\subsubsection{1,3 e 1,6 $\beta$-Glucanos}

Conforme Kim et al. (2006), os $\beta$ - glucanos possuem a capacidade de desencadear uma resposta imune ao hospedeiro ativando seus mecanismos de defesa, sendo reconhecidos como modificadores da resposta biológica apresentando efeitos imunomoduladores. Esses compostos são considerados promotores da ativação do sistema imune inato por beneficiar a prevenção de 
infecções por meio da estimulação de macrófagos e neutrófilos. Os $\beta$-glucanos são considerados como modificadores da resposta biológica no hospedeiro (BROADWAY et al., 2015).

Estudo feito por Rice et al, (2009) com base em citometria de fluxo mostrou que as células M do epitélio (linfócitos cobertos por células epiteliais especializadas conhecidas como Placas de Peyer) possuem a capacidade de absorverem os $\beta$-glucanos fazendo com que eles cheguem à corrente sanguínea.

O reconhecimento de receptores como dectin-1 e o receptor de complemento 3 (CR3), que estão permanentes na superfície de células imunes como macrófagos/monócitos, neutrófilos e células "Natural Killer" dão início a modulação dos $\beta$-glucanos (BROWN et al., 2006). Devido a esse reconhecimento do $\beta$-glucano pelo Dectin-1, um acionamento celular pode reduzir a resposta pró-infamatória, por meio da produção de citocinas anti-inflamatórias (4, 10 e 13) como as interleucinas, que por sua vez atuam sobre os macrófagos ativados, reduzindo outras citocinas (1, 6, TNF- $\alpha$ e o oxido nítrico) tendo importante papel em doenças de caráter inflamatórias como, endotoxemia e sepse (LUHM et al., 2006; PUKROP et al., 2018).

\subsubsection{Glucamananos}

A adição de substâncias nas dietas dos animais afim de controlar as micotoxicoses é comumente realizado, sendo estas capazes de diminuir a absorção de micotoxinas pelo intestino (GALLO et al, 2010). A aflatoxina é uma das micotoxinas que mais causam prejuízos em animais de produção, dentre um dos fatores, pode-se citar as severas lesões hepáticas que levam o animal a perdas produtivas, como diminuição no ganho de peso e na eficiência alimentar (EDRINGTON et al., 1994).

Segundo Yiannikouris et al. (2002) as micotoxinas inibem algumas bactérias ruminais provocando deficiência em seu crescimento e ocasionando diminuição da digestibilidade dos alimentos.

Outro fator que acarreta em prejuízos para a produção animal é a capacidade da aflatoxina em suprimir a resposta imune em caprinos, conforme relatado por Fernadez et al. (1997), comprometendo tanto a imunidade celular como a imunidade humoral (CORRIER, 1991).

Os glucamananos são provenientes de leveduras (Saccharomyces cerevisiae), sendo estes estudados mais assiduamente nas últimas décadas em suínos e aves e poucos trabalhos relatados em ruminantes. (ARAVIND et al., 2003). Rabassa et al. (2010) relataram que o fornecimento de glucamananos para ruminantes que fizeram ingestão de alimentos contaminados com aflatoxina, 
apresentaram melhora quanto a imunidade corroborando com a afirmação de outros autores (FUKUDA et al. 2009).

\subsubsection{Hemograma}

Segundo Jain (1986), o volume sanguíneo corresponde a $10 \%$ do peso do animal, sendo o responsável por efetuar o transporte de substancias, bem como manter a homeostase por meio do carreamento de hormônios, de metabólitos, de nutrientes e gases, de oxigênio e de gás carbônico para os demais tecidos. O sangue é constituído por duas partes, sendo, uma liquida (plasma) e outra sólida (celular) (SCHIMIDT-NIELSEN 1996). A parte sólida é constituída de células como as hemácias, células redondas, bicôncavas anucleadas em mamíferos e nucleadas em aves (MARTINHO, 2012). As hemácias são as células responsáveis pelo transporte de oxigênio aos demais tecidos pela corrente sanguínea (SOUZA \& ELIAS 2006).

Para ser utilizado como ferramenta de avaliação do estado nutricional, os estudos dos constituintes do sangue devem ser explorados visando conhecer os padrões sanguíneos de cada espécie, bem como, os causadores de suas alterações (MORRIS et, al., 1993).

Nas últimas décadas ocorreram aumentos de interesse no desenvolvimento de pesquisas no campo da hematologia veterinária, pois a melhora no aperfeiçoamento das técnicas utilizadas, bem como, o respaldo laboratorial às soluções relativas aos problemas clínicos pertinentes a diversas espécies tem sido muito evidenciado (SILVA, 2010).

Em países onde os animais são criados de maneira extensiva, o animal não possui grande contato com humanos e passa grande parte de sua vida tomando suas próprias escolhas (GRANDIN, 2008). Para a entrada no confinamento, que muitas vezes não é feito no mesmo local de origem, os animais passam por manejos de pré-carregamento, embarque e viagem até o destino de engorda causando níveis elevados de estresse nesses animais (LYLES \& CALVO, 2014). Animais em situações como às acima citadas, podem apresentar queda no consumo de ração, diminuição do ganho de peso e queda da função imunológica pois, um simples manejo até mesmo bem feito e um embarque podem desencadear o processo de estresse (LYLES \& CALVO, 2014).

\subsubsection{Eritrograma}

Segundo Jain (1993), fatores que influenciam os constituintes sanguíneos começaram a ser estudados a partir do desenvolvimento da hematologia clínica veterinária, dentre eles, a idade é o 
principal fator de influência, sendo também observado variações devido ao modo de criação dos animais, a alimentação, o sexo e a raça.

Os eritrócitos (hemácias) são produzidos na medula óssea em resposta à eritropoietina produzida principalmente pelos rins. Eles são responsáveis pelas trocas gasosas, transportando oxigênio e dióxido de carbono em sua estrutura heme (JONES et al., 2007).

O hemograma é normalmente pedido pelo médico veterinário para verificar o estado de saúde do animal ligado a casos de estresse como: desidratação, hemorragias e tratamentos de anemia os quais são causas de alteração do hemograma (LEE et al., 1974; GOMES et al., 2006).

Casos como, problemas hepáticos, super-desidratação ou estresse térmico prolongado, podem reduzir o hematócrito a níveis baixos sendo o animal considerado anêmico (GOMES et al., 2006). Por outro lado, doenças pulmonares ou tumores renais estimulam a produção de eritropoietina elevando o hematócrito em até $50 \%$, tornando o sangue mais viscoso, diminuindo seu fluxo e por consequência promovendo a distensão de capilares e pequenos vasos, levando a trombose e distúrbios no sistema nervoso central (THRALL, 2007). Animais com hematócrito acima de $60 \%$ atingem estado de policitemia (relativa ou absoluta), em que há mudança da viscosidade sanguínea, diminuição da perfusão e comprometimento da oxigenação de vários tecidos (SOTO et al., 2008; BUSH, 2004).

A avaliação do sangue permite o diagnóstico de doenças de difícil detecção, sendo o eritrograma o exame que nos permite uma interpretação de uma possível alteração do quadro eritrocitário causado por anemia ou mesmo desidratação (COWELL \& TYLER, 2002). O exame mencionado acima avalia de forma quantitativa e qualitativa as hemácias, além de ser de grande serventia auxiliando na determinação de diagnósticos, prognósticos e da eficácia terapêutica de diversas enfermidades que possam alterar o quadro eritrocitário (DELFINO et al., 2012). Cowell \& Tyler (2002) e Silva et al. (2011) mostraram que a contagem total e o grau de maturação eritrocitária são possivelmente observados por meio do eritrograma em várias espécies animais.

O eritrograma compreende a contagem do número total de hemácias $(\mathrm{He})$, volume globular ou hematócrito (HT), concentração de hemoglobina (Hb), volume corpuscular médio (VCM) e concentração de hemoglobina corpuscular média (CHCM) (LOPES, 2007).

As hemácias possuem tempo de vida útil muito curto (maturação de 4-5 dias em bovinos, duração de vida de 160 dias), por isso, há necessidade de serem repostas frequentemente (TRHALL, 2007). Esse processo de produção e liberação são frequentes e ocorrem na medula óssea, processo que tem o nome de Eritropoiese. Em animais saudáveis, o número de células é regulado dentro de um limite muito estreito, de modo que haja hemoglobina suficiente para promover a oxigenação adequada dos tecidos, mas que as células vermelhas não fiquem tão 
concentradas no plasma a ponto de impedir o fluxo sanguíneo devido ao aumento de sua viscosidade (RIBEIRO, 2005; REAGAN et al., 2011; SILVA, 2011).

A redução da massa de eritrócitos circulantes é causada devido ao desequilíbrio entre a taxa de perda e/ou destruição e a taxa de produção dos mesmos pela medula óssea, comumente em animais anêmicos tais números reduzidos são encontrados (REED et al., 2004). Variáveis ambientais podem apresentar evidentes variações dos elementos constituintes do hemograma, interferindo na adaptabilidade dos animais (VIANA et al., 2002).

Segundo Ribeiro (2005) toda vez que o animal é acometido por medo, excitação, dor ou exercício rigoroso há uma mobilização eritrocitária do baço para a corrente sanguínea. Com isso, há um aumento da massa eritrocitária na corrente sanguínea, fenômeno denominado policitemia. Outro fator que pode contribuir para o aumento dos eritrócitos é a diminuição do volume plasmático ou redistribuição eritrocitária (desidratação) (SOTO, 2008).

O VCM é o índice do tamanho médio das hemácias, utilizado para classificá-las em três categorias: normocíticas, macrocíticas ou microcíticas. Quando uma hemácia tem tamanho e coloração normal ela é chamada de normocítica e normocrônica respectivamente (TRHALL, 2007). As hemácias são bicôncavas, apresentam coloração central mais pálida e coloração um pouco mais escura na periferia (KERR, 2003). Ao microscópio, as hemácias têm coloração acidófila (afinidade pelos corantes ácidos que dão coloração rósea) e são desprovidos de núcleo com algumas exceções para aves, répteis e anfíbios.

Conforme relatou Bezerra et al. (2008), o estresse por calor de longa duração pode reduzir o número de eritrócitos e o volume globular, pois os mesmos são reduzidos à medida que o animal diminui a ingestão de água e comida, levando a uma hemoconcentração. Já Earley et al. (2013) descreveram que os parâmetros hematológicos mesmo alterados por consequência de bovinos estressados por transporte, estavam dentro dos limites de referência. Tais resultados também foram encontrados por Brunel et al. (2018) em que estudaram o efeito de diferentes manejos préembarque e tempos de transporte em bovinos Nelores nos parâmetros sanguíneos e relataram mudanças hematológicas, mas dentro dos limites considerados normais para a espécie.

Gomes et al., (2006) relataram que a unidade do volume relativo dos eritrócitos em uma amostra de sangue é quantificada como hematócrito, expresso em porcentagem por volume de células vermelhas no sangue. Normalmente é solicitado como parte do hemograma para verificar se o animal recuperou a hidratação ou monitorar casos de hemorragias. Bovinos que permaneceram 19 horas transportados em caminhões, apresentaram aumentos das medidas sanguíneas relacionadas a desidratação (volume corpuscular médio e hemoglobina) quando 
chegaram para o desembarque (BERNARDINI ET AL., 2012). De acordo com Herz \& Steinhaut, 1978), animais que sofrem com estresse prolongado tendem a apresentar redução do hematócrito.

\subsubsection{Leucograma}

Os glóbulos brancos possuem importante papel na defesa imunológica sendo constituídos por subpopulações: granulócitos (neutrófilos, eosinófilos e basófilos) e agranulócitos (monócitos e linfócitos). A produção e maturação dos leucócitos ocorrem na medula óssea, já os linfócitos em tecidos linfoides. A população de leucócitos no sangue é baixa quando comparada a população total de células sanguíneas sendo que os glóbulos brancos sofrem grande flutuação (Kraft et al., 2005).

A população de neutrófilos podem ser consideradas como marginal ou circulatória. A população marginal é fixada em células endoteliais dos vasos sanguíneos, enquanto que a circulatória acompanha o fluxo sanguíneo. $\mathrm{O}$ aumento da quantidade de neutrófilos ocorre por meio da ação de glicocorticoides, podendo eles ser endógenos ou exógenos, causando mobilização dos neutrófilos marginais da microvasculatura, bem como a indução do aumento da liberação de reserva dessas células da medula óssea (JAIN, 1993). Com o aumento da pressão sanguínea, bem como a velocidade do fluxo sanguíneo, essa população marginal de neutrófilos acaba por se destacar e se juntar a população circulante, tendo como consequência desse aumento de pressão sanguínea o aumento da quantidade de leucócitos presentes no sangue (WEBB JL et al., 2011).

Geralmente as diferentes subpopulações de neutrófilos, em banda ou segmentados, podem ser diferenciados em uma contagem completa de leucócitos, pois em laboratório é realizada separadamente uma contagem total de leucócitos, uma diferencial relativa do sangue e uma diferencial absoluta do sangue (KRAFT et al., 2005; WOOD et al., 2011).

Em bovinos um fator de diminuição da população leucocitária é a idade, sendo que em bezerros recém-nascidos a população de granulócitos é superior à de linfócitos (GRÜNDER, HD, 2006).

Durante o primeiro mês de vida do bezerro é observado uma diminuição do número total de leucócitos, neutrófilos e linfócitos quando comparado ao nascimento, posteriormente aos três meses, a porcentagem de linfócitos aumentam em $80 \%$ com relação a população total de leucócitos circulantes, com decréscimo em níveis inferiores quando adultos, mas mesmo assim continua sendo a maior população encontrada (MOHRI et al., 2007). Quando adultos os bovinos apresentam uma proporção de neutrófilos e linfócitos na ordem de 1:2 sendo que a população de 
eosinófilos é considerada baixa para esses animais quando comparada as demais espécies de animais domésticos (TORNQUIST et al., 2010).

Quando o animal está em repouso, grande parte dos leucócitos se encontram sequestrados nos capilares sanguíneos tendo seus níveis mais baixos quando mensurados nessa fase. Por outro lado, em situações de excitação, observa-se a liberação de epinefrina fazendo com que haja aumento da pressão sanguínea e linfática causando o retorno dos mesmos para o sangue periférico elevando o número de leucócitos (leucocitose fisiológica), porém sem manifestação de doenças (NORTHINGTON, 2000).

Cole et al. (1997) relata que a leucocitose fisiológica acompanha mudanças características de neutrofilia, de linfocitose, bem como, contagens com variação numérica de monócitos e poucos eosinófilos. Posteriormente Taylor (2000) acrescenta que com a indução de leucocitose fisiológica a partir da epinefrina o quadro em que esses animais se enquadram seria uma leucocitose neutrofílica, tendo também aumento de linfócitos e monócitos.

As designações de leucograma incluem diagnóstico e avaliações de saúde além de monitoramento de ações terapêuticas, porém, dificilmente é possível chegarmos a conclusões somente com relação a contagem de leucócitos (KRAFT et al., 2005). A avalição feita com leucogramas sequenciais, ou seja, várias coletas com o decorrer dos dias, seria de maior valia uma vez que, ajudam a estabelecer um prognostico, pois, o reestabelecimento do leucograma a níveis normais indicariam um possível sinal favorável junto a melhoria clinica dos animais (GRÜNDER, HD, 2006).

\subsubsection{Plaquetas}

As plaquetas ou também chamados de trombóticos, nada mais são do que fragmentos plasmáticos anucleares de megacariócitos e desempenham papel essencial na homeostasia como a coagulação de ferimentos. A regulação da liberação de plaquetas parece estar correlacionada com o hormônio chamado trombopoietina, o qual tem sua ação na regulação do desenvolvimento dos megacariócitos a partir de células-tronco, sendo a concentração desse hormônio inversamente proporcional ao número de plaquetas. Ainda há incerteza sobre a fonte de trombopoietina, mas acredita-se que seja proveniente do endotélio vascular, fígado ou fibroblastos (REBAR et al., 2003). As plaquetas bovinas possuem volume plaquetário médio de 4 a 4,8 femtolitros, com cerca de $35 \%$ sendo sequestradas no baço adentrando à circulação devido a uma resposta de estresse ou fuga, uma vez que há liberação de epinefrina (RUSSELL, 2010). 
Em suma, o exame com contagem de plaquetas pedido pelo médico veterinário pode ser indicado em casos de suspeita de hemorragia grave ou tendência de aumento de sangramento. Esse exame junto a sinais clínicos de vermelhidão (equimose, petéquias), sangue na urina, fezes ou em foças nasais, são eficientes para diagnóstico de hemorragias antes de uma evolução mais severa (THOMAS, 2010). O número total de plaquetas é influenciado pela quantidade de produção, consumo, sequestro e perda (RUSSELL, 2010).

Trombocitose é o nome dado quando se tem um aumento de plaquetas na corrente sanguínea podendo ser primária ou reativa, no caso de doenças mieloproliferativas (leucemia), ou secundária a outras doenças como inflamações causadas por agentes externos que causam algum trauma, como por exemplo um corte (STOKOL, 2010).

Por outro lado, quadro de trombocitopenia em bovinos, que é a diminuição do número de plaquetas, não apresentam hemorragias espontâneas a não ser que números fiquem inferiores ao intervalo de 10.000 a 50.000 células/ $\mu$ L (THRALL, 2007). Tal diminuição do número de plaquetas pode se dar por três motivos, sendo esse, falhas: na produção, na distribuição ou na destruição. Na produção, podem ser causados por má formação das células hematopoiéticas primordiais, substituição da medula normal e trombocitopoese ineficaz. O aumento da destruição de plaquetas pode ser proveniente de distúrbios imunológicos ou ainda doenças não imunológicas. Assim como esses distúrbios, problemas na distribuição de plaquetas ou decorrentes de uma transfusão podem ocasionar trombocitopenia (REBAR et al., 2003).

\subsubsection{Bioquímica do sangue}

Como reflexo da situação metabólica dos animais, a composição bioquímica do sangue apresenta elevada relação quanto a avaliação de lesões teciduais, mal funcionamento de órgãos, desafios nutricionais e fisiológicos à adaptação e desafios metabólicos (GONZÁLEZ et, al., 2003). Além de ser utilizado para a avaliar o estado de saúde dos animais, os parâmetros sanguíneos são comumente utilizados como indicador de estresse (GONZÁLEZ ET AL., 2000).

A leitura de resultados do perfil bioquímico é bastante complexa sendo aplicadas tanto a rebanhos como a um único indivíduo, pois, o controle sanguíneo é manipulado por vários mecanismos que depende de inúmeros fatores como raça, idade, sexo, manejo, clima e estado fisiológico do animal (GONZÁLEZ \& SCHEFFER 2003).

\subsubsection{Proteína totais}


O exame hematológico é bastante utilizado na medicina veterinária para detectar doenças ocultas, além de, direcionar tomadas de decisões clinicas para casos isolados de um animal ou um grupo de animais (WEISS \& PERMAN, 1992).

Em ruminantes a resposta leucocitária é diferente quando comparada a demais espécies, isso devido a esses animais possuírem um compartimento limitado de reserva leucocitária na medula óssea (COLE et al., 1997; TAYLOR, 2000). Esse achado faz, com que neutrófilos imaturos apareçam rapidamente na corrente sanguínea em casos de inflamação aguda (KANTEK et al., 2005).

Para contribuir com o diagnóstico de ruminantes, a avaliação de proteínas como albumina, a globulina e o fibrinogênio junto ao leucograma se torna de maior valia, uma vez que, somente a contagem de leucócitos frente a doenças inflamatórias possui ampla variabilidade (ECKERSALL \& CONNER, 1988; SUTHERLAND \& WHITNEY, 1995).

As proteínas plasmáticas, são sintetizadas principalmente no fígado, sendo a funcionalidade hepática e o estado nutricional do animal os principais responsáveis pela taxa de síntese das mesmas. Quando se fala em proteínas plasmáticas, as principais são a albumina, as globulinas e o fibrinogênio, que possuem função abrangente como transporte de nutrientes, participação direta no sangue em processos como coagulação, pressão e viscosidade, transporte de metabólitos, hormônios e produtos de excreção (GONZÁLEZ et al., 2000).

A proteína plasmática mais abundante é a albumina, por ter um tamanho grande, habitualmente ela é retirada dos capilares, porém, perdida rapidamente em situações de injurias teciduais. A razão albumina:globulina podem apresentar uma razão diferenciada, uma vez que a hipoalbuminenia combinada com globulina normal faz com que essa razão (A/G) seja diminuída. Já um quadro de hipoalbuminemia aumentada junto a uma hipoglobulinemia também aumentada, são traduzidos como uma razão normal, pois não há alteração na proporção de Albumina/Globulina (KANEKO, 1989; DUNCAN et al., 1994).

Para dimensionar e obter a concentração de globulina total é realizado a diferença entre proteína total e albumina, logo, erros analíticos consequentes podem acarretar em acúmulo de erro e promover resultados equivocados a respeito da concentração exata de globulina (MEYER e HARVEY, 2004). Segundo Chorfi et al., (2004), para que não ocorra erros em relação a interpretação dos resultados, é necessário uma padronização e cuidados na coleta de amostras (local da coleta e método de avaliação principalmente), assim possíveis falhas no processo são minimizados diminuindo a chance de erros de interpretação em animais normais (CHORFI et al. 2004). 
Quadros de hipoglobulinemia e hiperglobulinemia são observados em hiper-hidratação e desidratação respectivamente. A hipoglobulinemia, que é a perda de globulina, ocorre em situações como hemorragias, exsudação excessiva, falhas de transferência ou defeito na síntese de imunoglobulinas (MEYER e HARVEY, 2004). Quanto ao aumento de globulinas a hiperglobulinemia provoca síntese de proteínas e é encontrada em decorrência de respostas inflamatórias e injurias teciduais (THOMAS, 1998).

\subsubsection{Uréia}

A ureia é sintetizada no fígado a partir da amônia no ciclo de Krebs-Henseleit, sendo ela uma molécula hidrossolúvel (KANEKO, 2008). A reciclagem da ureia é um mecanismo vital para o animal, sendo responsável por conservar compostos nitrogenados dietético e corporal mantendo níveis desejáveis de aminoácidos nos tecidos. Porém essa reciclagem segundo Van Soest (1994) tem um gasto de energia pelo animal na ordem de $12 \mathrm{kcal} / \mathrm{g}$ de nitrogênio. Essa reciclagem se dá quando há excesso de amônia sendo absorvida pela parede ruminal, a qual cai na corrente sanguínea chegando ao fígado e sendo convertida novamente em ureia.

Grande parte do nitrogênio utilizado pelos microrganismos é proveniente da amônia, pois as bactérias que constituem a microbiota ruminal tem bastante eficácia no processo de assimilação, sendo determinados pela disponibilidade de carboidratos fermentáveis (LAPIERRE e LOBLEY, 2001).

O aumento da quantidade de amônia produzida no rúmen e consequente aumento de ureia plasmática se dá de várias formas, uma delas seria por meio de dietas com excesso de proteína ou fontes de nitrogênio não proteico e deficiência de energia. Outra forma é a redução da capacidade dos microrganismos em utilizar os compostos nitrogenados para a síntese de proteína, causando caquexia ou hemorragia no interior do trato gastrointestinal (GONZÁLEZ e SILVA, 2006). González et al. (2000) relata que quando o animal excreta nitrogênio não somente há gasto de energia, mas os níveis de amônia e ureia além de reduzir o apetite do animal, causam queda da eficiência produtiva. Fatores que diminuem as concentrações de ureia no sangue seriam provenientes de esteroides, uma redução no catabolismo proteico ou uma severa insuficiência hepática (DORETTO et al., 1996).

Wittwer et al. (1993) reportaram que como parte do perfil metabólico animal, a concentração de ureia sanguínea tem sido bastante empregada como indicador de metabolismo proteico, uma vez que, há uma proporção entre ureia sintetizada no fígado e amônia produzida no rúmen sendo relacionada principalmente com os níveis proteicos da ração e relação 
energia/proteína em dietas. $\mathrm{O}$ mesmo autor relatou que dentre os vários distúrbios acometidos no animal, o distúrbio renal é uma causa de alteração da concentração de ureia no sangue.

De maneira geral, a ureia é produzida quando a dieta é rica em proteína e os aminoácidos ultrapassam a necessidade do animal para síntese proteica ou quando o animal passa por um jejum prolongado, sendo as proteínas celulares usadas como fonte de energia para o corpo (Nelson \& Cox, 2005).

\subsubsection{Creatinina}

A creatinina $(\mathrm{CK})$ deriva do catabolismo da creatina presente no tecido muscular, é um metabolito que desempenha o papel de armazenar energia no músculo na forma de fosfocreatina, tendo uma degradação diária constante. Como é uma reação não enzimática e irreversível ocorrendo somente via renal, seus níveis indicam a taxa de filtração dos rins e, se aumentados, uma deficiência na funcionalidade destes órgãos, tornando um parâmetro confiável e de grande ajuda para análise de funções hepáticas (GONZÁLEZ e SCHEFFER, 2002; GONZÁLEZ e SCHEFFER 2003). Diferente da ureia, a excreção urinária de creatinina parece não variar conforme o teor de proteína bruta na dieta (VALADARES et al., 1997; RENNÓ et al., 2000). A creatinina, no entanto, depende igualmente da ureia quanto a taxa de filtração glomerular (TFG), via de regra, uma redução dessa taxa causa aumento da concentração sérica de creatinina (MEYER et al., 1995).

Diversos autores fizeram experimentos com bovinos da raça Nelore, sendo observados

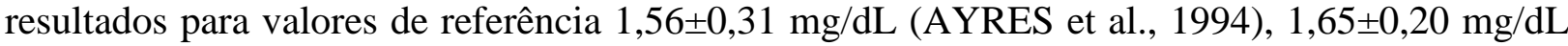

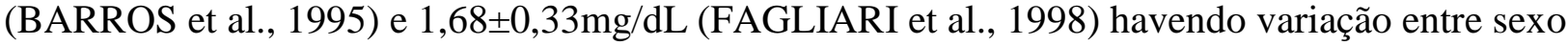

e idade dos animais. $\mathrm{O}$ aumento das concentrações de CK se mostra independente da duração de transporte, uma vez que, Van de Water et al. (2003) e Bernardini et al. (2012) que movimentaram animais em média de 2 horas e meia e 19 horas respectivamente, obtiveram lesões teciduais e diminuição do bem estar dos indivíduos devido a fadiga do transporte.

\subsubsection{Aspartato-aminotransferase}

A aspartato aminotransferase (AST) é uma enzima encontrada no citoplasma e na mitocôndria se fazendo presente em várias partes do corpo, como fígado, músculo cardíaco e esquelético, hemácias e intestino. Em doenças de origem crônicas, que danificam o fígado, independente da etiologia (hepatopatias), o exame laboratorial pode apresentar elevação da AST 
no soro, pois, sempre que ocorrer um aumento da permeabilidade da membrana do hepatócito a AST também é aumentada (MEYER et al., 1992). Nos bovinos, é comum a atividade enzimática crescente em casos de necrose hepática, doença do músculo branco e inanição (COLES, 1984). Thrall (2007) ressaltou que em ruminantes a elevação da AST pode não se dar somente por via de hepatopatias, mas também por lesão muscular, fazendo-se necessário associar a dose de creatinocinase pois essa é somente músculo-específica; assim, se há concentrações elevadas de ambas as enzimas indicam musculo lesionado, enquanto atividades elevadas de AST na presença de CK normal indicam provável distúrbio em células do fígado (THRALL, 2007).

Nicoletti et al. (1981) relatou que a raça de bovinos tem influência sobre os valores de AST. Otto et al. (1992) ressaltou que em experimento com animais da raça Nelore valores de AST

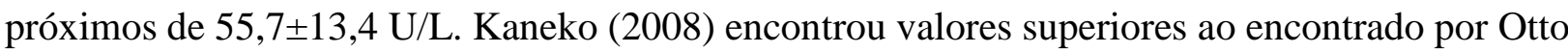
(1992), sendo estes possuindo valores de referência entre 78 a 132 U/L. Uetake et al. (2009) encontrou em vacas cruzadas, aumento nas concentrações de AST após sofrerem estresse de manejo tradicional ou após 72 horas de transporte, mostrando que o exercício intenso desses animais tem influência sobre a concentração dessa enzima, porem se mantendo dentro dos valores de referência para a espécie.

\subsubsection{Gama-glutamiltransferase}

A GGT é uma enzima, associada a membrana de numerosos tecidos (MEYER et al., 1995) como fígado, rins, pâncreas e intestino (TENNANT, 1997). Grande parte da GGT celular está nas células tubulares renais e no epitélio dos ductos biliares (KRAMER \& HOFFMANN, 1997); encontrada principalmente no tecido biliar, e, portanto, um bom indicador de colestase intra ou extra-hepática (ANDERSON, 1992; KERR, 2003). Porém, a colestase provoca aumento na atividade sérica desta enzima, em todas as espécies (MEYER et al., 1995; KRAMER \& HOFFMANN, 1997), com melhor utilidade diagnóstica que a fosfatase alcalina (FA), em equinos e ruminantes (MEYER et al., 1995), em razão do amplo intervalo de referência da FA nessas espécies (DUNCAN et al., 1994); mesmo que a GGT esteja presente em muitos tecidos, elevações na sua atividade sérica são observadas primariamente em desordens hepáticas (TENNANT, 1997).

Ha ausência de dados para grande parte das análises do trabalho de pesquisa devido a categoria de animais escolhidas, reforçando ainda mais a importância do projeto. De Oliveira Paes (2005) reportou maiores valores de GGT em bezerros Nelore recém desmamados e sob estresse de viagem por aproximadamente 4 horas, quando comparado com animais sem o efeito do transporte (22 e 17,5 U/L, respectivamente). 
A interpretação do perfil bioquímico é complexa tanto aplicada a rebanhos quanto a indivíduos, devido a mecanismos que controlam o nível sanguíneos de vários metabólitos e devido, também, a grande variação desses níveis em função de fatores como raça, idade, estresse, dieta, nível de produção leiteira, manejo, clima e estado fisiológico (GONZÁLEZ \& SCHEFFER 2003). 


\subsection{REFERÊNCIAS BIBLIOGRÁFICAS}

ALBINO L.F.T.; FERES F.A.; DIONIZIO M.A.; ROSTAGNO H.S.; VARGAS JR. J.G.; CARVALHO D.C.O.; GOMES P.C.; COSTA C.H.R. Uso de prebióticos à base de mananoligossacarídeo em rações para frango de corte. Revista Brasileira de Zootecnia, Viçosa, v.35, n.3, p.742-749, 2006.

ANDERSON, V. N. Veterinary gastroenterology. 2. ed., Philadelphia: Lea \& Febiger, p. 873, 1992.

ARAUJO, D.B.; COOKE, R.F.; HANSEN, G.R.; STAPLES, C.R.; ARTHINGTON, J.D. Effects of rumen-protected polyunsaturated fatty acid supplementation on performance and physiological responses of growing cattle after transportation and feedlot entry. Journal of Animal Science, v. 88, p. 4120-4132, 2010.

ARAVIND, K. L.; PATIL, V. S.; DEVEGOWDA, G.; UMAKANTHA, B.; GANPULE, S. P. Efficacy of esterified glucomannan to counteract mycotoxicosis in naturally contaminated feed on performance and serum biochemical and hematological parameters in broilers. Poultry Science, v. 82, n. 4, p. 571-576, 2003.

ARTHINGTON, J.D.; SPEARS, J.W.; MILLER, D.C. The effect of early weaning on feedlot performance and measures of stress in beef calves. Journal of Animal Science, v. 83, p. 933-939, 2005.

ARTHINGTON, J.D.; QIU, X.; COOKE, R.F.; VENDRAMINI, J.M.B.; ARAUJO, D.B.; CHASE JR, C.C.; COLEMAN, S.W. Effects of preshipping management on measures of stress and performance of beef steers during feedlot receiving. Journal of Animal Science, v. 86, p. 2016-2023, 2008.

AYRES, M. C. C. Eritrograma de zebuínos (Bos indicus, Linnaeus 1758) da raça Nelore, criados no Estado de São Paulo: Influência de fatores etários, sexuais e do tipo racial. 141f. Dissertação (Mestrado) - Faculdade de Medicina Veterinária e Zootecnia, Universidade de São Paulo, São Paulo, 1994.

BABCOCK, A.H.; WHITE, B.J.; DRITZ, S.S.; THOMSON, D.U.; RENTER, D.G. Feedlot health and performance effects associated with the timing of disease treatment. Journal of Animal Science, v. 87, p. 314-327, 2009.

BARROS FILHO I. R. Contribuição ao estudo da bioquímica clínica em zebuínos da raça Nelore (Bos indicus, Linnaeus 1758) criados no Estado de São Paulo. 1995. 133 f. Dissertação (Mestrado) - Faculdade de Medicina Veterinária e Zootecnia, Universidade de São Paulo, São Paulo, 1995.

BENESI, F. J.; COSTA, J. N.; BIRGEL, E. H.; D`ANGELINO, J, L.; AYRES, M. C. C.; FILHO, I. R. B. Leucograma padrão de bovinos da raça Nelore (Bos indicus). Influência de fatores sexuais. Veterinária Notícias, v.8, n.1, p.59-66, 2002.

BERNARDINI D.; GERARDI G.; PELI A.; NANNI COSTA L.; AMADORI M.; SEGATO S. The effects of different environmental conditions on thermoregulation and clinical and hematological variables in long-distance road-transported calves. Journal Animal Science, 90, pp. 1183-1191, 2012.

BEZERRA, L. R.; FERREIRA, A. F.; CAMBOIM, E. K. A.; JUSTINIANO, S. V.; MACHADO, P. C. R.; GOMES, B. B. Perfil hematológico de cabras clinicamente sadias criadas no cariri paraibano. Revista Ciência e Agrotecnologia, Lavras, v. 32, n. 3, p.955960, 2008. 
BODERA, P. Influence of prebiotics on the human immune system (GALT). Recent Patents on Inflammation and Allergy Drug Discovery. Allergy Drug Discov. 2:19-153, 2008 .

BRANNER G.R.; ROTH-MAIER D.A. Influence of pre-, pro-, and synbiotics on the intestinal availability of different B-vitamins. Archives of Animal Nutrition 60: 191-204, 2006.

BREAZILE, J.E. The physiology of stress and relationship to mechanisms of disease and therapeuties. Veterinary Clinics of North America: Food Animal Practice, v.4, n.3, p.441-478, 1988.

BROADWAY, P.R.; CARROLL, J.A.; SÁNCHEZ, NCB. Live Yeast and Yeast Cell Wall Supplements Enhance Immune Function and Performance in Food-Producing Livestock: A Review'. Microorganisms, vol. 3, pp. 417-427, 2015.

BROWN, G.D. 'Dectin-1: A signalling non-tlr pattern-recognition receptor', Nature Reviews Immunology, vol.6, pp.33-43, 2006.

BRUNEL H.S.S.; DALLAGO B.S.L.; ALMEIDA A.M.B.; ASSIS A.Z.; CALZADA R.J.B.; ALVARENGA A.B.B.; MENEZES A.M.; BARBOSA J.P.; LOPES P.R.; GONZÁLEZ F.H.D.; MCMANUS C.; BROOM D.; BERN F.E.M. Hemato-biochemical profile of meat cattle submitted to different types of pre-loading handling and transport times. International Journal of Vetererinary Science and Medicine 6, 90-96, 2018.

BUSH, B.M. Interpretação de resultados laboratoriais para clínicos de pequenos animais. 1 ed. São Paulo: Roca, p. 93, 2004.

CARROLL, J.A.; FORSBERG, N.E. Influence of stress and nutrition on cattle immunity. Veterenary Clinics Food Animal Practice, v. 23, p. 105-149, 2007.

CASEWELL M.; FRIIS C.; MARCO E.; MCMULLIN P.; PHILLIPS I. The European ban on growth-promoting antibiotics and emerging consequences for human and animal health. Journal of Antimicrobial Chemotherapy 52, 159-161, 2003.

CASTRO, J. J.; GOMEZ, A.; WHITE, B. A.; MANGIAN, H. J.; LOFTEN, J. R.; AND DRACKLEY, J. K. Changes in the intestinal bacterial community, short-chain fatty acid profile, and intestinal development of preweaned Holstein calves. 1. Effects of prebiotic supplementation depend on site and age. Journal Dairy Science; 99 (12):9682-702, 2016.

CERNICCHIARO, N.; WHITE, B.J.; RENTER, D.G.; BABCOCK, A.J.; KELLY, L.; SLATTERY, R. Associations between the distance traveled from sale barns to comercial feedlots in the United States and overall performance, risk of respiratory disease, and cumulative mortality in feeder cattle during 1997 to 2009. Journal of Animal Science, v. 90, p. 1929-1939, 2012a.

CERNICCHIARO, N.; WHITE, B.J.; RENTER, D.G.; BABCOCK, A.J.; KELLY, L.; SLATTERY, R. Effects of body weight loss during transit from sale barns to comercial feedlots on health and performance in feeder cattle cohorts arriving to feedlots from 2000 to 2008. Journal of Animal Science, v. 90, p. 1940-1947, 2012b.

CERNICCHIARO, N.; RENTER, D.G.; WHITE, B.J.; BABCOCK, A.H.; FOX, J.T. Associations between weather conditions during the first 45 days after feedlot arrival and daily respiratory disease risks in autumn-placed feeder cattle in the United States. Journal of Animal Science, v. 90, p. 1328-1337, 2012c. 
CHORFI, Y.; LANEVSCHI-PIETERSMA, A.; GIRARD, V.; TREMBLAY, A. Evaluation of variation $\mathrm{n}$ serum globulin concentrations in dairy cattle. Veterinary Clinical Pathology, Davis, v.33, n.3, p.122-127, 2004.

COLE, D.C.; ROUSSEL, A.J.; WHITNEY, M.S. Interpreting a bovine CBC: Evaluation the leukon and acute-phase proteins. Veterinary Medicine, London, v.92, n.5, p.470-478, 1997.

COLES, E. H. Patologia clínica veterinária. 3. ed. São Paulo: Manole. 566p, 1984.

COLLINS D.M.; GIBSON G.R. Probiotics, prebiotics, and synbiotics: approaches for modulating the microbial ecology of the gut. American Journal of Clinical Nutrition 69: 1052S-1057S, 1999.

COOKE, R. F. Nutritional and management considerations for beef cattle experiencing stress-induced inflammation. The Professional Animal Scientist, 33, 1- 11, 2017.

CORRIER, D. E. Mycotoxicosis: mechanisms of immunosuppression. Veterinary Immunology and Immunopathology, v. 30, n. 1, p. 73-87, 1991.

COWELL, R.; TYLER, R. Diagnostic citology and hematology of the horse. 2nd ed. Misouri: Mousby, 2002.

CRITTENDEN RG. Prebiotics. In: Tannock GW (ed.) Probiotics: A Critical Review. Wymondham, UK: Horizon Scientific Press Backlist Books, pp. 141-156, 1999.

CUMMINGS, J. H., MACFARLANE, G. T. Gastrointestinal effects of prebiotics. The British Journal of Nutrition. 87:145-151, 2002.

DE BLAS, C. Alimentación del conejo. Mundi Prensa, Madrid, España, 215 pp, 1984.

DELFINO L.J.B.; SOUZA B.B.; DA R.M.M. \& SILVA W.W. Efeito do estresse calórico sobre eritrograma de ruminantes. Revista Agropecuária Cientifica no Semiárido. v. 8, n. 2, p. 01-07, abr - jun, 2012.

DIAZ, T.G.; BRANCO, A.F.; JACOVACI, F.A.; JOBIM, C.C.; BOLSON, D.C.; DANIEL, J.L.P. Inclusion of live yeast and mannan-oligosaccharides in high grain-based diets for sheep: Ruminal parameters, inflammatory response and rumen morphology. Plos One, 13(2), e0193313, 2018a.

DIAZ, T.G.; BRANCO, A.F.; JACOVACI, F.A.; JOBIM, C.C.; DANIEL, J.L.P.; BUENO, A.V.I.; RIBEIRO, M.G. Use of live yeast and mannan-oligosaccharides in grainbased diets for cattle: Ruminal parameters, nutrient digestibility, and inflammatory response. Plos One, 13(11), e0207127, 2018b.

DORETTO, J. S. Influência do tempo e da temperatura de estocagem sobre a estabilidade de alguns constituintes do soro sanguíneo de bovinos. Jaboticabal, 1996. 61p. (Dissertação de Mestrado). Faculdade de Ciências Agrárias Veterinárias da UNESP Jaboticabal, SP, 1996.

DUNCAN, J.R.; PRASSE, K.W.; MAHAFFEY, E.A. Veterinary Laboratory Medicine: Clinical Pathology. 3rd ed. Ames, EUA: Iowa State University Press, 300p, 1994.

EARLEY B.; DRENNAN M.; O'RIORDAN E.G. The effect of road transport in comparison to a novel environment on the physiological, metabolic and behavioural responses of bulls. Research in Veterinary Science 95, 811-818, 2013.

ECKERSALL, P.D; CONNER, J.G. Bovine and canine acute phase proteins. Veterinary Research Communication, Netherlands, n.2-3, v.12, p.169-178, 1988. 
EDRINGTON, T. S.; HARVEY, R. B.; KUBENA, L. F. Effect of aflatoxin in growing lambs fed ruminally degradable or escape protein sources. Journal of Animal Science, v. 72, n. 5, p. 1274-1281, 1994.

FAGLIARI, J. J.; McCLENAHAN, D.; EVANSON, O. A.; WEISS, D. J. Changes in plasma protein concentrations in ponies with experimental alimentary laminitis. AM. Journal of Veterinary Research, Schaumburg, v.59, n.10, p.1234-1237, 1998.

FERKET, P.R. Manutenção da saúde intestinal em um mundo sem antibióticos. In: RONDA LATINOAMERICANA DA ALLTECH, 13., 2003, Campinas. Anais... Campinas: ALLTECH, 2003. p.26-39.

FUKUDA, E. K.; VASCONCELOS, A. F. D.; MATIAS, A. C.; BARBOSA, A. M.; DEKKER, R. F. H.; SILVA, M. L. C. Polissacarídeos de parede celular fúngica: purificação e caracterização. Semin: Ciências Agrárias, v. 30, n. 1, p. 117-134, 2009.

GALLO, A.; MASOERO, F. In vitro models to evaluate the capacity of different sequestering agents to adsorb aflatoxins. Italian Journal of Animal Science, v. 9, n. 21, p. 109-116, 2010.

GIBSON, G.R.; ROBERFROID, M.B. Dietary modulation of the human colonic microbiota: Introducing the concept of prebiotics. Journal of Nutrition. 125:1401-1412, 1995.

GOMES, K. R.; SANTOS, M. G. C.; FRANCO, D. F.; PIRES, R. B.; SILVA, M. G. D; NEVES, M. F.; BASSANI-SILVA, S. Avaliação do hematócrito e da proteína plasmática em sangues hemodiluidos. Revista Eletrônica de Medicina Veterinária. Ano III, n. 7, 2006.

GONZÁleZ, F.H.D.; DUR, J.W.; FINTANELI, R.S. Perfil Metabólico em Ruminantes: seu uso em nutrição e doenças nutricionais. Gráfica UFRGS, Porto Alegre, 2000.

GONZÁLEZ, F. H. D.; SCHEFFER, J. F. S. Perfil sanguíneo: ferramenta de análise clínica, metabólica e nutricional. AVALIAÇÃO METABÓLICO-NUTRICIONAL DE VACAS LEITEIRAS POR MEIO DE FLUIDOS CORPORAIS, 2002, Gramado. 29 Congresso Brasileiro de Medicina Veterinária. Porto Alegre: Gráfica da Universidade Federal do Rio Grande do Sul, 2002.

GONZÁLEZ, F. H. D.; SCHEFFER, J. F. S. Perfil sanguíneo: ferramenta de análise clínica, metabólica e nutricional. In: I SIMPÓSIO DE PATOLOGIA CLÍNICA VETERINÁRIA DA REGIÃo SUL DO BRASIL, Porto Alegre. Anais... Porto Alegre: UFRGS. p. 73-87, 2003.

GONZÁLEZ, F.H.D.; SILVA, S.C. Introdução a bioquímica clínica veterinária. 2 ed. Porto Alegre: Editora da UFRGS. 358p, 2006.

GRANDIN, T. Assessment of stress during handling and transport. Journal of Animal Science, v. 75, p. 249-257, 1997.

GRANDIN, T., DEESING, M. Humane Livestock Handlin, $1^{\text {st }}$ edition (Storey Publishing, North Adams), 2008

GRÜNDER, H.D. Krankheiten der Kreislauf Organe und des Blutes (Doenças dos órgãos circulatórios e do sangue). In: Innere Medizin und Chirurgie des Rindes (Medicina interna e cirurgia de gado), ed. Dirksen, G, Gründer, HD, Stöber, M, 5 ed., Pp. 159 270. Parey, Berlim, Alemanha. Em alemão, 2006. 
HARTEMINK, R.; VANLAERE, K.M.J.; ROMBOUTS, F.M. Growth of enterobacteria on fructo-oligosaccharides. Journal of Applied Microbiology, Wageningnen, v.383, p.367-374, 1997.

HEINRICHS, A.J.; JONES, C.M.; HEINRICHS, B.S. Effects of Mannanoligosaccharides or antibiotics in neonatal diets on health and growth of dairy calves, Journal Dairy Science, vol.86, pp.4064-4069, 2003.

HERZ, A.; STEINHAUT, D. The reaction of domestic animal to heat stress. Animal Research Development, [S.1.], n. 7, p. 738, 1978.

HOLLAND, B.P.; BURCIAGA-ROBLES, L.O.; VANOBERBEKE, D.L.; SHOOK, J.N.; STEP, D.L.; RICHARDS, C.J.; KREHBIEL, C.R. Effect of bovine respiratory disease during preconditioning on subsequent feedlot performance, carcass characteristics, and beef attributes. Journal of Animal Science, v. 88, p. 2486-2499, 2010.

JAIN, N.C. Schalm's veterinary hematology. 4 th ed. Philadelphia (PA): Lea; Febiger; p.1221, 1986.

JAIN, C.N. Essential of veterinary hematology. Philadelphia: Lea \& Febiger. p 417, 1993.

JOHNSON, P.J.; CASTEEL, S.W.; MESSER, N.T. 'Effect of feeding deoxynivalenol (vomitoxin) - contaminated barley to horses', Journal of veterinary diagnostic investigation, vol.9, pp.219-221, 1997.

JONES, M.L.; ALLISON, R.W. Evaluation of the ruminant complete blood cell count. Veterinary Clinics Food Animal Practice, v. 23, p. 377-402, 2007.

JUDJE, M.; EBERLE, E.; FORREST, J.; HEDRICK, H.; MEKEL, R. Principles of meat science. Ed. Kendall/Hunt, Iowa, U.S.A., 351p, 1989.

KANEKO, J.J. Clinical biochemistry of domestic animals. 4. ed., London: Academic Press, 932 p, 1989.

KANEKO, J. J.; HARVEY, J. W.; BRUSS, M. L. Clinical biochemistry of domestic animals. 6th ed. San Diego: Academic Press. 932p,1997c.

KANEKO, J. J.; HARVEY, J. W.; BRUSS, M. L. Clinical biochemistry of domestic animals. 5th ed. San Diego: Academic Press. 916p, 2008.

KANTEK, C.E.; NAVARRO, K.G. Manual de hematologia veterinária. 2.ed. São Paulo: Varela. 206p, 2005.

KERR M.G. Exames Laboratoriais em Medicina Veterinária - Bioquímica e Hematologia. 2 Ed. São Paulo: Roca, 2003.

KEZAR, W.W.; CHURCH, D.C. Effect of thiopeptin and sodium bicarbonate on the preventionof lactic acidosis induced in sheep. Journal of Animal Science, v.49, n. 5, p. 1396-1402, $1979 \mathrm{~b}$.

KIM, S.Y.; SONG, H.J.; LEE, Y.Y.; CHO, K.H.; ROH, Y.K. Biomedical issues of dietary fiber $\beta$-glucan. Journal Korean of Medical Science, vol.21, pp.781-789, 2006.

KLIS, F.M.; MOL, P.; HELLINGWERF, K., BRUL, S. Dynamics of cell wall structure in Saccharomyces cerevisiae, FEMS Clinical Microbiology Reviews, vol.26, pp.239-256, 2002. 
KRAFT W.; DURR U.M. Klinische Labordiagnostik in der Tiermedizin Clinical laboratory diagnostics in veterinary medicine, 6th ed. Schattauer, Stuttgart, Germany. In German, 2005.

KRAMER, J.W.; HOFFMANN, W.E. Clinical enzymology. In: KANEKO, J. J. Clinical biochemistry of domestic animals. 5.ed. San Diego: Academic Press. Cap.12, p.303-315, 1997.

LALLE`S J.P.; BOSI P.; SMIDT H.; STOKES C.R. Nutritional management of gut health in pigs around weaning. Proceedings of the Nutrition Society 66, 260-268, 2007.

LAPIERRE, H.; LOBLEY, G.E. Nitrogen recycling in the ruminant: a review. Journal of Dairy Science, v.84 (Supl. E), E223- 236, 2001.

LEE, J.A; ROUSSEL J.D.; BEATTY J.F. Effect of temperature season on bovine adrenal cortical function, blood cell profile, and milk production. Journal of dairy Science, Champaign, v. 59, n. 1, p. 104-108, 1974.

LEI, C.L; DONG, G.Z.; JIN L.; ZHANG S.; ZHOU J. Effects of dietary supplementation of montmorillonite and east cell wall on lipopolysaccharide adsorption, nutrient digestibility and growth performance in beef cattle. Livestock Science, vol.158, pp.57-63, 2013.

LI, G.H.; LING, B.M.; QU, M.R.; YOU, J. M.; SONG, X.Z. Effects of several oligosaccharides on ruminal fermentation in sheep: an in vitro, Revue Medicine Veterinary, vol.162, pp.192-197, 2011.

LOPES, S.T.A; BIONDO, W.A; SANTOS, A.P. Manual de Patologia Clínica Veterinária. 3.ed. Santa Maria: UFSM / Departamento de clínica de pequenos animais, 2007. 107 p.

LOYOLA, V.R; PAILE, B.J.A. Utilização de aditivos em rações de bovinos: Aspectos regulatórios e de segurança alimentar. In: Anais... $8^{\circ}$ Simpósio sobre Nutrição de Bovinos - Minerais e Aditivos para bovinos. 2006.

LUHM, J.; LANGENKAMP, U.; HENSEL, J.; FROHN, C.; BRAND, J.M.; HENNIG, H.; RINK, L.; KORITKE, P.; WITTKOPF, N.; WILLIAMS, D.L.; MUELLE, A. $\beta-(1 \rightarrow 3)$-Dglucan modulates DNA binding of nuclear factors $\kappa \mathrm{B}$, AT and IL-6 leading to an antiinflammatory shift of the IL-1 $\beta / \mathrm{IL}-1$ receptor antagonist ratio. BMC Immunology, London, v 7, n.1, p.5, 2006.

LYLES, J.L.; CALVO-LORENZO, M.S.; Bill, E. Kunkle Interdisciplinary Beef Symposium: Practical developments in managing animal welfare in beef cattle: What does the future hold? Journal Animal Science, 92, 5334-5344, 2014.

MACARI, M.; MAIORKA, A. Função gastrintestinal e seu impacto no rendimento avícola. In: CONFERÊNCIA APINCO 2000 DE CIÊNCIA E TECNOLOGIA AVÍCOLAS, Campinas, 2000. Anais... Campinas: Fundação Apinco de Ciência e Tecnologia Avícolas, 2000. p.1.61-174.

MAPA. Ministério da agricultura Pecuária e Abastecimento. Instrução Normativa n.13, de 30 de novembro de 2004. Regulamento Técnico sobre Aditivos para Produtos Destinados à Alimentação Animal, segundo as boas práticas de fabricação, contendo os procedimentos sobre avaliação da segurança de uso, registro e comercialização, constante dos anexos desta instrução normativa. Brasília, 2004.

MARTINHO, F. Blood transfusion in birds. Revista Lusófona de Ciência e Medicina Veterinária. v 5, p 1-30, 2012. 
MCEWEN S. A.; FEDORKA-CRAY P.J. Antimicrobial use and resistance in animals. Clinical Infectious Diseases, Volume 34, Issue Supplement_3, June 2002, Pages, p 93106, 2002.

MEYER, D. J.; COLES, E.; RICH, L. J. Veterinary Laboratory medicine. Philadelphia: W.B. Saunders. 350 p, 1992.

MEYER, D. J.; COLES, E. H.; RICH, L. J. Medicina de laboratório veterinária: interpretação e diagnóstico. São Paulo: Roca. 308p, 1995.

MEYER, D.J.; HARVEY, J.W. Veterinary laboratory medicine: interpretation \& diagnosis. 2 ed. Philadelphia: Sauders, p351, 2004.

MOHAMMED, H.H.; EL-SAYED, BM \& MA, A. Effects of Commercial Feed Additives on Performance, Economic Efficiency, Blood Metabolites and Some Maintenance Behaviour in Goats', Journal of Veterinary Science \& Medicine Diagnosis, vol. 2, p 27, 2013.

MOHRI, M.; SHARIFI, K.; EIDI, S. Hematologia e bioquímica sérica de bezerros da raça Holandesa: mudanças relacionadas à idade e comparação com a composição do sangue em adultos. Research in Veterinary Science 83: 30 de - 39, 2007.

MORAIS M.G.; RANGEL J.M.; MADUREIRA J.S.; SILVEIRA A.C. Variação sazonal da bioquímica clínica de vacas aneroladas sob pastejo contínuo de Brachiaria decumbens. Arquivo Brasileiro de Medicina Veterinária e Zootecnia. 52:98-104, 2000.

MORRIS, D. D.; LARGE, S. M. Alterações no leucograma. In: SMITH, B. P. Tratado de medicina interna de grandes animais. São Paulo: Manole, v.1, p.437-456, 1993.

MURAROLLI, V. D. A. Efeito de prebióticos, probióticos e simbióticos sobre o desempenho, morfologia intestinal e imunidade de frangos de corte. 101p. Dissertação (Mestrado em Medicina Veterinária) Universidade de São Paulo - USP, Pirassununga, 2008.

NELSON, D. L.; COX, M. M. Lehninger principles of biochemistry. 3.ed. New York: Worth Publishers, 1119p 2005.

NICOLETTI, J. L. M.; KOHAYAGAWA, A.; GANDOLFI, W.; IAMAGUTI, P; QUINTANILHA, A. M. N. P. Alguns teores de constituintes séricos e hemograma em vacas da raça gir, Holandês Preto e Branco e Mestiças (Girolanda), na região de BotucatuSP. Arquivos da Escola Superior de Veterinária do Estado de Minas Gerais UFMG, Belo Horizonte, v. 33, n. 1, p. 19-30, 1981.

NORTHINGTON, W. Hematology: leukocytes and their responses, 2000.

OLIVEIRA, M.V.M.; LANA, R.P.; JHAM, G.N.; PEREIRA, J.C.; PÉREZ, J.R.O.; VALADARES FILHO, S.C. Influência da monensina no consumo e na fermentação ruminal em bovinos recebendo dietas com teores baixo e alto de proteína. Revista Brasileira de Zootecnia, v.34, n.5, p.1763-1774, 2005.

OTTO, F.; IBANEZ, A.; CABALLERO, B.; BOGIN, E. Blood profile of Paraguayan cattle in relation to nutrition, metabolic state, management and race. Isr. J. Vet. Med., v. 47, n. 3, p. 91-9, 1992.

PUKROP, J.R; BRENNAN, K.M; FUNNELL, B.J; SCHOONMAKER, J.P. Effect of a Hydrolyzed Mannan and Glucan Rich Yeast Fraction on Performance and Health Status of Newly received Feedlot Cattle, Journal of Animal Science, vol.96, p 3955-3966, 2018. 
QUIGLEY, J.D. III; DREWRY J.J.; MURRAY L.M.; IVEY S.J. Body weight gain, feed efficiency, and fecal scores of dairy calves in response to galactosyl-lactose or antibiotics in milk replacers. Journal Dairy Science. 80:1751-1754, 1997.

RABASSA, V. R.; SCHWEGLER, E.; GOULART, M. A.; LOPES, M. S.; HOFFMANN, D. A. C.; LISBOA, F. P.; VENDRAMIN, L.; ROLL, V. F. B.; DIAZ, G. J.; DEL PINO, F. A. B.; CORRÊA, M. N. Parâmetros metabólicos de ovelhas submetidas a dietas contendo aflatoxina e zearalenona com adição de glucomanano modificado. Brazilian Journal of Veterinary Research and Animal Science, v. 47, n. 1, p. 67-73, 2010.

RABIU, B. A.; JAY, A. J.; GIBSON, G. R.; RASTALL, R. A. Synthesis and fermentation properties of novel galacto-oligosaccharides by $\beta$-galactosidases from Bifidobacterium species. Applied and Environmental Microbiology, Washington, v. 67, n. 6, p. 25262530, 2001.

RAI, V.; YADAV, B.; LAKHANI, G.P. 'Application of Probiotic and Prebiotic in Animals Production: A Review', Environment \& Ecology, vol.31, pp.873 - 876, 2013.

REAGAN, W.S.; ROVIRA, A.I.; DENICOLA, D. Atlas de hematologia veterinária espécies domésticas e não domesticas comuns. Edição 1, pg. 108, 2011.

REBAR, A.H; MACWILLIAMS, P.S; FELDMAN, B.F; METZGER, F.L; POLLOCK, R.V.H; ROCHE, J. Guia de hematologia para cães e gatos. 1 ed., São Paulo: Roca, p. 133-156, 2003.

REED, S.M.; BAYLY, W.M.; SELLON, C. Equine Internal Medicine. 2 nd ed. St Louis (MO): Saunders, 2004.

RENNÓ, L.N.; VALADARES, R.F.D.; VALADARES FILHO, S.C. et al. Concentração plasmática de uréia e excreções de uréia e creatinina em novilhos. Revista Brasileira de Zootecnia, v.29, p.1235-1243, 2000.

RIBEIRO, M.D. Parâmetros hematológicos de potros da raça Crioula suplementados com um hematínico. 52f. Dissertação (Mestrado em Clínica Veterinária) - Universidade Federal de Santa Maria, Santa Maria, RS. 2005.

RICHESON, J.T.; KEGLEY, E.B.; GADBERRY, M.S.; BECK, P.A.; POWELL, J.G.; JONES, C.A. Effects of on-arrival versus delayed clostridial or modified live respiratory vaccinations on health, performance, bovine viral diarrhea vírus type I titers, and stress and imune measures of newly received beef calves. Journal of Animal Science, v. 87, p. 2409-2418, 2009.

ROÇA, R.O.; SERRANO, A.M. Operações de abate de bovinos. Revista Nacional da Carne, v. 228, p. 48-50, 1996.

ROODPOSHTI, P.M.; DABIRI, N. Effects of probiotic and prebiotic on average daily gain, fecal shedding of Escherichia Coli, and immune system status in newborn female calves. Asian-Aust. Journal Animal Science 25:1255-1261, 2012

RUSSELL, K.E. Cinética plaquetária e avaliação laboratorial de trombocitopenia. In: Schalm's veterinary hematology, ed. Weiss, DJ, Wardrop, KJ, 6 ${ }^{\mathrm{a}}$ ed., Pp. 576 - 585. Wiley, Ames, IA, 2010.

SALMAN, A.K.D. Polimorfismo e expressão gênica da lepina em bovinos superprecoces. Botucatu, 49p. Tese, Faculdade de Medicina Veterinária e Zootecnia, Universidade Estadual Paulista, 2003. 
SANCHES, A.L.; LIMA, J.A. de F.; FIALHO, E.T.; MURGAS, L.D.S.; ALMEIDA, E.C. de; VIEIRA NETO, J.; FREITAS, R.T.F. de. Utilização de probiótico, prebiótico e simbiótico em rações de leitões ao desmame. Ciência e Agrotecnologia, v.30, p.774-777, 2006.

SCHIMIDT-NIELSEN, K. Fisiologia animal: adaptação e meio ambiente. 5ed. São Paulo: Santos. p 546, 1996.

SCHREZENMEIR J AND DE VRESE M. Probiotics, prebiotics, and synbioticsapproaching a definition. American Journal of Clinical Nutrition 73 (Suppl.): 354s361s, 2001.

SILVA, E.M.N.; SOUZA, B.B.; SOUSA, O.B.; SILVA, G.A.; FREITAS, M.M.S. Avaliação da adaptabilidade de caprinos ao semiárido através de parâmetros fisiológicos e estruturas do tegumento. Revista Caatinga, Mossoró, v. 23, n. 2, p. 142-148, abr.-jun. 2010.

SILVA, H. I. S. B. Contribuição para o estudo do hemograma do cavalo puro sangue lusitano. 78f. Dissertação de Mestrado- Curso de Pós-graduação em Medicina Veterinária, Universidade Lusófona de Humanidades e Tecnologias, 2011.

SMITH, R.A. Impacto f disease on feedlot performance: A Review. Journal of Animal Science, v. 76, p. 272-274, 1998.

SOTO, J. C. H., et al. Policitemia e eritrocitose em animais domésticos: Revisão de literatura. Revista Científica Eletrônica de Medicina Veterinária, v. 6, n. 11, p. 1-7, 2008.

SOUZA, M.H.L.; ELIAS, D.O. Fundamentos da circulação extra corpórea. Segunda edição. Centro editorial Alfa Rio. Rio de janeiro, 2006.

SPIEGEL, J.E. et al. Safety and benefits of frutooligosaccharides as food ingredients. Food Technology, Boston, v.48, p.85-89, 1994.

STOKOL, T. Essential thrombocythemia and reactive thrombocytosis. In: Schalm's veterinary hematology, ed. Weiss, DJ, Wardrop, KJ, $6^{\mathrm{a}}$ ed., Pp. 605 - 611. Wiley, Ames, IA, 2010.

SUTHERLAND, R.J.; WHITNEY, M.S. Acute phase proteins in bovine inflammatory diseases. Texas Vet, Austin, v.57, n.6, p.27-29, 1995.

SWANSON, J.C.; MORROW-TESCH, J. Cattle transport: Historical, research, and future perspectives. Journal of Animal Science, v. 79, (E. Suppl.), p. E102-E109, 2001.

TAYLOR, J.A. Leukocyte responses in ruminants. In: FELDMAN, B.F.; ZINKL, J.G.; JAIN, N.C. Schalm's Veterinary Hematology, 5 ed. Philadelphia: Wilkins, p.891-898, 2000.

TENNANT, B.C. Hepatic function. In: KANEKO, J.J.; HARVEY, J.W.; BRUSS, M.L. Clinical Biochemistry of Domestic Animals. 5th ed. London: Academic Press. p.327352, 1997.

THOMAS, J.S. Non-immun-mediated thrombocytopenia. In: Schalm's veterinary hematology, ed. Weiss, DJ, Wardrop, KJ, 6ª ed., Pp. 596 - 604. Wiley, Ames, IA, 2010.

THRALL, M.A. Hematologia e Bioquímica Clínica Veterinária. $1^{\text {a }}$ ed. Roca: São Paulo, p. 114-117, 2007. 
TORNQUIST, S.J., RIGAS, J. Interpretation of ruminant leukocyte responses. In: Schalm's veterinary hematology, ed. Weiss, DJ, Wardrop, KJ, 6ª ed., Pp. 307 - 313. Wiley, Ames, IA, 2010.

TSEIMAZIDES, S. P. Efeitos do transporte rodoviário sobre a incidência de hematomas e variações de $\mathbf{p H}$ em carcaças bovinas. 60f. Dissertação (Mestrado) Faculdade de Ciências Agrárias e Veterinárias, Universidade Estadual Paulista, Jaboticabal, 2006.

TZORTZIS, G.; JAY, A. J.; BAILLON, M. L. A.; GIBSON, G. R.; RASTALL, R. A. Synthesis of $\alpha$-galactooligosaccharides with $\alpha$-galactosidase from Lactobacillus reuteri of canine origin. Applied Microbiology and Biotechnology, New York, v. 63, n. 3, p. 286$292,2003$.

UETAKE, K.; ISHIWATA, T.; TANAKA, T.; SATO, S. Physiological responses of young cross-bred calves immediately after long- haul road transportation and after one week of habituation. Animal Science Journal. 80(6): 705-708, 2009.

UYENO, Y.; SHIGEMORI, S.; SHIMOSATO, T. Effect of probiotics/prebiotics on cattle health and productivity. Microbes Environomental. v. 30, p.126-132, 2015.

VALADARES, R.F.D. et al. Níveis de proteína em dietas de bovinos. Concentrações de amônia ruminal e ureia plasmática e excreções de ureia e creatinina. Revista Brasileira de Zootecnia, v. 26, n. 6, p. 1270-1278, 1997.

VAN DE WATER, Geert; VERJANS, F.; GEERS, Rony. The effect of short distance transport under commercial conditions on the physiology of slaughter calves; $\mathrm{pH}$ and colour profiles of veal. Livestock Production Science, v. 82, n. 2-3, p. 171-179, 2003.

VIANA, R. B.; JUNIOR, E. H. B.; AYRES, M. C. C.; BIOJONI, F. S. M.; SOUZA, M. C. C.; BIRGEL, E. H. Influência da gestação e do puerpério sobre o leucograma de caprinos da raça Saanen, criados no Estado de São Paulo. Brazilian Journal Veterinary Research Animal Science, São Paulo, v. 39, n. 4, p. 196-201, 2002.

VYAS, D, UWIZEYE, A, MOHAMMED, R, YANG, WZ, WALKER, ND \& BEAUᄀCHEMIN, KA. The effects of active dried and killed dried yeast on sub-acute ruminal acidosis, ruminal fermentation, and nutrient digestibility in beef heifers', Journal Animal Science, vol.92, pp.724-732, 2014.

WARRIS, P.D. \& BROWN, S.N. \& ADAMS, S.J.M. Relationship between subjective and objective assessment of stress at slaughter and meat quality. Meat Science, v. 38, p. 329340, 1994.

WEBB JL, LATIMER KS. Leukocytes. In: Duncan and Prasse's veterinary laboratory medicine: clinical pathology, ed. Latimer KS, 5th ed., pp. 45-82. Wiley, Chichester, UK, 2011

WEISS, D.J.; PERMAN, V.P. Assessment of the hematopoietic system in ruminants. Veterinary Clinics of North America: Food Animal Pratice, Philadelphia, v.8, n.2, p.411429, 1992.

WHITE, B.J.; BLASI, D.; VOGEL, L.C.; EPP, M. Associations of beef calf wellness and body weight gain with internal location in a truck during transportation. Journal of Animal Science, v. 87, p. 4143-4150, 2009.

WILLARD, M.D. Hypoalbuminemia. In: FELDMAN, B.F. et al. Schalm's veterinary hematology. 5.ed. Philadelphia: Wilkins. p.891-898, 2000. 
WITTWER, F., REYES, J.M., OPITZ, H. et al. Determinación de úrea en muestras de leche de rebaños bovinos para el diagnóstico de desbalance nutricional. Arch. Med. Vet. 25, 165-172. 1993.

WOOD, D, QUIROZ-ROCHA, GF. Hematologia normal de bovinos. In: Schalm's veterinary hematology, ed. Weiss, DJ, Wardrop, KJ, $6^{\mathrm{a}}$ ed., Pp. 829 - 835. Wiley, Ames, IA, 2010.

YUN, J.W. Fructooligosaccharides occurrence, preparation, and application. Enzyme and microbial technology, v. 19, n. 2, p. 107-117, 1996.

ZANELLA, A.M.; SOUZA, D.R.S.; GODOY, M.F. Influência do exercício físico no perfil lipídico e estresse oxidativo. Arq Ciênc Saúde, v. 14, n. 2, p. 107-12, 2007.

ZHANG N.; JU Z.; ZUO T. Time for food: The impact of diet on gut microbiota and human health. Nutrition.; 51-52 80-85, 2018. 


\section{CARACTERISTICAS DE DESEMPENHO, CARCAÇA E PARAMETROS SANGUINEOS DE BOVINOS NELORE SUBMETIDOS AO TRANSPORTE E SUPLEMENTADOS COM MONENSINA E/OU MONENSINA E PREBIÓTICO}

\subsection{INTRODUÇÃO}

Sabe-se que o manejo pré-embarque, o percurso da viagem e o manejo durante o desembarque no confinamento são identificados como um dos principais agentes estressores na vida dos bovinos, promovendo consequentemente, impacto negativo na saúde e no desempenho desses animais durante o período de engorda (SWANSON E MORROW-TESCH, 2001; CARROLL E FORSBERG, 2007). Segundo Warris (1995) o percurso de viagem e o tempo de transporte fazem com que os animais percam peso progressivamente. $\mathrm{O}$ mesmo autor relata como média perdas de $7 \%$ a $12 \%$ do peso corporal em períodos, que variam de 12 horas a 24 horas de transporte atribuída ao jejum desses animais e consequente esvaziamento do trato digestivo.

Melhorias no manejo nutricional durante o período de engorda em confinamento podem ser implementadas dentro da propriedade, visando reduzir perdas econômicas ao produtor (SMITH, 1998). Assim, estudos que visam assegurar a saúde animal e melhorar o desempenho de bovinos, por meio de aditivos zootécnicos principalmente nas primeiras semanas de engorda em confinamento, tornam-se de extrema importância para a pecuária de corte.

De acordo com a literatura científica, vários tipos de prebióticos estão disponíveis na indústria de produção animal, tendo em suas composições um único composto, ou vários compostos, em proporções distintas dos seguintes ingredientes: frutooligossacarídeos (FOS), galactooligossacarídeos (GOS), mananooligossacarídeos (MOS) e Beta-glucanos (GIBSON et al., 1995). Importante mencionar que cada prebiótico possui sua própria função e auxilia na melhoria da saúde e do desempenho de animais de produção, como por exemplo o MOS, que tem o potencial de influenciar a população microbiana no trato intestinal aumento a número de bactérias benéficas ao hospedeiro (SPRING et al. 2000). Relato de Ghosh et al. (2012) mostraram efeitos benéficos no desempenho, ingestão de MS de bezerros mestiços recém-nascidos quando alimentados com MOS em comparação aos animais do grupo controle que não recebia o prebiótico.

Escassos são os trabalhos científicos no Brasil envolvendo a quantificação e/ou a redução do efeito deletério do transporte, bem como do uso alternativo de aditivos zootécnicos, como o uso de prebióticos, na saúde e no desempenho de bovinos Nelore recém-desembarcados em confinamento. Dessa forma, pesquisas dessa natureza poderão contribuir na adoção de novos aditivos zootécnicos, no intuito de melhorar a saúde e o desempenho de bovinos durante o período de engorda. Assim, objetiva-se com este trabalho avaliar o efeito da suplementação de diferentes 
prebióticos sobre o desempenho, as características de carcaça e parâmetros sanguíneos de bovinos Nelore sob estresse pelo transporte.

\subsection{MATERIAL E MÉTODOS}

Todos os procedimentos usados para esse experimento envolvendo animais foram conduzidos de acordo com o Comitê de Ética no Uso de Animais (CEUA número 2144140119), da Faculdade de Zootecnia e Engenharia de Alimentos da Universidade de São Paulo, Campus Fernando Costa.

\subsubsection{Animais, delineamento experimental e transporte}

O ensaio experimental foi conduzido nas instalações da Faculdade de Zootecnia e Engenharia de Alimentos do Departamento de Zootecnia da Universidade de São Paulo, Campus Fernando Costa, localizado em Pirassununga, SP (Latitude: -21.996, Longitude: -47.4268 $21^{\circ} 59^{\prime}$ 46" Sul, 47² 25' 36" Oeste). Durante o período de três de junho de 2019 a 16 de setembro de 2019 foi registrado pluviosidade total de $107,2 \mathrm{~mm}$ de chuva e temperaturas média de $20,45^{\circ} \mathrm{C}$, sendo registradas temperaturas mínimas de $3,8^{\circ} \mathrm{C}$ e máxima de $38,4^{\circ} \mathrm{C}$.

Quarenta e oito bovinos machos não castrados da raça Nelore contendo peso inicial de 380 $\mathrm{kg} \pm 16,44 \mathrm{~kg}$ e oriundos da Universidade de São Paulo, FZEA/USP, Campus de Pirassununga, SP foram utilizados no estudo em delineamento em blocos inteiramente casualizado contendo 4 tratamentos, sendo: tratamento controle (TC; dieta sem adição de aditivo zootécnico); tratamento monensina sódica (TMON; 25ppm de monensina/dia); tratamento monensina sódica + prebiótico1 (TMON Pb1; 25ppm de monensina/dia + 25 gramas de prebióticos por animal por dia contendo: betaglucanas, 300 g/kg, mananoligossacarídeos, 120 g/kg e glucomananos, 420 g/kg; Tratamento Monensina sódica + prebiótico $2(\mathrm{TMON} \mathrm{Pb} 2 ; 25 \mathrm{ppm}$ de monensina/dia +25 gramas de prebióticos por animal por dia contendo: 1,3 e 1,6 $\beta$-glucanos fosforilados, $150 \mathrm{~g} / \mathrm{kg}$, mananoligossacarídeos, $60 \mathrm{~g} / \mathrm{kg}$, frutooligossacarídeos, $120 \mathrm{~g} / \mathrm{kg}$, galactooligossacarídeos, 72 $\mathrm{g} / \mathrm{kg}$, glucomananos, $210 \mathrm{~g} / \mathrm{kg}$.

Os animais selecionados para este estudo eram oriundos de um mesmo rebanho, sendo estes alimentados em pastagem de brachiária brizantha cv. Marandu e suplemento contendo minerais até o início do experimento. Para maior controle experimental, um dia antes do início do estudo (D-3) realizou-se a pesagem dos animais em jejum (restrição hídrica e alimentar de 16 
horas) no início da manhã. Em seguida, no dia D-1, realizaram-se as coletas de sangue de todos os animais experimentais.

Figura 1- Pesagem dos animais durante o dia D-3.
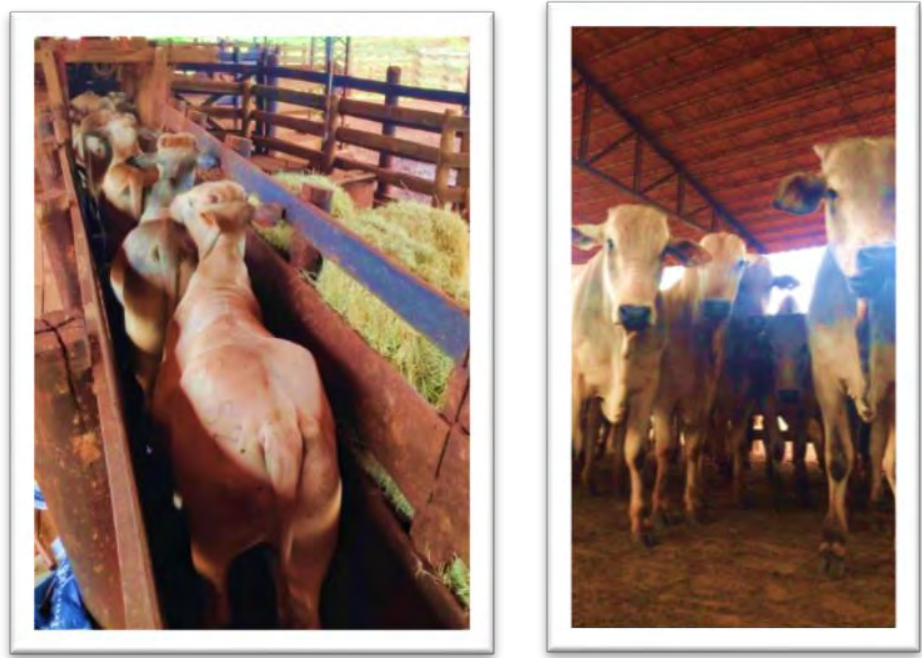

Fonte : Acervo Pessoal.

No dia D0, realizou-se a pesagem sem jejum e embarque dos quarenta e oito animais em três caminhões boiadeiros. Dezesseis animais (4 animais por tratamento) foram embarcados em cada caminhão, sendo estes transportados por aproximadamente 12 horas com o intuito de desencadear o estresse pela viagem. O percurso foi de aproximadamente $600 \mathrm{~km}$ em estradas do interior do estado de São Paulo. O embarque foi realizado no Departamento de Zootecnia da FZEA/USP às 07:00 horas, com o desembarque às 19 (D0) no mesmo local de partida. Os três caminhões saíram enfileirados se mantendo na mesma ordem durante todo o percurso de viagem. Com auxilio de data loggers fixados a altura próxima dos animais foram registrados a temperatura média do trajeto $20,01{ }^{\circ}$ Celsius, umidade relativa em $66,99 \%$ no primeiro e no ultimo caminhão.

Após o desembarque, estes animais foram acomodados em curral sem acesso a alimentação e a água até o dia D1, onde foi possível observar temperatura média durante a noite de $11,10^{\circ} \mathrm{C}$ e Umidade relativa próxima a $90 \%$. 
Figura 2- Animais após o desembarque no curral de espera.

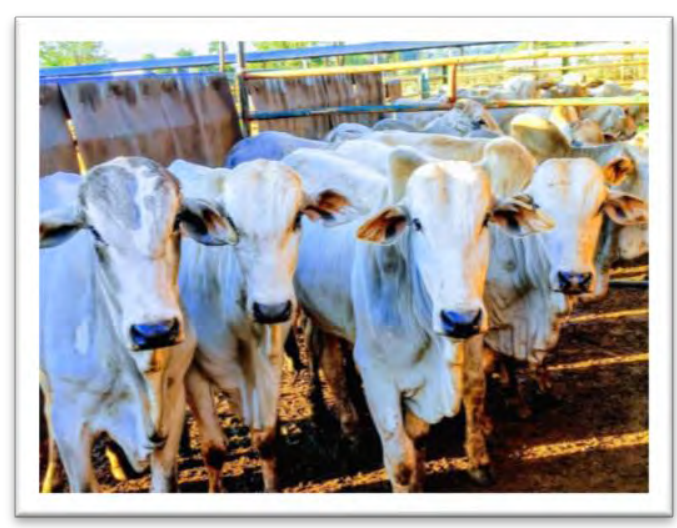

Fonte : Acervo Pessoal.

No dia D1 realizou-se nova pesagem a fim de estimar o peso vivo dos animais experimentais pós-viagem, bem como, amostras de sangue foram coletadas. Ainda no D1, realizou-se protocolo sanitário contendo uma dose de doramectina $1 \%$ (1 mL para cada $50 \mathrm{~kg}$ de peso vivo, Dectomax ${ }^{\circledR}$, Zoetis, Guarulhos, SP, Brasil ), vacina de clostridiose ( $3 \mathrm{~mL}$ por animal; Ourovac ${ }^{\circledR}$ Poli BT, Ourofino Saúde Animal Ltda, Cravinhos, SP, Brasil) e uma dose de albendazol 1,5\%, (1 mL para cada $50 \mathrm{~kg}$ de peso vivo, Agebendazol®, Agener União Saúde Animal, São Paulo, SP, Brasil ).

Figura 3- Primeiro dia de confinamento experimental.

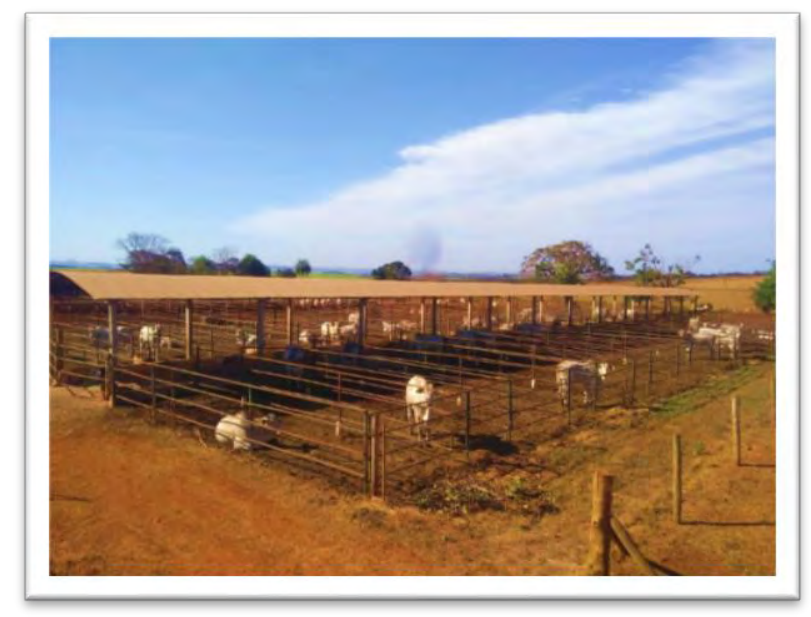

Fonte: Acervo Pessoal.

\subsubsection{Dieta e instalações}

Os animais foram alojados em baias individuais, contendo piso de concreto (3 metros de cocho linear para alimentação e bebedouros com enchimento automático). A ração experimental, 
na forma de mistura total (Tabela1), foi ofertada duas vezes ao dia (às 8:00 e às 14:00 horas, na proporção de $40 \%$ no período da manhã e $60 \%$ no período da tarde, em quantidade suficiente para permitir cerca de $5 \%$ de sobras no cocho. O consumo de matéria seca foi monitorado diariamente, com controle diário do oferecido e das sobras. Semanalmente, para o ajuste das proporções de cada ingrediente, avaliações semanais dos teores de matéria seca da silagem e do concentrado foram realizadas.

O período de confinamento teve duração médio de 100 dias (abate do primeiro lote com 97 dias e abate do segundo lote com 103 dias de engorda). A necessidade de realizar dois lotes de abate, foi devido a capacidade limitada de abate de animais nas instalações do Abatedouro da Faculdade de Zootecnia e Engenharia de Alimentos da Universidade de São Paulo, Campus Fernando Costa, Pirassununga, SP.

A dieta utilizada foi formulada com base na composição da matéria seca, visando atender as exigências de mantença e crescimento de bovinos Nelore conforme as exigências nutricionais propostas pelo CNCPS (Cornell Net Carbohydrate and Protein System, Fox et al., 1992) (Tabela 1). Vale ressaltar que as dietas que constituíam monensina o aditivo já era incluso no núcleo mineral, sendo o mesmo nível de garantia do produto para a dieta que não continha o aditivo.

O período de adaptação dos animais experimentais teve duração de 21 dias. Bovinos foram gradualmente adaptados a dieta de terminação utilizando 3 dietas intermediárias, sendo cada dieta oferecida por 7 dias (Tabela 1). Para evitar contaminação entre os aditivos avaliados neste estudo, optou-se por realizar a mistura da ração referente ao tratamento TC primeiramente, seguindo pelos tratamentos contendo monensina sódica (TOMN, TMON Pb1 e TMON Pb2). Os animais pertencentes aos tratamentos TMON Pb1 e TMON Pb2, receberam seus respectivos prebióticos na forma de "top dress" (25 g por animal por dia) junto com uma quantidade próxima de $1 \mathrm{~kg}$ de ração total, quantidade essa já incluída no cálculo de oferta diária, durante todo o período alimentar. Após a ingestão de toda a ração e aditivo, oferecia-se o restante da dieta do período da manhã. Tal prática visava garantir a ingestão diária de cada prebiótico.

Tabela 1- Composição da dieta experimental estimada segundo formulação (com base na MS)

\begin{tabular}{lcccc}
\hline & \multicolumn{4}{c}{ Dietas experimentais ${ }^{1}$} \\
\hline Ingredientes & Adaptação1 & Adaptação2 & Adaptação3 & Terminação \\
Silagem de milho & 55,00 & 45,00 & 35,00 & 27,00 \\
Milho moído & 31,90 & 44,43 & 57,26 & 65,58 \\
Farelo de soja & 10,17 & 7,53 & 4,27 & 3,98 \\
Uréia & 0,70 & 1,00 & 1,20 & 1,30 \\
Calcário & 1,17 & 0,97 & 1,07 & 0,94
\end{tabular}


Cloreto de potássio

Núcleo ${ }^{23}$

Composição química ${ }^{3}$

Matéria seca

Proteína bruta

NDT

Extrato etéreo

Fibra em detergente

Neutro da ração total

$\begin{array}{cccc}- & - & 0,12 & 0,12 \\ 1,07 & 1,07 & 1,07 & 1,07 \\ & & & \\ 46,02 & 50,41 & 55,74 & 62,45 \\ 14,50 & 14,50 & 14,00 & 14,00 \\ 74,25 & 76,25 & 78,00 & 80,0 \\ 3,00 & 3,23 & 3,46 & 3,55 \\ 31,00 & 27,72 & 24.38 & 23,59\end{array}$

Dieta ofertada do primeiro ao sétimo dia de confinamento; Dieta ofertada do oitavo ao décimo quarto dia de confinamento; Dieta ofertada do décimo quinto dia ao vigésimo primeiro dia de confinamento.

${ }^{2}$ Valores estimados segundo RLM 3.2 (Integra Software, Piracicaba, São Paulo, Brasil).

${ }^{2}$ Núcleo mineral (Tratamento com Monensina), níveis de garantia: Cálcio (Min) $220 \mathrm{~g} / \mathrm{kg}$, Cálcio (Max) 240g/kg, Fósforo (Min) 18g/kg, Magnésio (Min) 4g/kg, Enxofre (Min) 42g/kg, Sódio (Min) 105g/kg. Manganês (Min) $752 \mathrm{mg} / \mathrm{kg}$, Zinco (Min) $2.386 \mathrm{mg} / \mathrm{kg}$, Cobre (Min) $799 \mathrm{mg} / \mathrm{kg}$, Flúor (Max) 200mg/kg, Cobalto (Min) $11 \mathrm{mg} / \mathrm{kg}$, Iodo (Min) $57 \mathrm{mg} / \mathrm{kg}$, Cromo Orgânico (Min) 50mg/kg, Selênio (Min) $7 \mathrm{mg} / \mathrm{kg}$, Vitamina A (Min) $22.000 U \mathrm{UI} / \mathrm{kg}$, Vitamina E (Min) 4,8 mg/kg e Monensina Sódica (Min) 2.350mg/kg.

${ }^{3}$ Núcleo mineral (Tratamento sem Monensina), níveis de garantia: Cálcio (Min) $220 \mathrm{~g} / \mathrm{kg}$, Cálcio (Max) 240g/kg, Fósforo (Min) 18g/kg, Magnésio (Min) 4g/kg, Enxofre (Min) 42g/kg, Sódio (Min) 105g/kg. Manganês (Min) 752mg/kg, Zinco (Min) 2.386mg/kg, Cobre (Min) $799 \mathrm{mg} / \mathrm{kg}$, Flúor (Max) 200mg/kg, Cobalto (Min) $11 \mathrm{mg} / \mathrm{kg}$, Iodo (Min) $57 \mathrm{mg} / \mathrm{kg}$, Cromo Orgânico (Min) 50mg/kg, Selênio (Min) $7 \mathrm{mg} / \mathrm{kg}$, Vitamina A (Min) 22.000UI/kg, Vitamina E (Min) $4,8 \mathrm{mg} / \mathrm{kg}$.

Figura 4- Inclusão de prebiótico por meio do manejo "top dress".

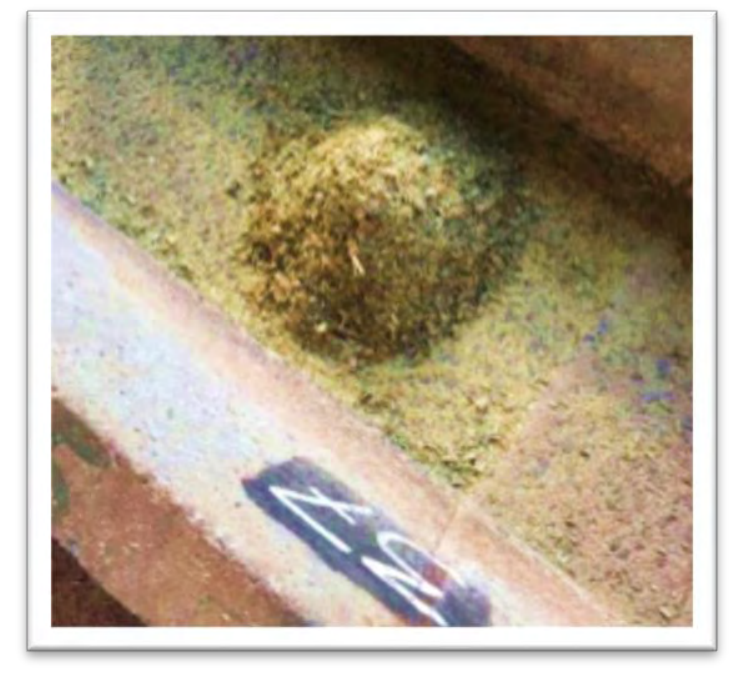

Fonte: Acervo Pessoal.

Amostras da dieta de terminação foram coletadas duas vezes na semana e alocadas em estufa de ar forçada a $105^{\circ} \mathrm{C}$ por 72 horas para ajustes da dieta alimentar com base na MS. Após 
essa mensuração, as amostras eram congeladas em freezer $-20^{\circ} \mathrm{C}$ até o final do experimento, secas em estufas de ar forçado a $55^{\circ} \mathrm{C}$ por 72 horas e moídas em moinho com tela de $1 \mathrm{~mm}$ (moinho Wiley, MA-680 arconi Ltda, Piracicaba, SP, Brasil). Ao final do estudo, uma amostra composta de cada ingrediente e da ração de cada tratamento foi selecionada para posterior análise laboratorial (Tabela2). As amostras foram realizadas em duplicata sendo: matéria seca (MS) a 105 -C (AOAC, 1990; método 930.15), proteína bruta (PB) pelo método de Dumas (Wiles et al., 1998), extrato etéreo (EE; AOAC, 1990; método 920,29), cinzas (AOAC, 1990; método 942,05), FDN (não sequencial e sem cinzas; Van Soest et al., 1991) e FDA como método 973,18 (Van Soest, 1973) e nutrientes digestíveis totais (NDT) pela equação proposta por Weiss et al. (1992). Para o ensaio de FDN utilizou-se fonte de amilase estável ao calor, conforme recomendado pela National Forage Testing Association (Undersander et al., 1993). Cada amostra recebeu $\alpha$-amilase (Sigma A3306; Sigma - Aldrich Brasil Ltda, São Paulo, SP, Brasil) e sulfito de sódio separadamente para a determinação de FDN. Ambos FDN e FDA foram expressos, excluindo as cinzas residuais.

Tabela 2- Composição química (com base na matéria seca) das dietas de terminação.

\begin{tabular}{lc}
\hline & Dieta de terminação \\
\hline Composição química & \\
Matéria seca & 54,9 \\
Proteína bruta & 15,26 \\
$\mathrm{MM}^{2}$ & 4,58 \\
$\mathrm{NDT}^{3}$ & 78,91 \\
$\mathrm{Extrato} \mathrm{etéreo}$ & 3,72 \\
$\mathrm{FDA}^{4}$ & 15,68 \\
Fibra em detergente neutro & 26,84 \\
\hline${ }^{1}$ Análises realizadas em laboratório de bromatologia \\
${ }^{2} \mathrm{MM}=$ matéria mineral \\
${ }^{2} \mathrm{NDT}=$ nutrientes digestíveis totais \\
${ }^{3} \mathrm{FDA}=$ fibra em detergente ácido
\end{tabular}

\subsubsection{Desempenho e colheita de amostras}

As pesagens dos animais, realizadas sem jejum, foram realizadas nos dias D1, D4, D7, D14, D21 e a cada 33 dias de alimentação. Contudo, ao final do período do confinamento realizouse pesagem em jejum (restrição hídrica e alimentar de 16 horas). Os dados de desempenho do período experimentas foram calculados com o peso pós desembarque dos animais. Esse método foi escolhido por se basear no manejo comumente utilizado em sistema de confinamento, onde 
animais que chegam aos confinamentos comerciais passam por muito tempo sem alimento e água e entram diretamente no sistema de engorda.

A avaliação do comportamento ingestivo dos animais, por vinte e quatro horas, por meio de observação visual foi realizada em duas etapas (nos dias 91 e 100 do período de alimentação). Dos 48 animais experimentais, 24 animais foram avaliados no dia 91 (etapa 1) e os 24 animais restantes foram avaliados no dia 100 do período experimental (etapa2). As atividades tiveram início imediatamente após o fornecimento da alimentação da manhã (07:00 horas). Os parâmetros avaliados em intervalos fixos de cinco minutos foram: ingestão de alimento, ingestão de água, ruminação ou ócio (MAEKAWA; BEAUCHEMIN; CHRISTENSEN, 2002). Os cálculos das atividades comportamentais foram efetuados em minutos por dia, assumindo que nos cinco minutos seguintes a cada observação o animal permaneceu na mesma atividade. $\mathrm{O}$ tempo total de mastigação foi determinado somando-se o tempo de ingestão de alimento e o tempo de ruminação (MAEKAWA; BEAUCHEMIN; CHRISTENSEN, 2002; KONONOFF, HEIRINCHS, LEHMAN, 2003). Usando os valores de ingestão (kg de MS) verificados no dia da realização do comportamento ingestivo, para cada animal, foram calculados os respectivos tempos relativos de ingestão, ruminação e mastigação em minutos por kg de MS. Refeições foram definidas como a somatória das atividades de consumo tomadas de cinco em cinco minutos para cada animal para cada tratamento. Para o cálculo da primeira refeição utilizou-se como início da contagem o momento que se ofereceu a ração total para cada animal e o término da contagem de tempo teve como critério a parada de consumo do animal por período de cinco minutos.

Amostras de sangue foram coletadas via veia jugular externa utilizando tubo "vacutainer" contendo 7,2 mg de K2 EDTA com anticoagulante para determinação do hemograma e tubo sem anticoagulante para a obtenção de soro para as análises bioquímicas nos dias D-1, D1, D4, D7, D14 e D21 e ao final do período do confinamento.

Amostras de sangue foram centrifugadas (Sorvall RC-3B Plus High Capacity Centrifuge) a uma velocidade de 3000 rotações por minuto, com temperatura constante de 4 graus Celsius durante 30 minutos. Ao final desse processo as amostras foram pipetadas em "eppendorfs" de $1,5 \mathrm{ml}$, e armazenadas em freezer $-80^{\circ}$ Celsius (Thermoscientific Ultrafreezer Series 900) onde foram congeladas para posterior análise.

Para as análises de bioquímica sérica foi utilizado o equipamento Mindray, BS120, China, para realização das seguintes análises: Uréia (método enzimático UV); Creatinina (método colorimétrico - Picrato alcalino - Jaffé); AST (Cinética UV-IFCC); GGT (Cinética - Szasz modificado); PT (Colorimétrica - Biureto); Albumina (Colorimétrica - Verde de Bromocresol), Globulinas (Cálculo matemático - PT=Albumina+Globulinas); CK (UV - IFCC). Todos os 
procedimentos laboratoriais foram realizados a uma temperatura de $37^{\circ} \mathrm{C}$. Valores de referência se encontram na Quadro 1.

Para as análises de hemograma utilizaram-se os equipamentos: Mindray BC- 2800 Vet, China e refratômetro portátil - Quimis; Microscópio Primo Star, Zeiss. Os kits comerciais foram: Zootest, Biobrasil: Z-Diluente, Z-Rinse, Z-Lyse, seguindo o método manual (contagem diferencial de leucócitos, morfologia celular), automática (leucócitos totais, hemácias, hemoglobina, hematócrito, índices hematimétricos absolutos, plaquetas), refratometria (proteína total plasmática) e precipitação pelo calor e refratometria (fibrinogênio). A coloração se baseou no método descrito por Rosenfeld (método May-Grunwald-Giemsa modificado). Todos os procedimentos laboratoriais foram realizados a uma temperatura de $37^{\circ} \mathrm{C}$. Valores de referência se encontram nos Quadros 2 e 3.

Quadro 1 - Valores médios em U/L para a atividade de enzimas hepáticas de bovinos segundo, Kaneko et al. (1997c) e Morais et al. (2000); Modificado de De Oliveira Paes (2005).

\begin{tabular}{|c|c|c|c|c|}
\hline Enzima & Pesquisadores & Condição 1 & Condição 2 & Valor médio \\
\hline \multirow{4}{*}{ CK } & Morais et al. (2000) & $\begin{array}{l}\text { Nelore } \\
\text { adulto }\end{array}$ & $\begin{array}{l}\text { Variável com a } \\
\text { época do ano }\end{array}$ & 45,5 a 165,3 \\
\hline & \multirow{3}{*}{$\begin{array}{l}\text { Kaneko et al. } \\
\text { (1997) }\end{array}$} & \multirow{3}{*}{ Bovinos } & Mínimo & 4,8 \\
\hline & & & Médio & 7,4 \\
\hline & & & Máximo & 12,1 \\
\hline Uréia & $\begin{array}{c}\text { Kaneko et al. } \\
\text { (1997) }\end{array}$ & Bovinos & - & 42,9 a 64,3 \\
\hline \multirow{5}{*}{ Creatinina } & $\begin{array}{c}\text { Kaneko et al. } \\
\text { (1997) }\end{array}$ & Bovinos & - & 1,0 a 2,0 \\
\hline & \multirow{4}{*}{ Morais et al. (2000) } & \multirow{4}{*}{$\begin{array}{l}\text { Nelore } \\
\text { adulto }\end{array}$} & Janeiro & 1,71 \\
\hline & & & Março & 1,76 \\
\hline & & & Agosto & 2,50 \\
\hline & & & Outubro & 2,28 \\
\hline \multirow{5}{*}{ AST } & $\begin{array}{c}\text { Kaneko et al. } \\
\text { (1997c) }\end{array}$ & Bovinos & - & $105(78-132)$ \\
\hline & \multirow{4}{*}{ Morais et al. (2000) } & \multirow{4}{*}{$\begin{array}{l}\text { Nelore } \\
\text { adulto }\end{array}$} & Janeiro & 88,79 \\
\hline & & & Março & 72,57 \\
\hline & & & Agosto & 49,88 \\
\hline & & & Outubro & 48,02 \\
\hline \multirow{5}{*}{$\begin{array}{l}\text { Fosfatase } \\
\text { alcalina }\end{array}$} & $\begin{array}{l}\text { Kaneko et al. } \\
\text { (1997c) }\end{array}$ & Bovinos & - & $\begin{array}{c}194 \\
(0-488)\end{array}$ \\
\hline & \multirow{4}{*}{ Morais et al. (2000) } & \multirow{4}{*}{$\begin{array}{l}\text { Nelore } \\
\text { adulto }\end{array}$} & Janeiro & 69,25 \\
\hline & & & Março & 69,20 \\
\hline & & & Agosto & 36,84 \\
\hline & & & Outubro & 39,33 \\
\hline
\end{tabular}




\begin{tabular}{|c|c|c|c|c|}
\hline GGT & $\begin{array}{c}\text { Kaneko et al. } \\
(1997 \mathrm{c})\end{array}$ & Bovinos & - & $15,7(6,1-17,4)$ \\
\hline
\end{tabular}

Quadro 2 - Valores normais do leucograma de bovinos segundo Jain (1993); Modificado de De Oliveira Paes (2005).

\begin{tabular}{|l|c|c|c|c|}
\hline \multicolumn{2}{|l|}{ Valores absolutos } & \multicolumn{2}{l|}{$\begin{array}{l}\text { Valores relativos } \\
(\%)\end{array}$} \\
\hline Tipo celular & Variação $(\mu \mathbf{L})$ & Média $(\mu \mathbf{L})$ & Variação & Média \\
\hline Leucócitos totais & $4.000-12.000$ & 8.000 & $x$ & $x$ \\
\hline Neutrófilos bastonetes & $0-120$ & 20 & $0-2$ & 0,5 \\
\hline Neutrófilos segmentados & $600-4.000$ & 2.000 & $15-45$ & 28,0 \\
\hline Linfócitos & $2.500-7.500$ & 4.500 & $45-75$ & 58,0 \\
\hline Monócitos & $25-840$ & 400 & $2-7$ & 4,0 \\
\hline Eosinófilos & $0-2.400$ & 700 & $0-20$ & 9,0 \\
\hline Basófilos & $0-200$ & 50 & $0-2$ & 0,5 \\
\hline
\end{tabular}

Quadro 3 - Valores médios de leucócitos em Bovinos da raça Nelore segundo Benesi et al. (2002) e Fagliari et al. (1998).

\begin{tabular}{|c|c|c|c|c|}
\hline Tipo celular & Pesquisadores & Condiçãa 1 & Condição 2 & $\begin{array}{l}\text { Valor médio } \\
(\text { céls } / \mu \mathbf{L})\end{array}$ \\
\hline \multirow{2}{*}{$\begin{array}{l}\text { Leucócitos } \\
\text { Totais }\end{array}$} & $\begin{array}{l}\text { Benesi et al. } \\
(2002)\end{array}$ & Nelore & Adultos & 13.572 \\
\hline & $\begin{array}{c}\text { Fagliari et al. } \\
\text { (1998) }\end{array}$ & Nelore & Adultos & 9.290 \\
\hline \multirow{2}{*}{ Neutrófilos } & $\begin{array}{l}\text { Benesi et al. } \\
\quad(2002)\end{array}$ & Nelore & Adultos & 2.954 \\
\hline & $\begin{array}{l}\text { Fagliari et al. } \\
\text { (1998) }\end{array}$ & Nelore & Adultos & 2.590 \\
\hline \multirow{2}{*}{ Linfócitos } & $\begin{array}{l}\text { Benesi et al. } \\
\quad(2002)\end{array}$ & Nelore & Adultos & 9.940 \\
\hline & $\begin{array}{l}\text { Fagliari et al. } \\
\text { (1998) }\end{array}$ & Nelore & Adultos & 5.890 \\
\hline Eosinófilos & $\begin{array}{l}\text { Benesi et al. } \\
\quad(2002)\end{array}$ & Nelore & Adultos & 621 \\
\hline Monócitos & $\begin{array}{l}\text { Benesi et al. } \\
\text { (2002) }\end{array}$ & Nelore & Adultos & 0 \\
\hline
\end{tabular}




\subsubsection{Abate}

Ao final do período de engorda os animais foram encaminhados ao Abatedouro da Faculdade de Zootecnia e Engenharia de Alimentos da Universidade de São Paulo. Antes do embarque, os animais foram pesados em jejum (restrição alimentar e hídrica de 16 horas) para posterior estimativas do rendimento de carcaça. Durante o abate, dados de peso de carcaça quente, gorduras renal, pélvica e inguinal, coração, fígado e rins foram coletados e pesados.

Figura 5- Abate dos animais experimentais.
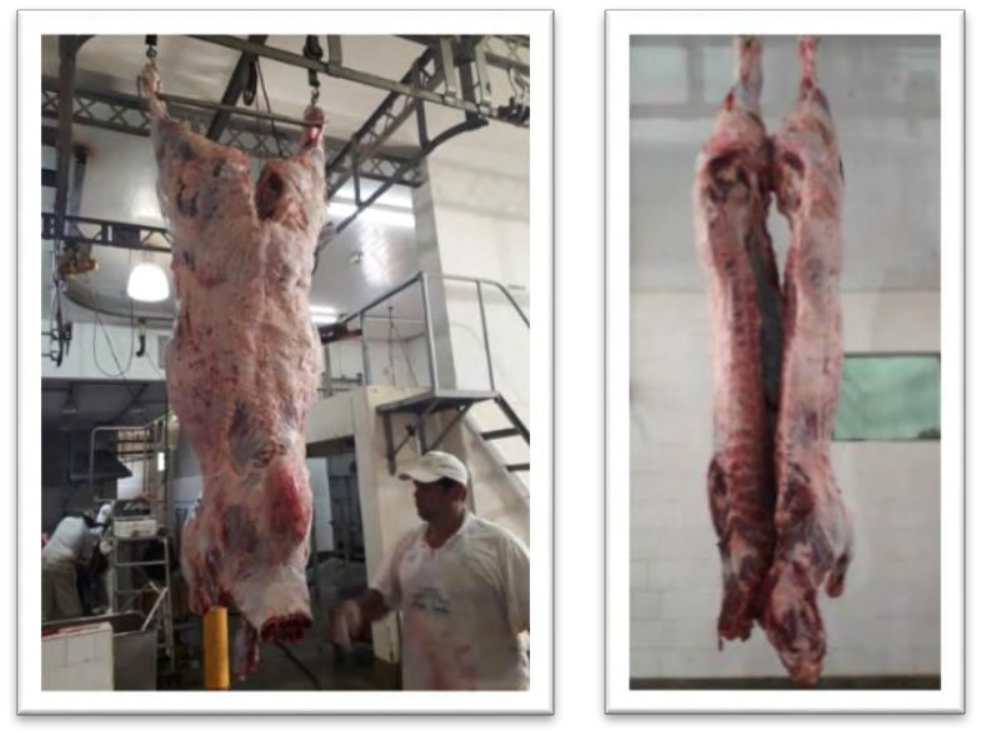

Fonte : Acervo Pessoal.

Após 24 horas de resfriamento, a meia-carcaça esquerda de cada animal foi seccionada transversalmente entre a $12^{\mathrm{a}}$ e a $13^{\mathrm{a}}$ costela, para avaliação do músculo Longissimus dorsi (LD). Uma câmera digital acoplada a um dispositivo usado para manter distância fixa de $10 \mathrm{~cm}$ entre o músculo e o equipamento foi utilizado para determinação da área de olho de lombo (AOL) e da espessura de gordura subcutânea (EGS). As imagens foram obtidas e interpretadas por técnico experiente utilizando o software Lince (M\&S Consultoria Agropecuária Ltda., Pirassununga, São Paulo, Brasil).

Figura 6- Pesagem da carcaça quente. 


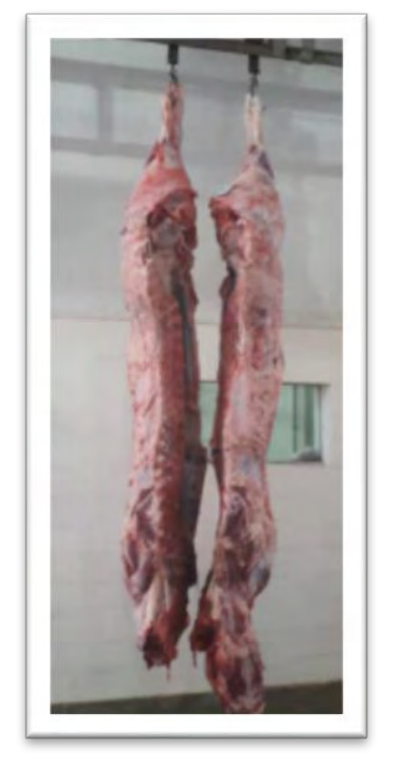

Fonte: Acervo Pessoal.

Figura 7- Método para cálculo da área de olho de lombo e espessura de gordura.

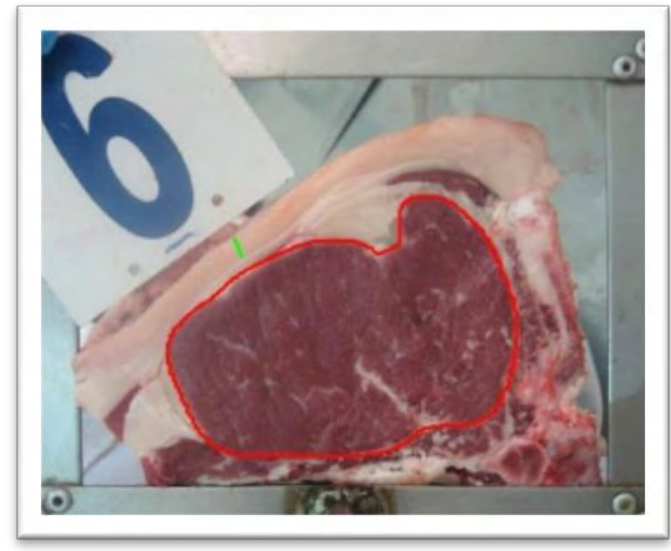

Fonte: Acervo Pessoal.

Figura 8- Croqui das coletas do confinamento.

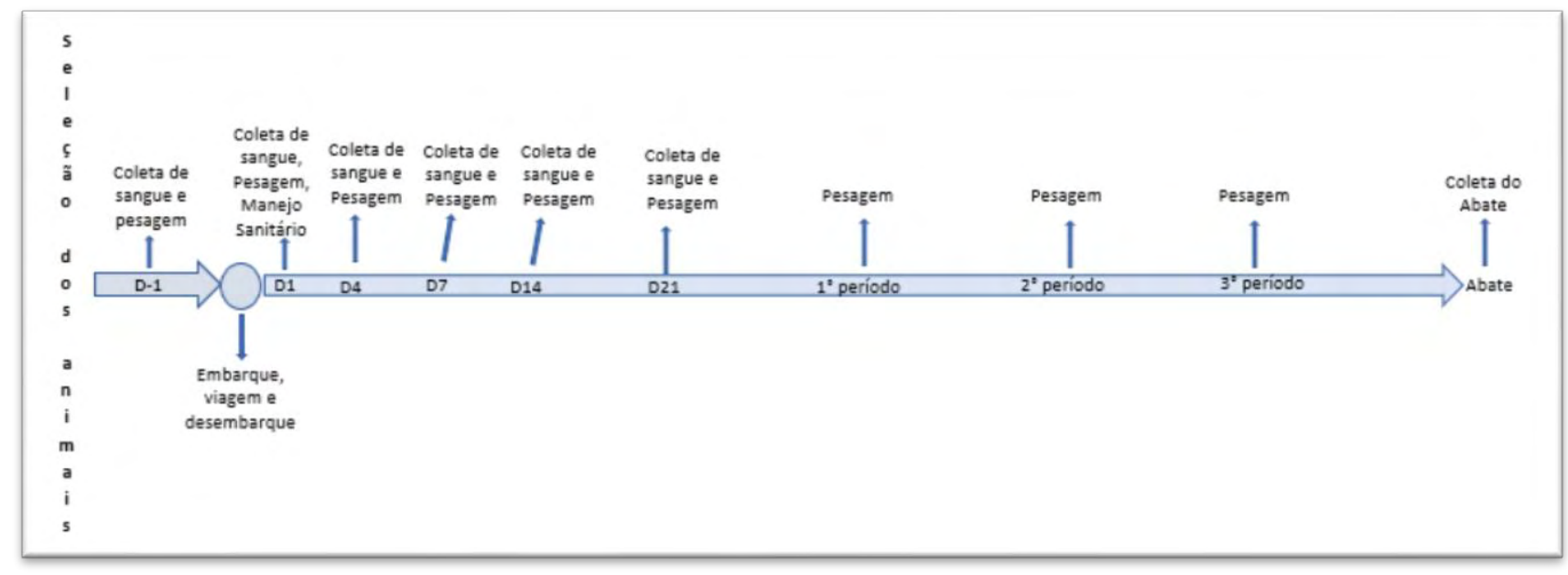




\subsubsection{Análise dos dados}

$\mathrm{O}$ experimento foi realizado em delineamento em blocos casualizados com quatro tratamentos (TC, TMON, TMON Pb1 e TMON Pb2) com 12 repetições por tratamento. O efeito dos tratamentos sobre as variáveis estudadas de desempenho, comportamento ingestivo e características de carcaça, foram avaliadas por análise de variância, considerando o tratamento como efeito fixo e como efeito aleatório os blocos (peso) e o dia de abate. Cada período de confinamento foi analisado separadamente dividido em: adaptação 1 (7dias), adaptação 2 (14 dias) adaptação 3 (21dias) e período total de confinamento. As análises foram conduzidas utilizando o procedimento MIXED do software SAS (SAS Institute Inc., Cary, NC). As características de hemograma e bioquímica do sangue, foram avaliadas como medidas repetidas no tempo. As matrizes de covariância foram testadas para cada característica e a de melhor ajuste foi utilizada (CROWDER \& HAND, 1990). As médias dos tratamentos foram obtidas pelo procedimento LSMeans e quando encontradas diferenças entre os tratamentos, foram comparados utilizando o Teste T de Student com nível de significância de 5\%.

\subsection{RESULTADOS E DISCUSSÃO}

Não houve diferença $(\mathrm{P}=0,996)$ entre os tratamentos no peso corporal pré-embarque e no peso corporal pós-desembarque, o que era esperado devido aos animais terem sido blocados por peso (Tabela 3). Consequentemente, resultados semelhantes $(\mathrm{P}=0.997)$ foram observados quanto a quebra de peso (kg e \% do peso corporal) entre os tratamentos TC, TMON, TMON Pb1 e TMON $\mathrm{Pb} 2$. Independente do aditivo utilizado neste estudo, bovinos submetidos em viagem por aproximadamente 12 horas somado a permanência no curral por mais 12 horas em jejum, apresentaram quebra de peso médio de $30,47 \mathrm{~kg}$ ou 7,41\% entre o peso corporal pré-embarque e o peso corporal pós-desembarque. 
Tabela 3 - Desempenho de bovinos Nelore sob estresse por transporte e alimentados sem aditivo, com monensina sódica ou monensina sódica e prébiotico em confinamento.

\begin{tabular}{|c|c|c|c|c|c|c|}
\hline Itens $^{3}$ & $\mathbf{T C}^{1}$ & TMON $^{1}$ & TMON Pb1 ${ }^{1}$ & TMON Pb2 ${ }^{1}$ & EPM $^{2}$ & $\begin{array}{c}\text { valor de } \\
\mathbf{P}\end{array}$ \\
\hline Peso Corp. Pré-emb., kg & 411 & 411 & 412 & 412 & 4,778 & 0,996 \\
\hline $\begin{array}{l}\text { Peso Corp. Pós-desen., } \\
\text { kg }\end{array}$ & 381 & 380 & 382 & 382 & 4,954 & 0,997 \\
\hline $\begin{array}{l}\text { Quebra de peso, kg de } \\
\text { PC } \\
\text { Quebra de peso, \% do }\end{array}$ & 30,48 & 30,56 & 30,76 & 30,10 & 1,232 & 0,984 \\
\hline $\begin{array}{l}\mathrm{PC} \\
\text { Primeiros sete dias de } \\
\text { confinamento }\end{array}$ & 7,42 & 7,44 & 7,47 & 7,31 & 0,311 & 0,984 \\
\hline $\begin{array}{l}\text { Peso corporal aos } 7 \text { dias, } \\
\mathrm{kg}\end{array}$ & 399 & 403 & 406 & 404 & 4,98 & 0,809 \\
\hline GPD, $\mathrm{kg}$ & 2,62 & 3,25 & 3,50 & 3,22 & 0,261 & 0,121 \\
\hline CMS, kg & 7,72 & 7,38 & 7,69 & 7,65 & 0,149 & 0,356 \\
\hline CMS, $\%$ peso corporal & 1,98 & 1,97 & 1,96 & 1,94 & 0,017 & 0.375 \\
\hline EA & 0,339 & 0,441 & 0,456 & 0,420 & 0,036 & 0,118 \\
\hline $\begin{array}{l}\text { Primeiros } 14 \text { dias de } \\
\text { confinamento }\end{array}$ & & & & & & \\
\hline $\begin{array}{l}\text { Peso corporal aos } 14 \text { dias, } \\
\mathrm{kg}\end{array}$ & 431 & 437 & 434 & 432 & 5,06 & 0,875 \\
\hline GPD, kg & 3,59 & 4,05 & 3,73 & 3,65 & 1,68 & 0,185 \\
\hline CMS, kg & 9,04 & 8,95 & 8,98 & 9,02 & 0,177 & 0,982 \\
\hline CMS, \% peso corporal & 2,22 & 2,26 & 2,20 & 2,22 & 0,029 & 0,529 \\
\hline EA & 0,397 & 0,455 & 0,416 & 0,405 & 0,017 & 0,105 \\
\hline $\begin{array}{l}\text { Primeiros } 21 \text { dias de } \\
\text { confinamento }\end{array}$ & & & & & & \\
\hline $\begin{array}{l}\text { Peso corporal aos } 21 \text { dias, } \\
\mathrm{kg}\end{array}$ & 441 & 449 & 445 & 446 & 6,077 & 0,870 \\
\hline GPD, kg & 2,88 & 3,26 & 3,03 & 3,06 & 0,147 & 0,351 \\
\hline CMS, kg & 10,02 & 9,97 & 9,77 & 9,87 & 0,236 & 0,881 \\
\hline CMS, \% peso corporal & 2,43 & 2,40 & 2,36 & 2,39 & 0,048 & 0,753 \\
\hline EA & 0,287 & 0,328 & 0,310 & 0,309 & 0,013 & 0,161 \\
\hline $\begin{array}{l}\text { Período total de } \\
\text { confinamento }\end{array}$ & & & & & & \\
\hline Peso corporal final, $\mathrm{kg}$ & 585 & 607 & 582 & 596 & 9,639 & 0,260 \\
\hline GPD, $\mathrm{kg}$ & 2,13 & 2,34 & 2,08 & 2,22 & 0,089 & 0,213 \\
\hline CMS, kg & 9,41 & 9,68 & 8,84 & 9,57 & 0,353 & 0,299 \\
\hline CMS, \% peso corporal & 1,94 & 1,95 & 1,84 & 1,95 & 0,063 & 0,359 \\
\hline EA & 0,226 & 0,243 & 0,235 & 0,231 & 0,007 & 0,277 \\
\hline
\end{tabular}

${ }^{1} \mathrm{TC}=$ tratamento controle, sem adição de aditivo zootécnico; TMON = tratamento monensina sódica (25ppm de monensina/dia); TMON Pb1 $=$ TMON +25 gramas de prebióticos por animal por dia contendo: betaglucanas, $300 \mathrm{~g} / \mathrm{kg}$, mananoligossacarídeos, $120 \mathrm{~g} / \mathrm{kg}$ e glucomananos, 420 $\mathrm{g} / \mathrm{kg}$; TMON Pb2 = TMON + 25 gramas de prebióticos por animal por dia contendo: 1,3 e 1,6 $\beta$ glucanos fosforilados, $150 \mathrm{~g} / \mathrm{kg}$, mananoligossacarídeos, $60 \mathrm{~g} / \mathrm{kg}$, frutooligossacarídeos, $120 \mathrm{~g} / \mathrm{kg}$, galactooligossacarídeos, $72 \mathrm{~g} / \mathrm{kg}$, glucomananos, $210 \mathrm{~g} / \mathrm{kg}$. 
${ }^{2}$ Erro padrão da média.

${ }^{3}$ Peso Corporal Pré-embarque, kg; Peso Corporal Pós-desenbarque, kg; GPD = ganho de peso médio diário, $\mathrm{kg} /$ dia; $\mathrm{CMS}=$ consumo de matéria seca, $\mathrm{kg} /$ dia e $\%$ do peso corporal; $\mathrm{EA}=$ eficiência alimentar

Letras distintas na mesma linha indicam diferença estatística pelo teste $\mathrm{T}$ ao nível de $5 \%$.

De acordo com Cole et al. (1988), o tipo de dieta ingerida e a condição corporal dos animais antes da viagem, bem como, a duração do transporte, afeta diretamente a perda de peso dos bovinos no momento do desembarque no confinamento. Barnes et al. (2004), relataram que a perda de peso de animais pós-transporte pode vaiar entre 6 a $10 \%$, sendo parte dessa perda de peso ocasionada pelo esvaziamento do conteúdo do trato gastrointestinal e parte por perdas relacionadas a substancias da própria carcaça como fluidos intra e extracelulares. Dados reportados por Knowles (1995), demonstrou perdas de peso corporal entre 7 a $8 \%$ em bovinos transportados por tempo superior a 24 horas. Além disso, Knowles (1995) afirmou que essas perdas são progressivas, mas em grande parte, se dá nas primeiras 15 horas de viagem.

No presente trabalho, o tempo de viagem foi de aproximadamente 12 horas, somado ao período de descanso no curral durante o período da noite, totalizando aproximadamente 24 horas de restrição hídrica e alimentar. Assim, o manejo adotado neste trabalho visou mimetizar o estresse sofrido por animais em situação de confinamentos comerciais. De modo geral, em confinamentos comerciais, é comum observamos animais sendo desembarcados após várias horas de viagem e em seguida permanecer em currais por períodos longos, sem acesso a água ou alimento, até a completa separação em lotes e realização de protocolo sanitário.

Resultados semelhantes foram obtidos por Earley et al. (2013), em que avaliaram dois grupos de animais, um que sofreu o efeito de transporte e outro que foi somente movido para baia concomitantemente aos transportados, ambos sob jejum. Tanto os animais que sofreram estresse de transporte quanto os que somente sofreram jejum não conseguiram retornar ao seu peso inicial nas primeiras 24 horas, mostrando que não somente o transporte como o jejum também é causa de perda de peso nos animais. Knowles et al. (1996), em trabalho posterior ao já mencionado, estudou a perda de peso em decorrência do efeito do transporte e o tempo em jejum e observou que animais que passaram por transporte de 24 horas sem acesso a alimentação, perderam entre 7 e $3 \%$ do peso inicial, enquanto os animais que passaram por 15 horas de transporte nas mesmas condições perderam em média $6,4 \%$ do peso quando comparado ao peso anterior a viagem.

Não houve efeito entre os diferentes aditivos testados neste trabalho quanto ao peso corporal ( $\mathrm{P}=0,809)$, o GPD ( $\mathrm{P}=0,121)$, o CMS (kg e \% do $\mathrm{PC} ; \mathrm{P}=0,356, \mathrm{P}=0,375$, respectivamente) e a EA $(\mathrm{P}=0,118)$ durante os primeiros sete dias de adaptação (Tabela 3$)$. Self 
e Gay (1972) relataram que bezerros que foram transportados por um percurso de $1089 \mathrm{~km}$ perderam em média de 7 a 9\% do peso corporal, sendo necessário um período superior a dez dias para que o peso corporal dos bovinos atingisse valores semelhantes ao período anterior a viagem. Os mesmos autores relataram que $46,7 \%$ é referente ao peso do conteúdo do TGI e foi recuperado quando fornecido ração e água aos animais, enquanto 53,3\% do peso corporal foi relacionado com perdas envolvendo constituintes da carcaça, principalmente água. Resultados semelhantes foram observados no presente trabalho, em que aos sete dias de confinamento, os animais recuperaram $71,9 \%$ do peso corporal quando comparado ao dia do embarque, demostrando que $28,1 \%$ das perdas podem estar relacionadas a carcaça e não a conteúdo ruminal e bexiga, sendo necessário um período superior a sete dias para a recuperação total do peso.

Não houve efeito entre os diferentes aditivos testados neste trabalho quanto ao peso corporal $(\mathrm{P}=0,875)$, o GPD ( $\mathrm{P}=0,185)$, o CMS $(\mathrm{kg}$ e \% do $\mathrm{PC} ; \mathrm{P}=0,982, \mathrm{P}=0,529$, respectivamente) e a EA $(\mathrm{P}=0,105)$ durante os primeiros 14 dias de adaptação (Tabela 3$)$. $\mathrm{O}$ não efeito do uso de monensina ou do uso monensina mais o prebióticos no desempenho animal, encontra-se contrário a alguns autores que relataram efeito positivo do uso de prebióticos. Ghosh e Mehla (2011) trabalhando com o fornecimento de prebióticos (MOS proveniente de parede celular de $S$. cerevisiae na dose de $4 \mathrm{~g} / \mathrm{animal} / \mathrm{dia}$ ) em bezerros recém-nascidos comparado a animais que não ingeriram o aditivo, observou melhora no ganho de peso desses animais. Resultados como esse são esperados segundo os mesmos autores, devido a capacidade potencial do MOS em se ligar a parede de bactérias patogênicas evitando com que as mesmas colonizem o trato intestinal dos animais (QUIGLEY et al., 2002). A maior dose de MOS ministrada aos animais do presente estudo foi de $3 \mathrm{~g} / \mathrm{animal} / \mathrm{dia}$, o que nos leva a pensar em uma sub dosagem do aditivo para a categoria animal escolhida e não efeito na colonização de bactérias benéficas no trato intestinal e por consequência ausência de efeito nos parâmetros de desempenho.

Zanine et al. (2006) fizeram um compilado de 228 experimentos utilizando monensina sódica em dietas de confinamentos e relataram que o uso do aditivo reduziu o consumo entre 8 a $10 \%$ em animais alimentados com alto teor de amido e melhorou a conversão alimentar, mantendo ou aumentando o ganho médio diário. No presente estudo, animais pertencentes aos tratamentos TMON, TMON Pb1 e TMON Pb2 apresentaram resultados semelhantes aos animais do tratamento TC, não demonstrando nenhum efeito positivo no uso de monensina sódica e/ou o uso combinado de monensina sódica e prebióticos.

Animais Nelore suplementados com dietas pertencentes aos tratamentos TMON, TMON $\mathrm{Pb} 1, \mathrm{TMON} \mathrm{Pb} 2$ e TC apresentaram resultados semelhantes quanto ao peso corporal aos 21 dias de confinamento ( $\mathrm{P} 0,870)$, GPD ( $\mathrm{P}=0,351)$, CMS (kg e \% do peso corporal; $\mathrm{P}=0,881, \mathrm{P}=$ 
0,753, respectivamente) e eficiência alimentar $(\mathrm{P}=0,161)$ (Tabela 3). Importante ressaltar que independente do aditivo avaliado, o impacto da viagem no desempenho dos animais aos 21 de confinamento foi semelhante ao TC. Ao avaliar os primeiros 21 dias de confinamento, observouse média de $3.05 \mathrm{~kg}$ de GPD entre os tratamentos, ressaltando o impacto na viagem neste período. Coffey et al. (2001), relataram como necessário para que o animal atinja seu peso anterior ao transporte, um período superior a 30 dias de confinamento. Contudo, no presente estudo, observou-se que foi necessário menos de 30 dias de confinamento para que os animais atingissem o peso anterior ao transporte (D-1).

Ao avaliar o período total de confinamento, não houve efeito entre os diferentes aditivos testados neste estudo quanto ao peso corporal $(\mathrm{P}=0,260)$, o GPD $(\mathrm{P}=0,213)$, o CMS $(\mathrm{kg}$ e \% do peso corporal; $\mathrm{P}=0,299, \mathrm{P}=0,359$, respectivamente) e a eficiência alimentar $(\mathrm{P}=0,277)$ (Tabela 3). Independente do tratamento avaliado, observou-se média de peso corporal final de $592,5 \mathrm{~kg}$. Gomes et al. (2011) trabalhando com o fornecimento de monensina (30 ppm), probióticos (S. cerevisisae na dose de 0,6 g/kg de MS ingerida) e associação dos aditivos, não encontraram diferença quando comparado ao tratamento controle (dieta basal sem adição de aditivo) no desempenho de bovinos da raça Nelore em sistema de confinamento.

Ribeiro et al. (2015) em trabalho com dieta sem adição de aditivo, monensina (150 mg/animal/dia), simbióticos (S. cerevisiae, L. acidophilus, E. faecium, B. subtilis celulase, hemicelulase, xilanase, mananoligossacarídeo, levedura inativa), na dose de 2 g/animal dia) e associação entre os aditivos, não observaram diferença no desempenho de novilhas mestiças independentemente do aditivo utilizado o que está de acordo com os resultados encontrados no presente estudo. Mathew et al. (1993), relataram que em situações quando os animais estão em boas condições de manejo (baixo nível de estresse) um efeito de equilíbrio entre as bactérias benéficas e nocivas do hospedeiro, pode ocorre, ocasionando uma minimização dos possíveis benefícios dos prebióticos. Por outro lado, mesmo não havendo melhora no desempenho de bovinos suplementados com prebióticos, Brum (2006) relatou melhoras na condição sanitária dos animais, demonstrando menor contagem de ovos de helmintos em animais que receberam o tratamento que continha prebiótico.

Goodrich et al. (1984), sumarizando uma série de trabalhos envolvendo monensina relataram aumentos de ganho de peso na ordem de 1,6\% para animais que foram alimentados com o ionóforo. Já Magliocca et al. (1994) relatam ganhos de 6,5\% a mais para animais tratados com monensina sódica (200 mg/animal/dia) em relação a niacina (1g/animal/dia) e a animais que consumiram somente dieta basal sem adição de nenhum aditivo, fato esse não encontrado no presente estudo. 
Tabela 4 - Características de carcaça de bovinos Nelore sob estresse por transporte e alimentados sem aditivo, com monensina sódica ou monensina sódica e prébiotico em confinamento.

\begin{tabular}{|c|c|c|c|c|c|c|}
\hline Itens $^{3}$ & $\mathbf{T C}^{1}$ & TMON1 1 & TMON Pb1 ${ }^{1}$ & TMON Pb2 ${ }^{1}$ & $\mathbf{E P M}^{2}$ & Valor de $P$ \\
\hline$\overline{\mathrm{PCQ}, \mathrm{kg}}$ & 339 & 352 & 344 & 344 & 6,712 & 0,635 \\
\hline RC, kg & 57,56 & 57,49 & 58,50 & 57,44 & 9,411 & 0,231 \\
\hline GRPI, kg & 15,72 & 16,78 & 14,71 & 17,33 & 0,809 & 0,121 \\
\hline Fígado, kg & 6,89 & 7,40 & 6,65 & 7,25 & 0,259 & 0,177 \\
\hline Rins, kg & 1,07 & 1,04 & 0,94 & 0,99 & 0,041 & 0,139 \\
\hline Coração, kg & 1,79 & 1,80 & 1,73 & 1,80 & 0,058 & 0,797 \\
\hline $\mathrm{AOL}, \mathrm{cm}^{2}$ & 77,10 & 79,06 & 83,78 & 78,70 & 2,460 & 0,265 \\
\hline EGS, mm & $5,26^{\mathrm{ab}}$ & $6,16^{\mathrm{a}}$ & $4,64^{\mathrm{b}}$ & $5,84^{\mathrm{a}}$ & 0,330 & 0,011 \\
\hline
\end{tabular}

${ }^{1} \mathrm{TC}=$ tratamento controle, sem adição de aditivo zootécnico; $\mathrm{TMON}=$ tratamento monensina sódica (25ppm de monensina/dia); TMON Pb1 = TMON + 25 gramas de prebióticos por animal por dia contendo: betaglucanas, $300 \mathrm{~g} / \mathrm{kg}$, Mananoligossacarídeos, $120 \mathrm{~g} / \mathrm{kg}$ e Glucomananos, 420 $\mathrm{g} / \mathrm{kg}$; TMON Pb2 $=\mathrm{TMON}+25$ gramas de prebióticos por animal por dia contendo: 1,3 e 1,6 $\beta$ glucanos fosforilados, $150 \mathrm{~g} / \mathrm{kg}$, mananoligossacarídeos, $60 \mathrm{~g} / \mathrm{kg}$, frutooligossacarídeos, $120 \mathrm{~g} / \mathrm{kg}$, galactooligossacarídeos, $72 \mathrm{~g} / \mathrm{kg}$, glucomananos, $210 \mathrm{~g} / \mathrm{kg}$.

${ }^{2}$ Erro padrão da média.

${ }^{3} \mathrm{PCQ}=$ peso de carcaça quente; $\mathrm{RC}=$ rendimento de carcaça; GRPI = Gordura renal, pélvica e inguinal; $\mathrm{AOL}=$ Área de olho de lombo; EGS = Espessura de gordura subcutânea.

Letras distintas na mesma linha indicam diferença estatística pelo teste T ao nível de 5\%.

Não houve diferença entre os tratamentos avaliados neste estudo com relação ao PCQ (P $=0,635)$, rendimento de carcaça $(P=0,231)$, GRPI $(P=0,121)$, Fígado $(P=0,177)$, Rins $(P=$ 0,139), Coração $(\mathrm{P}=0,797)$ e AOL $(\mathrm{P}=0,265)$.

Resultados semelhantes aos apresentados neste trabalho foram relatados por Goodrich et al. (1984) quanto ao uso de monensina sódica (na dose de $31,8 \mathrm{mg} / \mathrm{kg}$ MS) quando comparado com dietas sem a adição de aditivo. De acordo com Goodrich, et al. (1984), em revisão, mesmo relatado que o uso do ionóforo melhorou o ganho de peso, reduziu o consumo de ração e melhorou a eficiência alimentar, tais autores sugeriram que o uso de monensina afetou pouco as características de carcaça. Gomes et al. (2009), avaliaram os efeitos da monensina sódica (0,3 $\mathrm{g} / \mathrm{kg})$, de leveduras $(0,6 \mathrm{~g} / \mathrm{kg})$ e a associação entre monensina e levedura $(0,3 \mathrm{~g} / \mathrm{kg}$ de monensina + 0,6 g/kg S. cerevisiae) para bovinos Nelore em confinamento e não observaram diferença no peso de carcaça quente, no peso de gordura pélvica e renal, bem como, no tamanho da área de olho de lombo quando comparados a animais que não receberam o ionóforo.

Animais pertencentes ao tratamento TMON apresentaram maior EGS $(\mathrm{P}=0,011)$ quando comparado com os tratamentos TMON Pb1 e TMON Pb2. Dificilmente essa diferença de EGS se deu devido aos tratamentos, uma vez que não houve efeito para nenhuma característica de desempenho no presente estudo, sendo possível efeito de individuo em resposta ao bom manejo 
adotado no período experimental. Observa-se que independente do tratamento avaliado neste estudo, todos os animais apresentavam EGS acima de 3,00 mm. Segundo Müller (1987), esperase valores de EGS acima de $3 \mathrm{~mm}$ para que não ocorra grande perda de água da carcaça durante o processo de resfriamento e abaixo de $5 \mathrm{~mm}$ para que não seja necessário recortes de gordura na carcaça, uma vez que essa gordura é altamente onerosa para o produtor.

Kuss et al. (2009) trabalhando com vacas de descarte notaram diminuição de EGS em animais que ingeriram monensina (200 mg/animal/dia) em comparação aos animais que receberam dieta sem aditivo (dieta controle), sendo observada redução de 2,1 mm (6,6 para 4,5mm) para os animais pertencente ao tratamento controle. Além disso, Kuss et al. (2009) concluíram que o ionóforo reduziu o rendimento de carcaça em 2,4 pontos percentuais $(53,5 \%$ vs. $51,1 \%$ ). Ao contrário dos resultados apresentados por Kuss et al. (2009), animais pertencentes ao tratamento TMON apresentaram maior espessura de gordura subcutânea quando comparado com os demais tratamentos.

Tabela 5- Comportamento ingestivo de bovinos Nelore sob estresse por transporte e alimentados sem aditivo, com monensina sódica ou monensina sódica e prébiotico em confinamento.

\begin{tabular}{lcccccc}
\hline & & & TMON & TMON & & Valor \\
Itens & TC & TMON $^{1}$ & Pb1 $^{1}$ & Pb2 $^{\mathbf{1}}$ & EPM $^{2}$ & de P \\
\hline Ingestão, min/dia & 183,18 & 193,64 & 189,03 & 202,14 & 19,250 & 0,707 \\
Ruminação, min/dia & 258,23 & 259,15 & 209,17 & 258,33 & 32,440 & 0,141 \\
Mastigação, min/dia & 441,79 & 469,04 & 398,33 & 461,67 & 45,365 & 0,172 \\
Tempo primeira refeição, min & 32,79 & 29,88 & 34,58 & 33,33 & 7,495 & 0,890 \\
Número de refeições, dia & 7,97 & 8,45 & 8,67 & 9,33 & 1,003 & 0,514 \\
Duração de cada Refeição, min & 22,64 & 23,61 & 23,12 & 22,32 & 1,750 & 0,956 \\
\hline
\end{tabular}

${ }^{1} \mathrm{TC}=$ tratamento controle, sem adição de aditivo zootécnico; TMON = tratamento monensina sódica (25ppm de monensina/dia); $\mathrm{TMON} \mathrm{Pb1}=\mathrm{TMON}+25$ gramas de prebióticos por animal por dia contendo: betaglucanas, $300 \mathrm{~g} / \mathrm{kg}$, mananoligossacarídeos, $120 \mathrm{~g} / \mathrm{kg}$ e glucomananos, 420 $\mathrm{g} / \mathrm{kg}$; TMON Pb2 = TMON + 25 gramas de prebióticos por animal por dia contendo: 1,3 e 1,6 $\beta$ glucanos fosforilados, $150 \mathrm{~g} / \mathrm{kg}$, mananoligossacarídeos, $60 \mathrm{~g} / \mathrm{kg}$, frutooligossacarídeos, $120 \mathrm{~g} / \mathrm{kg}$, galactooligossacarídeos, $72 \mathrm{~g} / \mathrm{kg}$, glucomananos, $210 \mathrm{~g} / \mathrm{kg}$.

${ }^{2}$ Erro padrão da média.

Letras distintas na mesma linha indicam diferença estatística pelo teste $\mathrm{T}$ ao nível de $5 \%$.

Não houve efeito entre os diferentes aditivos avaliados quanto ao tempo de ingestão em min/dia $(P=0,707)$, o tempo de ruminação $(P=0,141)$, o tempo de mastigação $(P=0,172)$, o tempo da primeira refeição $(\mathrm{P}=0,890)$, o número de refeições $(\mathrm{P}=0,514)$ e a duração de cada refeição $(\mathrm{P}=0,956)$. 
De acordo com Goulart et al. (2020) animais Nelore recebendo dieta contendo 20,24\% de FDN na ração total (base na MS) sem inclusão de nenhum aditivo, apresentaram tempo de ruminação e mastigação de 230 e 427 minutos/dia, respectivamente. No presente estudo, a média entre os tratamentos para tempo de ruminação e mastigação foi de 246 e 443 minutos/dia para animais Nelore recebendo dieta contendo 23,59\% de FDN na ração total (base na MS), valores estes semelhantes aos encontrados por Goulart et al. (2020).

Mariani (2010) relatou que independente da raça utilizada, Brangus ou Nelore, ingerindo monensina sódica apresentaram aumento no número de refeições por dia $(17,03$ vs 15,88$)$ e menor duração de cada refeição (13,83 vs 15,31) quando comparado com animais sem aditivo, sendo estes resultados contrários aos encontrados no presente estudo. A ausência de efeito (Tabela 5) entre os tratamentos está de acordo com Silva (2014), onde comparou diferentes inclusões de monensina (30 e $40 \mathrm{mg} / \mathrm{kg}$ da MS, $25 \mathrm{mg} / \mathrm{kg}$ da MS mais $30 \mathrm{mg} / \mathrm{kg}$ de monensina sódica e óleo funcional na dose de $400 \mathrm{mg} / \mathrm{kg}$ da MS) e não relatou efeito de tratamento para ingestão na MS (min/dia), mastigação (min/dia), tempo da primeira refeição (min) e número de refeições (dia).

Tabela 6- Bioquímica do sangue de bovinos Nelore sob estresse por transporte e alimentados sem aditivos, com monensina sódica ou monensina sódica e prébiotico em confinamento.

\begin{tabular}{lcccccc}
\hline & \multicolumn{7}{c}{ Tratamento } \\
\hline Caract. $^{3}$ & TC $^{\mathbf{1}}$ & TMON $^{\mathbf{1}}$ & $\begin{array}{c}\text { TMON } \\
\text { Pb1 }^{1}\end{array}$ & $\begin{array}{c}\text { TMON }_{\text {Pb2 }^{1}} \\
\text { EPM }^{\mathbf{2}}\end{array}$ & $\begin{array}{c}\text { Valor } \\
\text { de P }^{\text {P }}\end{array}$ \\
\hline Creatinina_mg/dL & $1,49^{\mathrm{c}}$ & $1,54^{\mathrm{ab}}$ & $1,58^{\mathrm{a}}$ & $1,50^{\mathrm{bc}}$ & 0,03 & 0,007 \\
AST_U/L & 64,26 & 65,72 & 62,84 & 63,73 & 1,33 & 0,390 \\
GGT_U/L & 19,73 & 19,41 & 20,59 & 19,17 & 0,59 & 0,066 \\
PT_g/dL & 6,6 & 6,61 & 6,55 & 6,63 & 0,05 & 0,648 \\
ALB_g/dL & 3,09 & 3,08 & 3,07 & 3,06 & 0,02 & 0,764 \\
GLB_g/dL & 3,48 & 3,47 & 3,43 & 3,45 & 0,05 & 0,915 \\
CK_U/L & 144,46 & 139,42 & 127,27 & 144,74 & 9,66 & 0,421 \\
\hline
\end{tabular}

${ }^{1} \mathrm{TC}=$ tratamento controle, sem adição de aditivo zootécnico; $\mathrm{TMON}=$ tratamento monensina sódica (25ppm de monensina/dia); TMON Pb1 $=$ TMON +25 gramas de prebióticos por animal por dia contendo: betaglucanas, $300 \mathrm{~g} / \mathrm{kg}$, mananoligossacarídeos, $120 \mathrm{~g} / \mathrm{kg}$ e glucomananos, 420 $\mathrm{g} / \mathrm{kg}$; TMON Pb2 = TMON + 25 gramas de prebióticos por animal por dia contendo: 1,3 e 1,6 $\beta$ glucanos fosforilados, $150 \mathrm{~g} / \mathrm{kg}$, mananoligossacarídeos, $60 \mathrm{~g} / \mathrm{kg}$, frutooligossacarídeos, $120 \mathrm{~g} / \mathrm{kg}$, galactooligossacarídeos, $72 \mathrm{~g} / \mathrm{kg}$, glucomananos, $210 \mathrm{~g} / \mathrm{kg}$.

${ }^{2}$ Erro padrão da média.

3 Creatinina; AST = aspartato amino-transferase; GGT = Gama-glutamiltransferase; $\mathrm{PT}=$ proteínas totais; $\mathrm{ALB}=$ Albumina; $\mathrm{GLB}=$ Globulinas; $\mathrm{CK}=$ Creatina-quinase .

Letras distintas na mesma linha indicam diferença estatística pelo teste $\mathrm{T}$ ao nível de $5 \%$. 
Com exceção da concentração da ureia plasmática, não houve interação entre os tratamentos avaliados neste estudo e o tempo de coleta para os parâmetros envolvendo a bioquímica do sangue dos animais.

Não houve efeito entre os diferentes aditivos avaliados quanto a bioquímica do sangue dos animais no presente estudo quanto aos valores médios de AST $(\mathrm{P}=0,390)$, GGT $(\mathrm{P}=0,066)$, proteínas totais $(\mathrm{P}=0,648)$, albumina $(\mathrm{P}=0,764)$, globulinas $(\mathrm{P}=0,915)$ e $\mathrm{CK}(\mathrm{P}=0,421)$ no período de confinamento, sendo todos os valores encontrados dentro do intervalo de referência para a espécie bovina segundo Morais et al. (2000) e Kaneko et al. (1997). Possivelmente, essa ausência de efeitos nos parâmetros de bioquímica e hemograma (apresentados na Tabela 8) no sangue dos animais se deriva do bom manejo dos animais, que mesmo em condições desfavoráveis, não ocasionou quadros enfermos dos animais (BRUM et al. 2006).

Segundo Mathew et al. (1993) o grau de estresse dos animais pode ser relativo com relação a saúde dos animais, onde animais que não se encontrar em quadros de alto estresse, há um equilíbrio entre as populações de bactérias benéficas e nocivas no trato gastrintestinal sendo notado ausência de efeito no uso de prebióticos, fato esse observado no decorrer do estudo.

Somente a concentração de creatinina apresentou diferença $(P=0,007)$ em relação aos diferentes aditivos avaliados, variando entre 1,49 mg/dL e 1,58 mg/dL. Há uma difícil explicação com relação ao efeito dos tratamentos nos valores de creatinina uma vez que, os parâmetros de creatinina encontram-se dentro do intervalo de referência para bovinos $(1,0 \mathrm{mg} / \mathrm{dL}$ a $2,0 \mathrm{mg} / \mathrm{dL})$, conforme sugerido por Kaneko et al. (1997).

Estima-se que um dos pilares relacionados ao bem-estar animal é que os animais possam deitar, realizando períodos de descanso durante o dia (Matarazzo, 2004; Bórnez et al., 2009). Tadich et al. (2009) buscando estudar o efeito do transporte de 12 horas em caminhão e 26 horas em navio, demostraram que um período de descanso de 10 horas com acesso somente a água, faz com que os animais se recuperem.

Mesmo não havendo efeito $(P=0,066)$ entre os tratamentos observou-se níveis de GGT acima dos valores de referência disponíveis na literatura, que de acordo com Kaneko et al. (1997) varia entre 6,1 e $17,4 \mathrm{U} / \mathrm{L}$.

Tabela 7- Bioquímica do sangue de bovinos Nelore sob estresse por transporte e alimentados sem aditivo, com monensina sódica ou monensina sódica e prébiotico em confinamento.

\begin{tabular}{|c|c|c|c|c|c|c|c|c|c|}
\hline \multicolumn{10}{|c|}{ Tempo } \\
\hline Caract. $^{3}$ & D-1 ${ }^{1}$ & D1 $^{1}$ & D4 $^{1}$ & D7 ${ }^{1}$ & D14 $^{1}$ & D21 $^{1}$ & D93/100' & EPM $^{2}$ & Valor de $\mathbf{P}$ \\
\hline Creatinina_mg/dL & $1,62^{\mathrm{b}}$ & $1.74^{\mathrm{a}}$ & $1,45^{\mathrm{c}}$ & $1,46^{\mathrm{c}}$ & $1,38^{\mathrm{d}}$ & $1,38^{\mathrm{d}}$ & $1.67^{\mathrm{ab}}$ & 0,03 & $<0,001$ \\
\hline
\end{tabular}




\begin{tabular}{llllllllll} 
AST_U/L & $70,05^{\mathrm{b}}$ & $78,61^{\mathrm{a}}$ & $59,83^{\mathrm{c}}$ & $53,08^{\mathrm{e}}$ & $57,54^{\mathrm{cd}}$ & $58,38^{\mathrm{cd}}$ & $71,49^{\mathrm{b}}$ & 1,64 & $<0,001$ \\
GGT_U/L & $18,55^{\mathrm{bc}}$ & $19,4^{\mathrm{b}}$ & $18,02^{\mathrm{c}}$ & $19,09^{\mathrm{bc}}$ & $18,18^{\mathrm{c}}$ & $19,87^{\mathrm{b}}$ & $24,98^{\mathrm{a}}$ & 0,64 & $<0,001$ \\
Proteínas_Totais_g/dL & $6,88^{\mathrm{a}}$ & $7,04^{\mathrm{a}}$ & $6,59^{\mathrm{b}}$ & $6,57^{\mathrm{b}}$ & $6,16^{\mathrm{c}}$ & $6,34^{\mathrm{d}}$ & $6,62^{\mathrm{b}}$ & 0,06 & $<0,001$ \\
Albumina_g/dL & $3,12^{\mathrm{b}}$ & $3,25^{\mathrm{a}}$ & $3,06^{\mathrm{bc}}$ & $3,01^{\mathrm{c}}$ & $2,87^{\mathrm{d}}$ & $2,92^{\mathrm{d}}$ & $3,30^{\mathrm{a}}$ & 0,03 & $<0,001$ \\
Globulinas_g/dL & $3,74^{\mathrm{a}}$ & $3,66^{\mathrm{ab}}$ & $3,36^{\mathrm{c}}$ & $3,52^{\mathrm{bc}}$ & $3,26^{\mathrm{cd}}$ & $3,42^{\mathrm{c}}$ & $3,27^{\mathrm{dc}}$ & 0,06 & $<0,001$ \\
CK_U/L & $156^{\mathrm{b}}$ & $209^{\mathrm{a}}$ & $83^{\mathrm{d}}$ & $100^{\mathrm{c}}$ & $135^{\mathrm{b}}$ & $139^{\mathrm{b}}$ & $149^{\mathrm{b}}$ & 10 & $<0,001$ \\
\hline
\end{tabular}

${ }^{1} \mathrm{D}-1=$ dia anterior a viagem; D1 = Dia posterior a viagem; D4= dia quatro de confinamento; D7= dia sete de confinamento; D14= dia quatorze de confinamento; D21= dia vinte um de confinamento; DIA FINAL $=$ Dia anterior ao abate dos animais.

${ }^{2}$ Erro padrão da média.

${ }^{3}$ Creatinina; AST $=$ aspartato amino-transferase; GGT = Gama-glutamiltransferase; $\mathrm{PT}=$ proteínas totais; $\mathrm{ALB}=$ Albumina; GLB = Globulinas; $\mathrm{CK}=$ Creatina-quinase.

Letras distintas na mesma linha indicam diferença estatística pelo teste $\mathrm{T}$ ao nível de $5 \%$.

Não houve interação entre os tratamentos avaliados neste estudo e o tempo de coleta quanto aos parâmetros de bioquímica do sangue dos animais.

Houve efeito $(\mathrm{P}<0,0001)$ entre os diferentes tempos de coleta quanto a bioquímica do sangue dos animais para as concentrações de creatinina ( $\mathrm{P}<0,001)$, AST $(\mathrm{P}<0,001)$, GGT $(\mathrm{P}<$ $0,001)$, proteínas totais $(\mathrm{P}=<0,001)$, albumina $(\mathrm{P}=<0,001)$, globulinas $(\mathrm{P}<0,001)$ e $\mathrm{CK}(\mathrm{P}<$ 0,001). Contudo, torna-se importante ressaltar que todos os valores mencionados na Tabela 7 encontram-se dentro do intervalo de referência para a espécie bovina segundo Morais et al. (2000), Kaneko et al. (1997) e Jain (1993).

Comparado ao dia que antecedeu a viagem (D-1), observou-se aumento de $7 \%$ nos níveis de creatinina no dia posterior a viagem (D1), sendo este comportamento reflexo de que o tecido muscular dos animais possuía energia na forma de creatina fosfato e mesmo com todo o processo de embarque e desembarque dos animais os mesmos ainda possuíam reserva para manutenção do tecido muscular.

No presente estudo foi possível observar elevação da AST após o período de desembarque no confinamento ( $\mathrm{P}<0,0001), 70 \mathrm{U} / \mathrm{L}$ a 78U/L (D1 e D-1, respectivamente) junto a CK, $156 \mathrm{U} / \mathrm{L}$ a 209 U/L no mesmo período indicando possível fadiga muscular como efeito da viagem. Tornase importante ressaltar que os resultados se encontram dentro dos valores de referência descritos por Morais et al. (2000). A AST segundo Carlson (1993) citado por Kaneko (1989), é reconhecida como indicadora inespecífica de necrose tecidual quando há aumento junto a CK. De maneira geral, AST é uma enzima presente no fígado, musculo esquelético e cardíaco, em se tratando de diagnóstico clinico, ela serve para confirmação de degeneração muscular quando associada a enzima músculo específica (CK) e quando associada a enzima hepatoespecífica confirma lesão hepática. 
Foi observado diferença na concentração de GGT ao longo do tempo do confinamento (P $<0,0001)$, sendo esta elevada ao final do período (24,98 U/L) em aproximadamente 34,6\% quando comparada ao início de confinamento. Essa enzima é encontrada em altas concentração no fígado, rins, pâncreas e intestino, sendo relacionada a doenças do sistema hepatobiliar. A atividade tecidual da GGT é alta nos túbulos renais, no entanto, uma lesão tubular aguda resulta em elevação rápida da atividade da GGT mensurada a partir da coleta na urina e não na corrente sanguínea (MEYER \& HARVEY 2004). Vale ressaltar que nenhuma desconformidade foi observada quanto a concentração de GGT no presente estudo.

Os valores de proteínas totais avaliados durante o período alimentar em confinamento apresentaram diferença ao longo do tempo ( $\mathrm{P}<0,0001$; Tabela 7), sendo observados dados de mínimo e máximo de $6,16 \mathrm{~g} / \mathrm{dL}$ a $7,04 \mathrm{~g} / \mathrm{dL}$ respectivamente, sendo estes valores considerados dentro do intervalo de referência proposto por Silva et al. (2008a) e Barros Filho (1995). De acordo com Silva et al. (2008a) e Barros Filho (1995), os valores de proteínas totais variaram entre 5,96 $\pm 0,49 \mathrm{~g} / \mathrm{dL}$ e $6,76 \pm 0,41 \mathrm{~g} / \mathrm{dL}$, respectivamente, para animais Nelore em confinamento. Segundo Matheus et al. (2001), o aumento da concentração de proteínas plasmáticas se dá devido à resposta imune do organismo animal aos desafios infecciosos. A combinação entre globulinas e albuminas reflete a mensuração de proteínas totais, sendo que, no plasma, a diferença se dá na concentração de fibrinogênio presente na fibrina durante o processo de coagulação (MEYER \& HARVEY 2004). O mesmo autor relata que o aumento de proteínas no sangue causa quadros de hiperproteinemia, tendo como motivo a desidratação ou aumento da síntese de globulinas e quadros de hipoproteinemia, por quadros de hiper-hidratação ou diminuição da produção de albumina (MEYER \& HARVEY 2004).

Os valores de albumina diferiram $(\mathrm{P}<0,0001)$ durante o período de confinamento, sendo observada elevação de $4,1 \%$ e $5,7 \%$ no D1 $(3,25 \mathrm{~g} / \mathrm{dL})$ e ao final do período $(3,30 \mathrm{~g} / \mathrm{dL})$, respectivamente, quando comparado ao D-1 (3,12 g/dL). Entretanto, importante ressaltar que os valores de albumina encontrados neste estudo se encontram dentro do intervalo de referência proposto por Meyer \& Harvey (2004) (2,5g/dL a 4,5g/dL) e por Fagliari et al. (1998) $(2,97 \mathrm{~g} / \mathrm{dL}$ a $3,29 \mathrm{~g} / \mathrm{dL}$ ) para bovinos.

Segundo Matheus et al. (2001), a concentração de globulina em animais em condições tropicais é proporcionalmente maior que a concentração de albumina. A relação A:G é de importante observação em avaliações clinicas uma vez que a inversão dos valores nessa proporção ocorre devido ao aumento na concentração de imunoglobulinas, principalmente $\gamma$-globulinas. No presente estudo, a relação A:G apresentou valores mínimos no D-1 de 0,83 e máximo ao final do confinamento de 1,00. Silva et al. (2008a) encontraram valores de 1,07 $\pm 0,48$ na relação A:G para 
animais confinados e 0,95 $\pm 0,38$ animais terminados em sistema de pastejo, sendo esses valores considerados reflexos fisiológicos aos efeitos de transporte e jejum que os animais passaram até chegar ao abatedouro.

Os níveis de CK foram significativos ao longo do tempo $(\mathrm{P}<0,001)$ indicando possível fadiga muscular com ausência de lesão grave, uma vez que, somente no dia posterior a viagem (D1) o valore de CK se encontrou fora do intervalo de referência, conforme sugerido por Morais et al. (2000), em que demonstraram valores entre $45 \mathrm{U} / \mathrm{L}$ e $165 \mathrm{U} / \mathrm{L}$ para a categoria de animais adultos da raça Nelore. Por ter meia vida curta (4 horas), o persistente aumento nos índices séricos de CK indicou suspeita de fadiga muscular ativa e contínua dos músculos (MORAIS et al., 2000). Assim, o aumento da CK no D1 em relação ao D-1, apresentando valor pouco acima do intervalo de referência, somado a concentração da AST em níveis considerados normais para a categoria animal, pode ser explicado pelo fato desses animais passarem um período superior a 24 horas em posição em pé, sem acesso a água e alimento exigindo gasto excessivo do tecido muscular para se manterem nesta condição. O medo do novo, a não adaptação a dieta e as novas instalações podem ter levado esses animais a ficarem em estado de "luta ou fuga" nos primeiros dias de confinamento, conforme sugerido por Swanson e Morrow-Tesh (2001).

Figura 9- Interação da ureia: Tratamento/tempo.

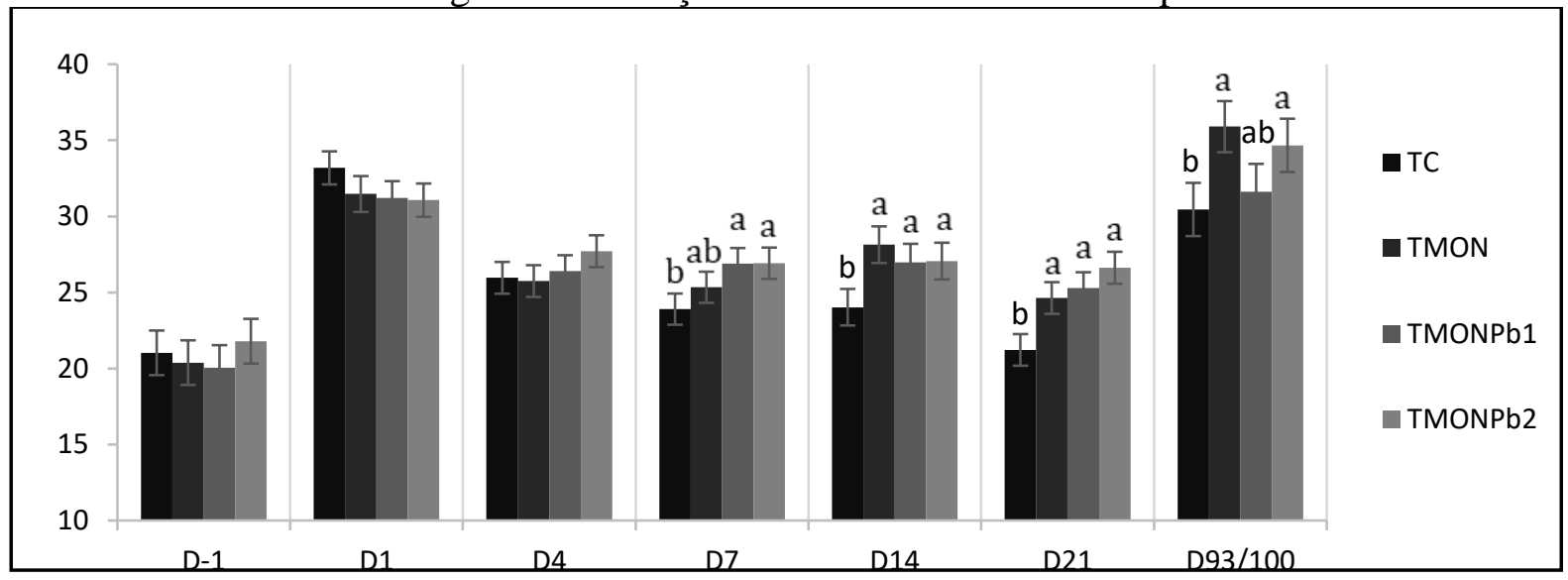

$\mathrm{TC}=$ tratamento controle, sem adição de aditivo zootécnico; $\mathrm{TMON}=$ tratamento monensina sódica (25ppm de monensina/dia); TMON Pb1 $=\mathrm{TMON}+25$ gramas de prebióticos por animal por dia contendo: betaglucanas, $300 \mathrm{~g} / \mathrm{kg}$, mananoligossacarídeos, $120 \mathrm{~g} / \mathrm{kg}$ e glucomananos, 420 $\mathrm{g} / \mathrm{kg}$; TMON Pb2 = TMON + 25 gramas de prebióticos por animal por dia contendo: 1,3 e 1,6 $\beta$ glucanos fosforilados, $150 \mathrm{~g} / \mathrm{kg}$, mananoligossacarídeos, $60 \mathrm{~g} / \mathrm{kg}$, frutooligossacarídeos, $120 \mathrm{~g} / \mathrm{kg}$, galactooligossacarídeos, $72 \mathrm{~g} / \mathrm{kg}$, glucomananos, $210 \mathrm{~g} / \mathrm{kg}$.

$\mathrm{D}-1=$ dia anterior a viagem; D1 = Dia posterior a viagem; $\mathrm{D} 4=$ dia quatro de confinamento; $\mathrm{D} 7=$ dia sete de confinamento; D14= dia quatorze de confinamento; D21= dia vinte um de confinamento; DIA FINAL= Dia anterior ao abate dos animais. 
Houve efeito da interação $(\mathrm{P}=0,049)$ entre os diferentes tratamentos e os tempos de coleta durante o período experimental quanto a concentração plasmática de ureia dos animais (Figura 9). Todos os valores encontrados estão dentro do intervalo de referência (17 mg/dL e $45 \mathrm{mg} / \mathrm{dL}$ ), oscilando dentro da amplitude de variação, não caracterizando insuficiência renal segundo Kaneko et al. (1997). Sauberlich (1999) relatou como ferramenta para se descobrir a quantidade de proteína no sangue em bovinos de corte inúmeras formas como: concentração de proteínas totais, albumina, relação de aminoácidos essenciais e não essenciais, relação entre albumina e globulinas, ureia e relação ureia e creatinina.

Houve o efeito $(\mathrm{P}<0,001)$ com relação a concentração plasmática de ureia ao longo do tempo de confinamento. Foi observado maiores valores de ureia plasmática no D1 e D93/100. A diferença (P < 0,001) observada do D-1 (20,81 mg/dL) em relação ao D1 (31,15 mg/dL) está em concordância com o relatado por Kassab e Mohammed (2014) que trabalhando com ruminantes sobre efeito de transporte (3 horas) observaram elevação dos níveis de ureia plasmática nos animais que passaram por transporte $(36,62 \mathrm{mg} / \mathrm{dL})$ quando comparado aos animais que não sofreram o manejo de viagem $(25,38 \mathrm{mg} / \mathrm{dL})$. Possivelmente a elevação da concentração dos níveis de ureia no sangue dos animais no D1 é justificada por Odore et al. (2004) que, alocaram 24 bezerros em caminhões e os transportaram por rodovias durante 14 horas. Os mesmos autores atribuíram a elevação da concentração de ureia no sangue desses animais logo após o desembarque a privação de alimento, que tem por consequência a degradação de proteína em virtude da hipoglicemia.

Maiores concentrações médias de ureia $(\mathrm{P}=0,153)$ no sangue dos animais foram observadas no D93/100 e D1 (33,15 mg/ dL e 31,73 mg/dL, respectivamente), sendo superiores em relação aos dias D4, D7 e D14 em 22,6\%, 25,9\% e 22,1\%, respectivamente. A maior diferença percentual $(55,8 \%)$ das concentrações de ureia no sangue dos animais foi observada entre os dias D93/D100 em relação ao D-1 de confinamento.

Houve efeito dos tratamentos a partir do D7 $(\mathrm{P}=0,0034)$ com relação aos níveis de ureia no sangue dos animais sendo os valores observados dentro do intervalo de referência proposto por Kaneko et al. (1997). Dados da literatura reportaram que a maior concentração plasmática de nitrogênio uréico no sangue está associada a mudanças na população microbiana de bovinos suplementados com monensina sódica (DUFFIELD et al. (2008); SCHELLING (1984)). Gandra et al. (2009), trabalhando com vacas holandesas de produção média de $25 \mathrm{~kg} /$ leite/dia e estudando o efeito da monensina em diferentes inclusões (ausência de monensina; $24 \mathrm{mg} / \mathrm{kg}$ de monensina; $48 \mathrm{mg} / \mathrm{kg}$ de monensina) observaram aumento da concentração de ureia no sangue dos animais que eram alimentados com o ionóforo, o que vai de acordo com o presente estudo, em que os 
maiores níveis de ureia dos animais que ingeriram mantiveram os níveis de ureia no sangue em concentrações elevadas comparado aos animais TC. O mesmo autor relata que a monensina possui efeito inibitório das bactérias ruminais ocasionando deaminação das proteínas, diminuindo a concentração de N-NH3 ruminal e consequentemente aumentando o fluxo de aminoácidos para o intestino delgado, ou seja, eleva a quantidade de proteína não degradável no rúmen (PNDR), elevando consequentemente as concentrações de N-ureico circulantes (GANDRA et al., 2009).

Tabela 8- Hemograma de bovinos Nelore sob estresse por transporte e alimentados sem aditivo, com monensina sódica ou monensina sódica e prébiotico em confinamento.

\begin{tabular}{|c|c|c|c|c|c|c|}
\hline \multicolumn{7}{|c|}{ Tratamento } \\
\hline Caract. & $\mathbf{T C}^{1}$ & TMON $^{1}$ & $\begin{array}{l}\text { TMON } \\
\text { Pb1 }^{1}\end{array}$ & $\begin{array}{l}\text { TMON } \\
\text { Pb2 }^{1}\end{array}$ & $\mathbf{E P M}^{2}$ & $\begin{array}{l}\text { Valor } \\
\text { de } P\end{array}$ \\
\hline Hemácias $\left(\times 10^{6} / \mu \mathrm{L}\right)$ & 8,58 & 8,49 & 8,78 & 8,84 & 0,16 & 0,130 \\
\hline Hemoglobina (g/dL) & 12,78 & 12,56 & 12,85 & 12,94 & 0,20 & 0,237 \\
\hline Hematócrito (\%) & 36,08 & 35,19 & 36,01 & 36,37 & 0,59 & 0,284 \\
\hline $\operatorname{VCM}(\mathbf{f L})^{3}$ & 42,37 & 41,56 & 41,41 & 41,39 & 0,51 & 0,232 \\
\hline HCM $(p g)^{4}$ & 14,96 & 14,76 & 14,72 & 14,68 & 0,16 & 0,408 \\
\hline CHCH $(\%)^{5}$ & 35,51 & 35,68 & 35,79 & 35,58 & 0,19 & 0,738 \\
\hline Leucócitos Totais $(/ \mu \mathrm{L})$ & $10.163^{\mathrm{a}}$ & $9.630^{\mathrm{bc}}$ & $9.799^{\mathrm{ab}}$ & $9.228^{c}$ & 312 & 0,009 \\
\hline $\begin{array}{l}\text { Neutrófilos segmentados } \\
(/ \mu \mathrm{L})\end{array}$ & 3649 & 3468 & 3492 & 3486 & 196 & 0,786 \\
\hline Linfócitos $(/ \mu \mathrm{L})$ & $5436^{\mathrm{a}}$ & $5208^{a}$ & $5454^{\mathrm{a}}$ & $4791^{b}$ & 164 & 0,003 \\
\hline Monócitos $(/ \boldsymbol{\mu L})$ & $385^{\mathrm{a}}$ & $377^{\mathrm{a}}$ & $296^{\mathrm{b}}$ & $297^{b}$ & 26 & 0,006 \\
\hline Eosinófilos $(/ \mu \mathrm{L})$ & 656 & 554 & 502 & 620 & 47 & 0,097 \\
\hline Basófilos $(/ \mu \mathrm{L})$ & 43 & 43 & 31 & 33 & 7 & 0,529 \\
\hline Plaquetas $(/ \mu \mathbf{L})$ & $410.061^{\mathrm{a}}$ & $329.094^{\mathrm{b}}$ & $350.327^{b}$ & $396.936^{\mathrm{a}}$ & 14.844 & $<, 0001$ \\
\hline Proteína plasmática (g/dL) & 7,39 & 7,39 & 7,40 & 7,43 & 0,05 & 0,901 \\
\hline Fibrinogênio (mg/dL) & 638 & 596 & 621 & 595 & 19 & 0,256 \\
\hline
\end{tabular}


${ }^{1} \mathrm{TC}=$ tratamento controle, sem adição de aditivo zootécnico; $\mathrm{TMON}=$ tratamento monensina sódica (25ppm de monensina/dia); TMON Pb1 $=$ TMON +25 gramas de prebióticos por animal por dia contendo: betaglucanas, $300 \mathrm{~g} / \mathrm{kg}$, mananoligossacarídeos, $120 \mathrm{~g} / \mathrm{kg}$ e glucomananos, 420 $\mathrm{g} / \mathrm{kg}$; TMON Pb2 $=\mathrm{TMON}+25$ gramas de prebióticos por animal por dia contendo: 1,3 e 1,6 $\beta$ glucanos fosforilados, $150 \mathrm{~g} / \mathrm{kg}$, mananoligossacarídeos, $60 \mathrm{~g} / \mathrm{kg}$, frutooligossacarídeos, $120 \mathrm{~g} / \mathrm{kg}$, galactooligossacarídeos, $72 \mathrm{~g} / \mathrm{kg}$, glucomananos, $210 \mathrm{~g} / \mathrm{kg}$.

${ }^{2}$ Erro padrão da média.

${ }^{3} \mathrm{VCM}=$ Volume corpuscular médio.

${ }^{4} \mathrm{HCM}=$ Hemoglobina corpuscular média.

${ }^{5} \mathrm{CHCH}=$ Concentração da hemoglobina corpuscular média.

Letras distintas na mesma linha indicam diferença estatística pelo teste $\mathrm{T}$ ao nível de $5 \%$.

Não houve interação $(P=0,886)$ entre os tratamentos avaliados neste estudo e o tempo de coleta para os parâmetros envolvendo o hemograma dos animais.

Não houve efeito dos tratamentos com relação ao hemograma dos animais do presente estudo com relação aos valores de hemácias $(\mathrm{P}=0,130)$ e hemoglobina $(\mathrm{P}=0,237)$. Para essas características os valores médios dos animais entre os tratamentos no presente estudo foram de $8,67 \times 10^{6} / \mu \mathrm{L}$ e $12,78 \mathrm{~g} / \mathrm{dL}$ respectivamente, valores estes considerados dentro do intervalo de referência para a bovinos Nelore saudáveis $(5,6$ x106/ $\mu \mathrm{L}$ a 13,90 x106/ $\mu \mathrm{L} ; 8,2 \mathrm{~g} / \mathrm{dL}$ a $15,8 \mathrm{~g} / \mathrm{dL})$ (Ayres et al., 2001).

Valores mínimos e máximos de 35,19\% e 36,37\% foram observados no hematócrito ( $\mathrm{P}=$ $0,284)$ dos animais no presente estudo, sendo estes valores considerados dentro do intervalo de referência (28\% a 45\%) para animais da mesma raça segundo AYRES et al. (2001).

Não houve efeito dos tratamentos quanto aos parâmetros hematológicos dos animais no presente estudo para VCM $(\mathrm{P}=0,232), \mathrm{HCM}(\mathrm{P}=0,408)$ e $\mathrm{CHCH}(\mathrm{P}=0,738)$ se encontrando dentro da faixa considerada normal para bovinos nelore segundo Ayres et al., (2001).

Houve efeito $(\mathrm{P}=0,009)$ na contagem de leucócitos totais no presente estudo entre os tratamentos, sendo estes valores considerados dentro do intervalo de referência $(4.000$ céls $/ \mu \mathrm{L}$ a 12.000 céls/ $\mu \mathrm{L}$ ) (Jain, 1993). Benesi et al. (2002) e Fagliari et al. (1998), relataram valores de leucócitos totais em bovinos da raça Nelore de 13.572 céls $/ \mu \mathrm{L}$ e 9.290 céls $/ \mu \mathrm{L}$ respectivamente. No presente estudo, o tratamento TC apresentou maior quantidade de leucócitos totais $(\mathrm{P}=0,009)$, impulsionado por valores elevados de monócitos e linfócitos. Menor quantidade de leucócitos totais foi observado no tratamento $\mathrm{TMONPb} 2$ devido ao menor número de linfócitos quando comparado aos demais tratamentos, bem como, monócitos quando comparado ao TC e TMON. Nenhuma diferença foi observada no presente estudo para basófilos $(\mathrm{P}=0,736)$ e eosinófilos $(\mathrm{P}=$ 0,148) sendo os valores encontrados dentro dos valores de referência $(0-200$ céls/ $\mu \mathrm{L} ; 0-2.400$ céls/ $\mu \mathrm{L}$ para basófilos e eosinófilo respectivamente) (Jain, 1993). 
Foi observado efeito ( $\mathrm{P}<0,0001)$ na contagem de plaquetas dos animais com relação aos tratamentos no presente estudo. Segundo Kramer (2000) os valores que compreende a contagem total de plaquetas no sangue variam entre 100.000 céls $/ \mu \mathrm{L}$ a 800.000 céls $/ \mu \mathrm{L}$ para bovinos. Fatores como excitação e medo, podem provocar uma alteração fisiológica nos parâmetros sanguíneos (JAIN, 1993). Devido à contração esplênica causada pela liberação de adrenalina/epinefrina frente a situações de estresse e/ou exercício, há aumento do estímulo da passagem das plaquetas do compartimento de armazenamento para o circulante, sendo possível observar aumento da concentração de plaquetas no sangue periférico (JONES \& ALLISON, 2007).

Não foi houve efeito $(\mathrm{P}=0,256)$ para fibrinogênio no presente estudo, sendo observados dentro dos valores de referência (300 a $700 \mathrm{mg} / \mathrm{dL}$ ) para bovinos descritos por Schalm e Jain (1986). Os valores médios para proteína total de bovinos confinados, estão acima dos achados por Doornenbal et al. (1988) para a mesma categoria animal (6,79 g/dL) e Barros Filho (1995), que encontrou 6,76 $\pm 0,41 \mathrm{~g} / \mathrm{dL}$, porém, próximos aos descritos por Kramer (2000) que considera como intervalo de reverencia para bovinos $7 \mathrm{~g} / \mathrm{dL}$ a $8,5 \mathrm{~g} / \mathrm{dL}$.

Tabela 9- Hemograma de bovinos Nelore sob estresse por transporte e alimentados sem aditivo, com monensina sódica ou monensina sódica e prébiotico em confinamento.

\begin{tabular}{|c|c|c|c|c|c|c|c|c|}
\hline \multicolumn{9}{|c|}{ Tempo } \\
\hline Caract. & D-1 ${ }^{1}$ & D1 ${ }^{1}$ & $\mathbf{D 4}^{1}$ & D7 ${ }^{1}$ & D14 ${ }^{1}$ & $\mathbf{D 2 1}^{1}$ & $\mathrm{EPM}^{2}$ & $\begin{array}{l}\text { Valor } \\
\text { de P }\end{array}$ \\
\hline Hemácias $(\mathbf{x 1 0} \% / \mu \mathrm{L})$ & $8,93^{\mathrm{b}}$ & $9,36^{\mathrm{a}}$ & $9,49^{a}$ & $8,78^{\mathrm{b}}$ & $7,79^{\mathrm{c}}$ & $7,70^{\mathrm{c}}$ & 0,17 & $<0,0001$ \\
\hline Hemoglobina (g/dL) & $13,39^{\mathrm{b}}$ & $13,92^{\mathrm{a}}$ & $13,85^{\mathrm{a}}$ & $12,64^{\mathrm{c}}$ & $11,29^{\mathrm{d}}$ & $11,60^{\mathrm{d}}$ & 0,22 & $<0,0001$ \\
\hline Hematócrito (\%) & $36,30^{\mathrm{b}}$ & $39,09^{\mathrm{a}}$ & $39,91^{\mathrm{a}}$ & $36,11^{\mathrm{b}}$ & $32,07^{\mathrm{c}}$ & $31,10^{\mathrm{c}}$ & 0,66 & $<0,0001$ \\
\hline $\operatorname{VCM}(\mathbf{f L})^{3}$ & 40,76 & 42,21 & 42,30 & 41,34 & 41,20 & 42,29 & 0,57 & 0,081 \\
\hline HCM $(p g)^{4}$ & $14,96^{\mathrm{ab}}$ & $14,96^{\mathrm{ab}}$ & $14,61^{\mathrm{bc}}$ & $14,42^{\mathrm{c}}$ & $14,52^{\mathrm{c}}$ & $15,23^{\mathrm{a}}$ & 0,18 & 0,0014 \\
\hline СНСН $(\%)^{5}$ & $36,88^{a}$ & $35,60^{c}$ & $34,73^{\mathrm{d}}$ & $35,04^{\mathrm{d}}$ & $35,39^{\mathrm{cd}}$ & $36,21^{\mathrm{b}}$ & 0,22 & $<0,0001$ \\
\hline Leucócitos Totais $(/ \mu \mathrm{L})$ & $11.642^{\mathrm{a}}$ & $10.973^{\mathrm{a}}$ & $9.662^{\mathrm{b}}$ & $8.273^{c}$ & $8.815^{\mathrm{c}}$ & $8.867^{\mathrm{c}}$ & 336 & $<0,0001$ \\
\hline Neutrófilos segmentados $(/ \mu \mathrm{L})$ & $3.900^{\mathrm{ab}}$ & $4.083^{\mathrm{a}}$ & $3.622^{b c}$ & $2.722^{\mathrm{d}}$ & $3.444^{\mathrm{c}}$ & $3.371^{\mathrm{c}}$ & 216 & $<, 0001$ \\
\hline Linfócitos $(/ \mu \mathrm{L})$ & $6.375^{\mathrm{a}}$ & $5.950^{\mathrm{a}}$ & $5.215^{\mathrm{b}}$ & $4.547^{\mathrm{c}}$ & $4.497^{\mathrm{c}}$ & $4.749^{c}$ & 187 & $<, 0001$ \\
\hline Monócitos $(/ \boldsymbol{\mu L})$ & $364^{\mathrm{abc}}$ & $418^{\mathrm{a}}$ & $280^{\mathrm{d}}$ & $298^{\mathrm{bcd}}$ & $292^{\mathrm{cd}}$ & $381^{\mathrm{ab}}$ & 30 & 0,001 \\
\hline Eosinófilos $(/ \mu \mathbf{L})$ & $970^{\mathrm{a}}$ & $497^{\mathrm{b}}$ & $520^{\mathrm{b}}$ & $651^{\mathrm{b}}$ & $524^{\mathrm{b}}$ & $336^{\mathrm{c}}$ & 56 & $<, 0001$ \\
\hline Basófilos $(/ \mu \mathrm{L})$ & 36,69 & 27,62 & 26,39 & 54,94 & 50,04 & 29,00 & 8,9 & 0,1044 \\
\hline Plaquetas $(/ \mu \mathbf{L})$ & 340.710 & 384.272 & 369.771 & 402.438 & 357.854 & 374583 & 17.542 & 0,1505 \\
\hline Proteína plasmática $(\mathrm{g} / \mathrm{dL})$ & $7,51^{\mathrm{b}}$ & $8,03^{\mathrm{a}}$ & $7,47^{\mathrm{b}}$ & $7,22^{\mathrm{c}}$ & $7,03^{\mathrm{d}}$ & $7,14^{\mathrm{cd}}$ & 0,06 & $<, 0001$ \\
\hline Fibrinogênio (mg/dL) & $479^{\mathrm{e}}$ & $604^{\mathrm{cd}}$ & $700^{\mathrm{a}}$ & $575^{\mathrm{d}}$ & $679^{\mathrm{ab}}$ & $637^{\mathrm{bc}}$ & 22 & $<, 0001$ \\
\hline
\end{tabular}

${ }^{1} \mathrm{D}-1=$ dia anterior a viagem; D1= Dia posterior a viagem; $\mathrm{D} 4=$ dia quatro de confinamento; $\mathrm{D} 7=$ dia sete de confinamento; D14= dia quatorze de confinamento; D21= dia vinte um de 
confinamento; DIA FINAL= Dia anterior ao abate dos animais.

${ }^{2}$ Erro padrão da média.

${ }^{3} \mathrm{VCM}=$ Volume corpuscular médio.

${ }^{4} \mathrm{HCM}=$ Hemoglobina corpuscular média.

${ }^{5} \mathrm{CHCH}=$ Concentração da hemoglobina corpuscular média.

Letras distintas na mesma linha indicam diferença estatística pelo teste $\mathrm{T}$ ao nível de $5 \%$.

Vale ressaltar que no período anterior ao início de experimento, bem como horas antes da primeira coleta de sangue os animais do estudo se encontravam em sistema de pastejo, não havendo contato frequente com humanos e currais de manejo. A adrenalina, hormônio resultante da excitação, causa esplenocontração com consequente liberação de uma massa de eritrócitos para a circulação sanguínea, induzindo a mobilização de leucócitos do compartimento vascular marginal para o compartimento circulante. Por esse motivo, era esperado elevação de leucócitos no presente estudo no D-1 resultado de um possível estresse denominada leucocitose fisiológica (SMITH, 2000). Lee et al. (1974) trabalhando com o efeito do estresse no quadro eritrocitário de bovinos, observaram alterações hematológicas desses animais minutos após ao estresse em resposta a adrenalina e cortisol e poucas horas devido ao efeito de corticosteroides.

Foram observados valores elevados de hemácias, hemoglobina e hematócrito no dia após de desembarque $(9,36 \times 106 / \mu \mathrm{L}, 13,92 \mathrm{~g} / \mathrm{dL}, 39,09 \%$, respectivamente $)$, dos quais permaneceram elevados até o dia D4 do confinamento $(9,49$ x106/ $\mu \mathrm{L}, 13,85 \mathrm{~g} / \mathrm{dL}$ e $39,91 \%)$ quando comparados ao dia anterior a viagem, D1 $(8,93 \times 106 / \mu \mathrm{L}, 13,39 \mathrm{~g} / \mathrm{dL}, 36,30 \%)$, porém, todos os valores encontram dentro da normalidade dos níveis de referência proposto por Ayres et al., (2001) (5,613,9 x10\% $/ \mu \mathrm{L}$ para hemácias, $8,2-15,8 \mathrm{~g} / \mathrm{dL}$ de hemoglobina e $28-45 \%$ do hematócrito). Valores aumentados desses parâmetros eram esperados no presente estudo, uma vez que, os animais passaram por jejum de 24 horas. Estudo feito por Earley et al. (2013), trabalhando com efeitos que o transporte (nove horas) causa em bovinos, observaram elevações dos valores de hemácias (8,06 x $10^{6} / \mu \mathrm{L}$ para $\left.9,74 \times 10^{6} / \mu \mathrm{L}\right)$, hemoglobina( $10,92 \mathrm{~g} / \mathrm{dL}$ para $\left.11,57 \mathrm{~g} / \mathrm{dL}\right)$ e hematócrito $(32,94 \%$ para 35,39\%) após o período de transporte e atribuíram esses aumentos ao jejum hídrico que esses animais passaram.

Houve efeito $(\mathrm{P}=0,0014)$ ao longo do tempo de confinamento no que diz respeito a HCM dos animais, sendo encontrado valores mínimos e máximos de 14,42pg no D7 e 15,23pg no D21, se encontrando dentro do intervalo de referência $(9,57 \mathrm{pg}-18,57 \mathrm{pg})$ para bovinos nelores segundo Ayres et al., (2001). Benatti (2013) que trabalhou com animais Nelore ao longo do confinamento encontraram valores de HCM de 13,90pg no início do projeto e 16,75pg ao final do período experimental e atribuiu esse comportamento a melhor alimentação dos animais que por 
consequência melhorou a adequada produção de células sanguíneas. Esse achado vai de acordo com este estudo e sugerindo que os animais não foram acometidos por enfermidades (anemias) e sim alterações causadas pela viagem respaldado pelo aumento nos níveis de ureia no sangue dos animais em dois períodos, no primeiro dia de confinamento (privação de agua e alimento) e ao final do período experimental (reflexo da dieta) .

Houve efeito $(\mathrm{P}<0,0001)$ com relação ao número de leucócitos totais ao longo do período de confinamento, não caracterizando quadro clinico de enfermidade pois tais parâmetros encontram dentro do intervalo de referência $(4000 / \mu \mathrm{L}$ a $12000 / \mu \mathrm{L})(\mathrm{Jain}, 1993)$. Em se tratando de animais enfermos, a liberação de substancias adrenocorticais relacionadas ao estresse, causa alterações consideradas medianas a elevadas no quadro leucocitário de bovinos (leucocitose fisiológica) (COLES, 1980).

Houve efeito $(\mathrm{P}<0,0001)$ com relação a concentração de fibrinogênio ao longo do tempo de confinamento oscilando entre 479 e $700 \mathrm{mg} / \mathrm{dL}$, sendo considerado estes resultados dentro dos valores de referência (300-700mg/dL) (Kaneko, 2008). Jain (1993) considerou como melhor indicador de processo inflamatório os níveis de fibrinogênio plasmático quando comparado a avaliação do quadro leucocitário. No presente estudo, os valores de aumentados de fibrinogênio não classificam os animais como enfermos, fato esse que vai de acordo com o descrito por Horadagoda \& Eckersall, (1993) e Kaneko (1997), em que relataram que o fibrinogênio além de outras propriedades, é uma proteína de fase aguda que se encontra em elevadas concentrações em processos inflamatórios.

\subsection{Conclusão}

A suplementação de monensina ou o uso combinado de prebióticos e monensina durante o período de engorda de bovinos Nelore sob efeito do estresse, teve efeito semelhante aos animais que não receberam aditivo com relação ao desempenho e as características de carcaça.

Os parâmetros sanguíneos de bioquímica do sangue de bovinos Nelore após 12 horas de transporte somadas a 12 horas de jejum hídrico e alimentar são alterados, com aumento da concentração plasmática de ureia, creatinina, AST, GGT, proteínas totais, globulinas e CK logo após o dia da viagem, não havendo efeito do uso de prebióticos em associação de monensina. Há alterações no hemograma do sangue dos mesmos animais acima mencionados, com valores elevados no período pós viagem dos parâmetros relacionados ao eritrograma, aos leucócitos, proteínas plasmáticas e fibrinogênio, não havendo efeito do uso de prebióticos em associação de monensina. 


\section{REFERÊNCIAS BIBLIOGRÁFICAS}

ADAMS, D.C.; GALYEAN, M.L.; KIESLING, H.E.; WALLACE, J.D.; FINKNER, M.D. Influence of viable yeast culture, sodium bicarbonate and monensin on liquid dilution rate, rumen fermentation and feedlot performance of growing steers and digestibility in lambs. Journal of Animal Science., 53: 780-789, 1981.

AOAC. Official Methods of Analysis of the Association of Official Analytical Chemists, 15th ed. Association of Official Analytical Chemists Inc., Arlington, Virginia, USA. 1990.

AYRES M.C.C.; BIRGEL E.H.; D’ANGELINO J.L.; BENESI F.J. Avaliação da influência de fatores relacionados ao sexo sobre a variabilidade do eritrograma de zebuínos (Bos indicus, Linnaeus, 1758) da raça Nelore, criados no estado de São Paulo. Revista Brasileira de Saúde e Produção Animal. 1(2):31- 36, 2001.

BARNES, K., SMITH, S.; LALMAN, D. Managing shrink and weighing conditions in beef cattle. Fact sheet ANSI-3257. Oklahoma State University Cooperative Extension Service, 2004.

BARROS FILHO I.R. Contribuição ao estudo da bioquímica clínica em zebuínos da raça Nelore (Bos indicus, Linnaeus 1758) criados no Estado de São Paulo. 1995. 133 f. (Dissertação de Mestrado) - Faculdade de Medicina Veterinária e Zootecnia, Universidade de São Paulo, São Paulo, 1995.

BEILHARZ, R.G.; ZEEB, K. Social dominance in dairy cattle. Applied Animal Ethology, Amsterdam, v. 8, n. 1/2, p.79-97, 1982.

BENATTI, L.A.T. Marcadores fisiológicos do estresse e perfil metabólico de bovinos das raças Curraleiro Pé-Duro, Pantaneiro e Nelore em confinamento experimental. Goiânia. 110f. Tese (Doutorado em Ciência Animal) - Faculdade de Medicina Veterinária e Zootecnia, Universidade Federal de Goiás, 2013.

BENESI, F.J.; COSTA, J.N.; BIRGEL, E.H.; D`ANGELINO, J.L.; AYRES, M.C.C.; FILHO, I. R. B. Leucograma padrão de bovinos da raça Nelore (Bos indicus). Influência de fatores sexuais. Veterinária Notícias, v.8, n.1, p.59-66, 2002.

BITTAR, C.M.M.; SILVA, F.L.M.; PAULA, M.R.; SILVA, J.T.; GALLO, M.P.; OLTRAMARI, C.E., et al. Desempenho e parâmetros sanguíneos de bezerros em sistemas de desaleitamento precoce suplementados com probióticos de bactérias ruminais. Revista Brasileira de Saúde Animal, v. 17, n. 2, p. 249 - 261, 2016.

BÓRNEZ, R.; LINARES, M.B.; VERGARA, H. Haematological, hormonal and biochemical blood parameters in lamb: Effect of age and blood sampling time. Livestock Science, Netherlands, v. 121, p.200-206, 2009.

BROOM， D.M.; GOODE， J.A.; HALL， S.J. G.; LLOYD， D.M.; PARROTT， R. F. Hormonal and physiological effects of a 15-hour Road journey in sheep: comparison with the response to loading, handling and penning in the absence of transport. British Veterinary Journal, v.152, p.593-604, 1996.

BRUM, R.P. Efeito de um aditivo prebiótico no leite e no concentrado sobre o desempenho e aspectos sanitários de bezerros de rebanhos leiteiros. Dissertação (PósGraduação em Zootecnia), Universidade Federal Rural do Rio de Janeiro, Seropédica, RJ. 36p., 2006. 
CARLSON, G.P. Testes de Química Clínica, In: Tratado de Medicina Interna de Grandes Animais: moléstias de equinos, bovinos, ovinos e caprinos São Paulo :Manole. p. 395-23. 1993.

CARROLL, J.A.; FORSBERG, N.E. Influence of stress and nutrition on cattle immunity. Veterenary Clinics Food Animal Practice, v. 23, p. 105-149, 2007.

CHIQUIERI, J.; SOARES, R.T.R.N.; HURTADONERY, V.L.; CARVALHO, E.C.Q.; COSTA, A.P.D. Bioquímica sanguínea e altura das vilosidades intestinais de suínos alimentados com adição de probióticos, prebióticos e antibióticos. Revista Brasileira de Saúde e Produção Animal, v. 8, n. 2, p. 97, 2007.

COFFEY, K.P.; COBLENTZ, W.K.; HUMPHRY, J.B.; BRAZLE F.K. Review: Basic principles and economics of transportation shrink in beef cattle. Professional Animal Science. 17:247-255, 2001.

COLE N.A.; CAMP T.H.; ROWE L.D. JR. Effect of transport on feeder calves. Veterinary Research; 49:178-83, 1988.

CROWDER, M.J.; HAND, D.J. Analysis of Repeated Measures, Chapman \& Hall, London, 1990.

DEAG, J.M. Review of social systems. Applied Animal Ethology, Amsterdam, v. 9, n. 1, p. 83-84, 1982/1983.

DE OLIVEIRA PAES, P. R. et al. O leucograma como indicador de estresse no desmame e no transporte rodoviário de bovinos da raça Nelore. Semina: Ciências Agrárias, p. 305$311,2012$.

DOORNENBAL, H.; TONG, A.K. W; MURRAY N.L. Reference values of blood parameters in beef cattle of different ages and stages of lactation. Canadian, Journal of Veterinary Research, 52 (1988), pp. 99-105

DUFFIELD, T.F.; RABIEE, A.R.; LEAN, I. J. A meta-analysis of the Impact of monensin in lactating dairy cattle. Part1. Metabolic effects. Journal of Dairy Science. V.91, p.13341346. 2008.

ECKERSALL, P.D. Recent advances and future prospects for the use of acute phase proteins as markers of disease in animals. Revue de Médecine Vétérinaire, Toulouse, $v$. 151, p. 577-584, 2000.

EARLEY, B.; DRENNAN M.; O'RIORDAN E.G. The effect of road transport in comparison to a novel environment on the physiological, metabolic and behavioural responses of bulls. Research in Veterinary Science 95, 811-818, 2013.

FAGLIARI, J.J.; McCLENAHAN, D.; EVANSON, O. A.; WEISS, D. J. Changes in plasma protein concentrations in ponies with experimental alimentary laminitis. Journal Veterinary Research, Schaumburg, v.59, n.10, p.1234-1237, 1998.

FRASER, A.F. Comportamiento de los animales de granja. Zaragoza: Acribia. p 291, 1980.

FINCO, D.R. Kidney function. In: KANEKO, J.J., HARVEY, J.W., BRUSS, M.L. Clinical biochemistry of domestic animals. 5.ed. New York: Academic Press. Cap. 17, p. 441-484, 1997.

FOX, D.; SNIFFEN, C.; O'CONNOR, J.; RUSSELL, J.; VAN SOEST, P. A net carbohydrate and protein system for evaluating cattle diets: III. Cattle requirements and diet adequacy. Journal Animal Science. 70, 3578-3596. 1992. 
GAGGiA, F.; MATTARELli, P.; BIAVATI, B. Probiotics and prebiotics in animal feeding for safe food production. Internacional Journal of Food Microbiology, v. 141, p. S15-S28, 2010.

GANDRA, J.R.; RENNÓ, F.P.; SILVA, L.F.P.; FREITAS JÚNIOR, J.E.; MATURANA FILHO, M.; GANDRA, E.R.S.; D’ÂNGELO, L.S.; ARAÚJO, A.P.C. Parâmetros sanguíneos de vacas leiteiras submetidas à diferentes níveis de monensina sódica nas raçãoes. Revista Brasileira de Saúde Produção Animal, v.10, n.1, p.115-128, 2009.

GARCIA, C.C.G.; MENDOZA, M.G.D.; GONZÁLES, M.S.; COBOS, P.M.; ORTEGA, C.M.E.; RAMIREZ, L.R. Effect of a yeast culture (Saccharomyces cerevisiae) and monensin on ruminal fermentation and digestion in sheep. Animal Feed Science Technology, 83: 165-170, 2000.

GHOSH, S.; MEHLA, R.K. Influence of dietary supplementation of prebiotics (mannanoligosaccharide) on the performance of crossbred calves. Tropical animal health and production, v. 44, n. 3, p. 617-622, 2012.

GIBSON, G.R.; ROBERFROID, M.B. Dietary modulation of the human colonic microbiota: Introducing the concept of prebiotics. Journal of Nutrition. 125:1401-1412, 1995.

GOMES, R.C.; LEME P.R.; SILVA S.L.; ANTUNES M.T.; GUEDES C.F. Carcass quality of feedlot finished steers fed yeast, monensin, and the association of both additives. Arquivo Brasileiro de Medina Veterinária e Zootecnia Zootec. ;61:648-654; 2009.

GOMES, R.C.; ANTUNES, M.T.; SILVA, S.L.; LEME, P.R. Desempenho e digestibilidade de novilhos zebuínos confinados recebendo leveduras vivas e monensina. Archivos de Zootecnia, v.60, p.1077-1086, 2011.

GONZÁLEZ, F.H.D.; SCHEFFER, J.F. Perfil sanguíneo: ferramenta de análise clínica, metabólica e nutricional. In: GONZÁLEZ, F.H.D. (ed.). Doze leituras em bioquímica clínica veterinária. Porto Alegre: Universidade Federal do Rio Grande do Sul. v. 1, p. 3045, 2018.

GOODRICH, R.D.; GARRETT, J.E.; GAST, D.R.; KIRICK, M.A.; LARSON, D.A.; MEISKE, J.C. Influence of monensin on the performance of cattle. Journal of Animal Science, v.58, p.1484-1498, 1984.

GOULART, R.S. et al. Effects of source and concentration of neutral detergent fiber from roughage in beef cattle diets on feed intake, ingestive behavior, and ruminal kinetics. Journal of animal science, v. 98, n. 5, p. skaa107, 2020.

HALL, M.B. Determination of starch including maltooligosaccharides, in animal feeds: Comparison of methods and a method recommended for AOAC collaborative study. Journal Association of Official Analytical Chemists Int. 92, p. 42-49, 2009.

HORADAGODA, A.; ECKERSALL, P.D. Purification and qualicative measurement of bovine serum amyloid-A. Research in Veterinary Science, v. 55, p. 317- 325, 1993.

JAIN, N.C. Schalm's veterinary hematology. 4 th ed. Philadelphia (PA): Lea; Febiger; p.1221, 1986.

JAIN, C.N. Essential of veterinary hematology. Philadelphia: Lea \& Febiger. p 417, 1993. 
JONES, M.L.; ALLISON, R.W. Evaluation of the ruminant complete blood cell count. Veterinary Clinics Food Animal Practice, v. 23, p. 377-402, 2007.

JORGE, A.M.; FONTES, C.A.A.; PAULINO, M.F. et al. Desempenho produtivo de quatro raças zebuínas, abatidos em três estádios de maturidade. 2. Características da carcaça. Revista Brasileira de Zootecnia, v.28, n.2, \p.381-387, 1999.

KANEKO, J.J. Clinical biochemistry of domestic animals. 4. ed., London: Academic Press, 932 p, 1989.

KANEKO, J. J.; HARVEY, J. W.; BRUSS, M. L. Clinical biochemistry of domestic animals. 6th ed. San Diego: Academic Press. 932p, 1997.

KANEKO, J. J.; HARVEY, J. W.; BRUSS, M. L. Clinical biochemistry of domestic animals. 6th ed. San Diego: Academic Press. 932p,1997c.

KANEKO, J. J.; HARVEY, J. W.; BRUSS, M. L. Clinical biochemistry of domestic animals. 5th ed. San Diego: Academic Press. 916p, 2008.

KNOWLES, T.G. et al. Effects on sheep of transport by Road for up to 24 hours. Veterinary Record, London, v.136, p.431-438, 1995

KNOWLES, T. G.; WARRIS, P.D.; BROWN, S.N.; KESTIN, S.C.; EDWARDS, J.E.; PERRY, A.M.; WATIKINS, P.E.; PHILLIPIS, A.J. Effects of feeding, watering and resting intervals on lambs transport by road and ferry to France. Veterinary Record, London, v.139, p. 335-339, 1996.

KNOWLES, T.G. A review of the Road transport of slaughter sheep. Veterinary Record, London, v.143, p. 212-219, 1998.

KONONOFF, P.J.; HEIRINCHS, A.J.; LEHMAN, H.A. The effect of corn silage particle size on eating behavior, chewing activities and rumen fermentation on lactating dairy cows. Journal of Dairy Science, Champaing, v. 86, p. 3343-3353, 2003.

KRAMER, J.W. Normal hematology of cattle, sheep, and goats. In: Feldman BF, Zinkl, J.G., Jain, N.C., editors. Schalm's veterinary hematology. 5th edition. Philadelphia: Lippincott Williams \& Wilkins; p. 1075-84, 2000.

KUSS, F.; RESTLE, J.; MENEZES, L.F.G.; ALVES FILHO, D.C; BRONDANI, I.L.; ARBOITTE, M.Z.; MOLETTA, J.L. Características da carcaça de vacas de descarte terminadas em confinamento recebendo dietas com ou sem adição de monensina. Ciência Animal Brasileira, Goiânia, v. 10, n. 1, p. 83-90, 2009.

LEE, J.A; ROUSSEL J.D.; BEATTY J.F. Effect of temperature season on bovine adrenal cortical function, blood cell profile, and milk production. Journal of dairy Science, Champaign, v. 59, n. 1, p. 104-108, 1974.

LINFORD, R.L. Laminite (aguamento). In: SMITH, B. P. Tratado de medicina interna de grandes animais. v. 2. São Paulo: Manole, 1738 p, 1994.

MAEKAWA, M.; BEAUCHEMIN, K.A.; CHRISTENSEN, D.A. Chewing activity, saliva praduction and ruminalpH of primiparous and multiparous lactating dairy cows. Journal os Dairy Science, Savoy, v. 85, p. 1176-1182, 2002,

MAGLIOCCA, F.C.; SILVEIRA, A.C.; FURLAN, L.R. et al. Efeito da niacina e da monensina sódica no desempenho de novilhos em confinamento. Pesquisa Agropecuária Brasileira, v.29, n.6, p.983-988, 1994. 
MARIANI, T.M. Suplementação de anticorpos policlonais ou monensina sódica sobre comportamento ingestivo e desempenho de bovinos Brangus e Nelore confinados. Dissertação de Mestrado, Universidade Estadual Paulista Faculdade De Medicina Veterinária e Zootecnia, Campus De Botucatu 2010.

MATARAZZO, S.V. Eficiência do sistema de resfriamento adiabático evaporativo em confinamento do tipo freestall para vacas em lactação. Tese de doutorado - Escola Superior de Agricultura "Luiz de Queiroz” Piracicaba - Universidade de São Paulo, 2004.

MATHEW, A.G.; SUTTON, A.L.; SCHEIDT, A.B.; PATTERSON, J.A.; KELLY, D.T.; MEYERHOLTZ, K.A. Effect of galactan on selected microbial populations and $\mathrm{pH}$ and volatile fatty acids in the ileum of the weanling pig. Journal of Animal Science, v. 71, n. 6, p. 1503-1509, 1993.

MEYER, D.J.; HARVEY, J.W. Veterinary laboratory medicine: interpretation \& diagnosis. 2 ed. Philadelphia:Sauders, p351, 2004.

MILLEN, D.D.; RONCHESEL, J.R.; PARRA, F.S.; PACHECO, R.D.L.; MARTINS, C.L.; ARRIGONI, M.D.B. Anticorpos policlonais em dietas com alta inclusão de concentrado para bovinos confinados. Ciência Rural, v.43, p.1660-1667, 2013.

MIR, Z.; MIR, P.S. Effect of the addition of live yeast (Saccharomyces cerevisiae) on growth and carcass quality of steers fed highforage or high grain diets and on feed digestibility and in situ degradability. Journal Animal Science, 72: 537- 545, 1994.

MORAIS, M.G.; RANGEL, J.M.; MADUREIRA, J.S.; SILVEIRA, A.C. Variação sazonal da bioquímica clínica de vacas aneroladas sob pastejo contínuo de Brachiaria decumbens. Arquivo Brasileiro de Medicina Veterinária e Zootecnia 52:98-104, 2000.

MÜLLER, L. Normas para avaliação de carcaças e concurso de carcaças de novilhos. Santa Maria: Universidade Federal de Santa Maria. p 31, 1987.

ODORE, R.; D'ANGELO, A., BADINO, P., BELlinO, C., PAGLIASSO, S., \& RE, G. Road transportation affects blood hormone levels and lymphocyte glucocorticoid and $\beta$ adrenergic receptor concentrations in calves. The Veterinary Journal, v. 168, n. 3, p. 297303, 2004.

OLIVEIRA, M.V.M.; LANA, R.P.; JHAM, G.N.; PEREIRA, J.C.; PÉREZ, J.R. O.; VALADARES FILHO, S. C. Influência da monensina no consumo e na fermentação ruminal em bovinos recebendo dietas com teores baixo e alto de proteína. Revista Brasileira de Zootecnia, v.34, n.5, p.1763-1774, 2005.

PALHARES, J.C.P. Comunicado técnico 1021: Consumo de água na produção animal. ISSN 1981-206X; São Carlos, SP Técnico, novembro, 2013.

PAYNE, J.M.; PAYNE, S. The Metabolic Profile Test. Oxford University Press. New York, 1987.

PEREIRA, M.C.S. Efeitos da dosagem de monensina sódica sobre o desempenho produtivo, comportamento ingestivo, saúde ruminal e características de carcaça em bovinos Nelore confinados. - Dracena : [s.n.], 2014. 68 f. Dissertação (Mestrado em Ciência e Tecnologia Animal) - Universidade Estadual Paulista, Campus Experimental de Dracena/Campus de Ilha Solteira. Dracena/Ilha Solteira, SP, 2014.

QUIGLEY III, J. D.; KOST, C. J.; WOLFE, T. A. Effects of spray-dried animal plasma in milk replacers or additives containing serum and oligosaccharides on growth and health of calves. Journal of dairy science, v. 85, n. 2, p. 413-421, 2002. 
MATHEUS, N.; RAMÍREZ, F.; SALAZAR, C.; LEONARDI, F; BRAVO, H.. Relación albumina:globulina plasmáticas en tres épocas Del año en vacas de la raza Carora Del estado Lara-Venezuela. In: CONGRESSO NACIONAL DE BUIATRIA, Vera Cruz. Anales...Vera Cruz, 2001.

RIBEIRO, F.; MENDES, J.; FRANCISCO, C.; CASTILHOS, A.; PARIZ, C. Y.; SILVA, M. Simbióticos e monensina sódica no desempenho e na qualidade da carne de novilhas mestiças Angus confinadas. Pesquisa Agropecuária Brasileira, 50(10), 958-966, 2015.

SANTOS, T.N.S.; CASTRO, V.; SOARES, A.L.; OBA, A.; SHIMOKOMAKI, M. Prebióticos, probióticos e simbióticos na nutrição dos animais (Revisão). Revista Eletrônica Nutritime, v.5, n 3, p.573-576 Maio/Junho 2008.

SAUBERLICH, H.E. Laboratory Tests for the Assessment of Nutritional Status. [S. 1.]: CRC press. v. 21, 1999.

SCHALM, O.M.; JAIN, N.C. Veterinary Hematology. $4^{\text {th }}$ ed. Philadelphia: Lea \& Fabiger, 1986.

SCHALM, W.; JAIN, N.C.; CARROLL, E.J. Hematologia veterinária. Buenos Aires: Hemisferio Sur, 856 p, 1981.

SCHELLING, G.T. Monensin mode of action in the rumen. Journal of Animal Science, 58(6), 1518-1527, 1984.

SELF, H.L.; GAY, N. Shrink during shipment of feeder cattle. Journal Animal Science. 35:489-94, 1972.

SEVELIUS, E.; ANDERSSON, M. Serum protein eletrophoresis as a prognostic marker of chronic liver disease in dogs. Veterinary Record, London, v. 137, p. 667, 1995.

SILVA, E.B.; FIORAVANTI, M.C. S.; SILVA, L.A. F.; ARAÚJO, E.G.; MENEZES, L. B. Característica leucocitária, relação albumina/globulina, proteína plasmática e fibrinogênio de bovinos da raça Nelore, confinados e terminados a pasto. Ciência Rural, Santa Maria, v. 38, n. 8, p. 2191-2196, 2008a.

SMITH, G.S. Neutrophils. In: FELDMAN, B.; ZINKL, J.; JAIN, N.C. Schalm's veterinary hematology. 5. ed. Philadelphia: Lippincott Williams \& Wilkins. cap. 46, p. 281-296, 2000.

SMITH, R.A. Impacto f disease on feedlot performance: A Review. Journal of Animal Science, v. 76, p. 272-274, 1998.

SWANSON, J.C.; MORROW-TESCH, J. Cattle transport: Historical, research, and future perspectives. Journal of Animal Science, v. 79, (E. Suppl.), p. E102-E109, 2001.

TADICH, N.; GALLO, C.; BRITO, M.L.; BROOM D.M. Effects of weaning and $48 \mathrm{~h}$ transport by Road and ferry on some blood indicators of wealfare in lambs. Livestock Science, v. 121. P.132-136, 2009.

TEDESCHI, L.O.; FOX, D.G.; TYLUTKI, T.P. Potential environmental benefits of ionophores in ruminant diets. Journal of Environmental Quality., 31, pp. 1591-1602, 2003.

UYENO, Y.; SHIGEMORI, S.; SHIMOSATO, T. Effect of probiotics/prebiotics on cattle health and productivity. Microbes and Environments. v. 30, p.126-132, 2015.

VAN SOEST, P.J. Collaborative study of acid-detergent fiber and lignin. Journal AOAC Int. v.56, p. 781-784, 1973. 
VAN SOEST, P.J.; ROBERTSON, J.B.; LEWIS, B.A. Methods for dietary fiber, neutral detergent fiber, and non-starch polysaccharides in relation to animal nutrition. Journal of Dairy Science, Savoy, v. 74, p. 3583-3597, 1991.

Warriss P.D. Antemortem factors influencing the yield and quality of meat from farm animals. In: Quality and Grading of carcasses of Meat Animals ed. S.D. Morgan Jones. CRC Press, Boca Raton, Ch 1, pp. 1-15, 1995.

WEISS, D.J.; PERMAN, V.P. Assessment of the hematopoietic system in ruminants. Veterinary Clinics of North America: Food Animal Pravtice, Philadelphia, v.8, n.2, p.411-429, 1992.

WILES, P.G.; GRAY, I.K.; KISSLING, R.C. Routine analysis of proteins by Kjeldahl and Dumas methods: review and interlaboratory study using dairy products. Journal AOAC Int, v. 81, p. 620-632, 1998.

ZANINE, A.M.; OLIVEIRA, J.S.; SANTOS, E.M. Importância, uso, mecanismo de ação e retorno econômico dos ionóforos na nutrição de ruminantes. Revista Científica Eletrônica de Medicina Veterinária e Zootecnia de Garça, n.6, p.1-18, jan., 2006.

ZHANG, N.; JU, Z.; ZUO, T. Time for food: The impact of diet on gut microbiota and human health. Nutrition. 2018; 51-52 80-85

ZINN, R.A.; PLASCENCIA, A.; BARAJAS, R. Interaction of forage level and monensin in diets for feedlot cattle on growth performance and digestive function. Journal Animal Science, 72: 2209- 2215, 1994. 